\title{
Áreas cementeriales y registros funerarios altomedievales y de época hispano-musulmana en el yacimiento de la Orden-Seminario (Huelva)
}

\author{
Cemetery areas and funeral records of Early Medieval Period and Hispanic- \\ Muslim Era in La Orden-Seminario site (Huelva)
}

José Manuel Beltrán Pinzón ${ }^{1}$

Cristóbal Ignacio Batanero Martín ${ }^{2}$

Recibido: 13/11/2018 - Enviado a Evaluación: 23/11/2018 - Aprobado: 25/03/2019

\section{RESUMEN}

En el presente artículo se propone una aproximación a la ocupación de época hispano-musulmana en el yacimiento de La Orden-Seminario (Huelva), de acuerdo con la información arqueológica y paleoantropológica obtenida en la excavación de una necrópolis perteneciente a una pequeña comunidad rural. A partir de los últimos restos de la ocupación visigoda, se ha podido determinar una evolución de la necrópolis en dos fases, entre las que se desarrolla un episodio de uso agrícola que tiene como expresión material la instalación de un campo de silos de almacenamiento, cuyo material arqueológico nos aporta elementos suficientes de contrastación cronológica. El comportamiento poblacional documentado viene a revelar las condiciones de vida de los núcleos rurales de la Huelva islámica y su evolución histórica a lo largo de los siglos VIII al XII, permitiéndonos plantear las formas y los ritmos con que se produjo la islamización religiosa de las comunidades rurales emplazadas en el entorno de la ciudad.

Palabras clave: Necrópolis, Periodo medieval-islámico, Islamización, Huelva, España.

\section{INTRODUCCIÓN}

Las evidencias funerarias de época hispano-musulmana que presentamos en este trabajo representan, por distintas razones que expondremos, una de las manifestaciones arqueológicas de época medieval de mayor notoriedad atestiguadas en el conocido por la investigación actual como yacimiento de La

\begin{abstract}
This article exposes an approximation to La Orden-Seminario's archaeological site occupation during Hispanic-Muslim Era, according to archaeological and paleoanthropological evidence collected in an excavation at a small rural necropolis. From the last visigothic population remains, it has been possible to figure out the necropolis evolution in two phases that were interrupted by an episode of agricultural activity whose storage structures provided enough evidence to establish a chronological reference frame. Documented population behaviour reveals life conditions in rural communities and their historical evolution throughout VIII to XII centuries, what gives us the chance to consider the shape and the flow of the islamization process among the rural communities in that zone.
\end{abstract}

Key words: Necropolis, Medieval Islamic Era, Islamization, Huelva, Spain.

Orden-Seminario. Este yacimiento, descrito en sus aspectos generales en anteriores estudios (GONZÁLEZ et alii, 2008: pp. 1-7; VERA et alii, 2010: pp. 202-207), conforma un extenso solar rectangular de 23 hectáreas de superficie, delimitado y protegido administrativamente en la actualidad, el cual se encuentra situado en el límite noroeste de la ciudad de Huelva coincidiendo urbanísticamente con los terrenos

1. Biblioteca Universitaria, Universidad de Huelva.jmanuel.beltran@biblio.uhu.es

2. Ánfora Grupo, Avda. Portugal, n² 2, A, 21001 Huelva. batybatanero@gmail.com 


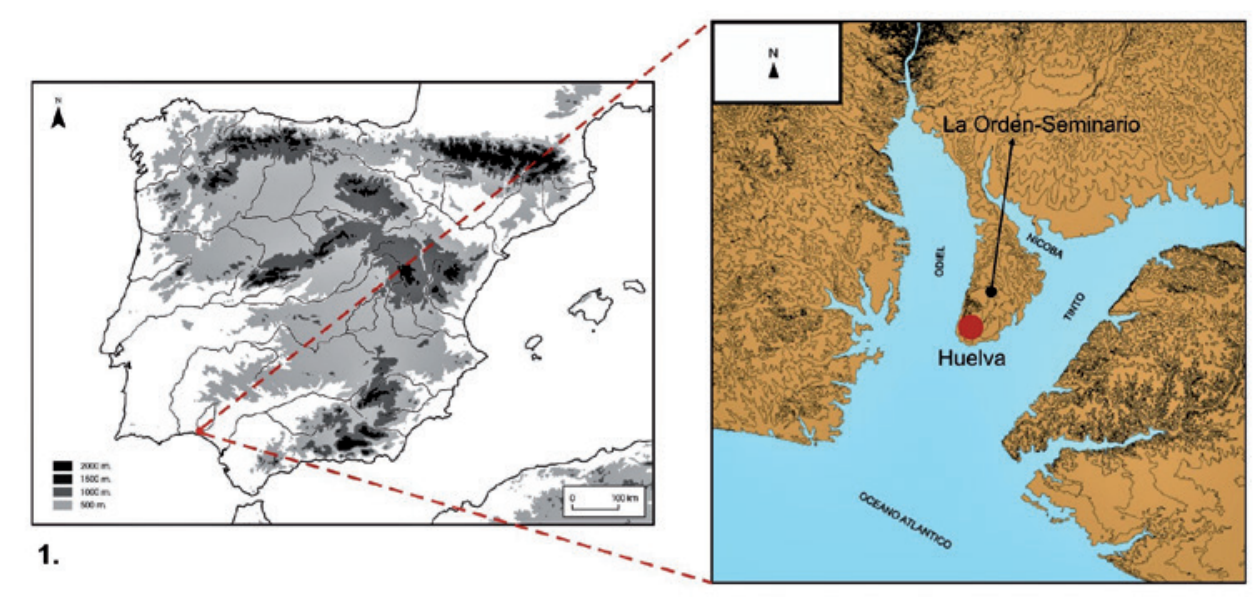

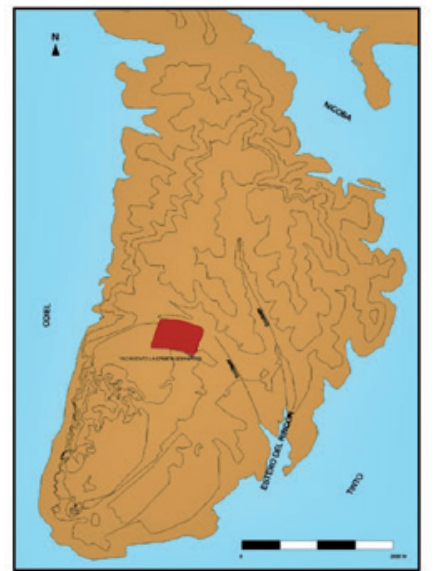

2.

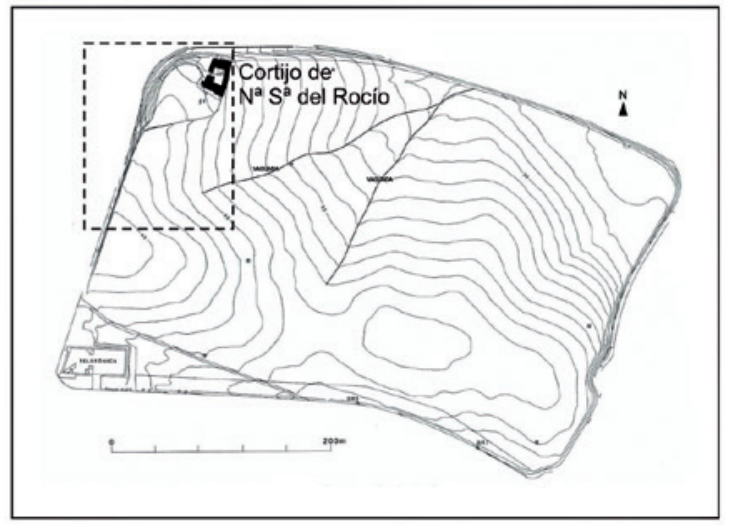

3.

Fig. 1. 1. Localización de Huelva y del paleoestuario del Tinto-Odiel en el contexto de la Península Ibérica. 2. Situación del yacimiento de La Orden-Seminario en el marco geográfico de la península del estuario del Tinto-Odiel. 3. Delimitación del yacimiento y área principal de distri-

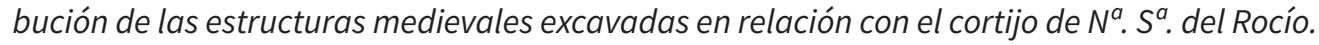

comprendidos en el Plan Parcial $n^{\circ} 8$. El yacimiento está incluido en el sector B-3 "Santa Marta-La Orden" de la Zona Arqueológica de la capital onubense, cuyas excavaciones han sacado a la luz varios miles de estructuras arqueológicas que testimonian una ocupación continuada desde el Neolítico final hasta época contemporánea (Fig. 1).

La zona de enterramiento islámico documentada, con una extensión de unos $536 \mathrm{~m}^{2}$, se localiza en el sector noroccidental del yacimiento, muy próxima al antiguo cortijo de Nuestra Señora del Rocío y adyacente al cantil que lo delimita por el lado oeste (Fig. 1). To- pográficamente, la necrópolis se sitúa en la ladera septentrional de una de las pequeñas elevaciones amesetadas que forman la finca, a una cota de 42 m.s.n.m., y aparece flanqueada al sur por un marcado cauce de escorrentía superficial. A nivel territorial, las ocupaciones antigua y medieval de la Orden-Seminario se enmarcan en un ámbito periurbano caracterizado por un poblamiento rural compuesto por pequeños núcleos habitacionales de carácter agrícola (villae y qurā), cuyo alcance histórico está siendo puesto en evidencia por la investigación arqueológica reciente (CAMPOS, 2009: pp. 138-154; VIDAL et alii, 2013), si bien los restos materiales de este poblamiento periférico 
son conocidos de antiguo 3 . Con todo, la necrópolis de época islámica de La Orden-Seminario, con un total de treinta y dos tumbas excavadas, distribuidas en dos fases cronológicas, viene a ser la mayor área cementerial de rito islámico registrada hasta el momento en la provincia de Huelva, al tiempo que constituye una aportación fundamental para el estudio de la historia medieval de la propia capital, sobre todo si tenemos en cuenta que son prácticamente inexistentes los datos que disponemos sobre las maqābir de la Wilba musulmana ${ }^{4}$.

La primera referencia sobre la ocupación medieval en la zona objeto de estudio se produjo en 1997, fecha en la que, con motivo de la realización de los trabajos de urbanización en el acceso a la autovía de circunvalación, quedaron al descubierto un enterramiento y diversas estructuras de almacenamiento de tipo silo. La intervención arqueológica de urgencia llevada a cabo al año siguiente constató la presencia de un silo cuyos materiales asociados permitieron su adscripción al periodo islámico (PÉREZ, VIDAL y DE HARO, 2001: p. 380). A partir de 2005, los trabajos arqueológicos ejecutados por la empresa Ánfora GIP en el viario del Plan Parcial n ${ }^{\circ} 8$ tuvieron como resultado inmediato la delimitación y caracterización del yacimiento y su inclusión dentro de la ampliación del sector B-3 de la Zona Arqueológica, circunscrito a raíz de esa primera intervención de 1998 al vértice noroeste del solar.

A fecha de hoy y a tenor de los datos conocidos hasta el momento, se comprueba que el poblamiento medieval se ciñe prácticamente al sector más occidental del yacimiento y especialmente al ángulo noroeste, zona donde se observa más nítidamente la sucesión de los diversos episodios de ocupación y de uso que transcurren desde un momento impreciso de la Antigüedad tardía hasta el siglo XII. Mención especial merece la necrópolis de época visigoda, cuyas evidencias han sido analizadas en otro trabajo (BATANERO, BELTRÁN y VERA, 2016). Al margen de los registros funerarios, son también de gran interés las estructuras que testifican el aprovechamiento agrícola del entorno, cuya proyección en el terreno dibuja una abigarrada concentración de silos o dispositivos subterráneos de almacenamiento y de otra índole, aún por valorar, cuyos contenidos materiales posibilitan un acercamiento a la periodización y definición de dicha explotación económica. Las relaciones de corte y de antero-posterioridad que se establecen entre estas estructuras y las propias tumbas, aunque bastante ocasionales, nos han permitido proponer dataciones relativas más precisas para los dos conjuntos de enterramientos documentados, una circunstancia que ha facilitado su encuadre cronológico en periodos más o menos amplios, dado que, como es habitual en los sepulcros islámicos, la ausencia de ajuares dificulta en gran medida su datación.

La documentación arqueológica de la que deriva este estudio procede del conjunto de intervenciones arqueológicas preventivas desarrolladas por la empresa Ánfora GIP5, con la que la Universidad de Huelva suscribió dos contratos de investigación sucesivos de asesoría científica y apoyo técnico; para el estudio

\footnotetext{
3. Según la documentación de la Real Academia de la Historia, reseñada y estudiada por J. L. Carriazo (2006), se hallaron en 1885 en el paraje denominado de El Torrejón -actual barriada de Huelva limítrofe con el yacimiento de La Orden-Seminario- varias tumbas romanas y un tesorillo de monedas andalusíes, así como restos de edificios que este autor pone en relación con explotaciones agrícolas del tipo del Cabezo de la Almagra (CARRIAZO, 2006: p. 212), un emplazamiento cercano a la zona de La Orden-Seminario (VIDAL et alii, 2013).

4. Se tiene constancia de la existencia de una necrópolis árabe descubierta a principios del siglo XX en el entorno de la calle Tres de Agosto de la capital onubense, dos de cuyas lápidas se encuentran depositadas en el Museo Provincial de Huelva (DÍAZ, 1921; GÓMEZ y CAMPOS: 2001, p. 125). Los epitafios de las estelas funerarias conservadas -šahïd-sitúan estos enterramientos en los siglos XIV-XV, por lo que se trataría de un cementerio mudéjar (DÍAZ, 1921: pp. 197-198).

5. Echevarría Sánchez, A. y González Batanero, D. (2007): Memoria Final de la Intervención Arqueológica de Urgencia en el Sector 8 del Plan Parcial "Seminario" de Huelva, Huelva, Delegación Provincial de Cultura. Inédito.

González Batanero, D. y Echevarría Sánchez, A. (2008): Memoria Preliminar de la Intervención Arqueológica Preventiva en el Sector 8 de Huelva, Seminario, Huelva, Delegación Provincial de Cultura. Inédito.

González Batanero, D. (2015): Memoria. Intervención Arqueológica Preventiva en el Sector 8 del PGOU de Huelva yacimiento La Orden-Seminario, Huelva, Delegación Provincial de Cultura. Inédito.
} 
antropológico nos hemos basado en la información contenida en sendos informes técnicos elaborados por la investigadora I. López Flores (2006; 2009) sobre los restos humanos registrados en dichas actuaciones. Por otro lado, el artículo que aquí se presenta forma parte del Trabajo Fin de Master presentado en la Universidad de Huelva por uno de los firmantes durante el curso académico 2012-20136.

\section{LA INFORMACIÓN CRONOESTRATIGRÁFICA: FASES DE LA OCUPACIÓN MEDIEVAL}

\subsection{Los contextos arqueológicos del área de actuación}

Los contextos correspondientes al periodo medieval se localizan en la mitad occidental del yacimiento hasta la vaguada que separa las dos elevaciones amesetadas que lo forman, registrándose en el extremo noroeste de este sector una alta concentración de evidencias que responden a tipologías morfológicas heterogéneas, así como a usos y funciones diversificadas?. Se nos presentan masivamente imbricadas en una secuencia estratigráfica y temporal que abarca distintas fases a lo largo de varios siglos, la cual podría arrancar, según estudios iniciales, en el periodo tardorromano, con continuidad hasta un momento bajomedieval. Según la información preliminar que poseemos, las estructuras medievales excavadas pueden ser a priori categorizadas tipológicamente como silos de almacenamiento, zanjas de delimitación agrícola, sistemas de cultivos consistentes en plantíos de árboles (alcorques) y estructuras semisubterráneas de grandes proporciones susceptibles de identificar con espacios habitacionales (GONZÁLEZ et alii, 2008: pp. 17-19), amén de los enterramientos que forman parte de los cementerios objeto de este estudio y los pertenecientes a la necrópolis de época visigoda ubicada a escasos metros de los anteriores (Fig. 2).

Las mayores concentraciones de este tipo de estructuras se documentan, con una distribución espontánea y escasamente planificada, en dos áreas específicas de este sector del yacimiento: una agrupación menos numerosa se dispone sobre la cima de la loma occidental, donde encontramos que muchas de ellas han sido afectadas por la prolongación de la Avenida Santa Marta en dirección al actual cementerio, quedando cortadas en el talud que delimita el sector por el oeste; por otro lado, la ladera noreste de ese mismo cerro, en dirección al cortijo de Nuestra Señora del Rocío, alberga el conjunto más abundante y abigarrado, el cual presenta, en algunos casos, relaciones de corte y superposición con enterramientos de ambas fases de la necrópolis islámica (Fig. 1.3).

Del cúmulo de estructuras de almacenamiento tan solo podemos avanzar, por los datos de campo y a falta de un estudio pormenorizado de las estratigrafías y ergología resultantes, que son estructuras de gran tamaño y profundidad (más de dos metros algunas de ellas), de planta circular y perfiles por lo general de sección cilíndrica o troncocónica, cuya amortización indica un reaprovechamiento como basureros o escombreras en su mayor parte, algunas de las cuales contienen materiales constructivos de acarreo, en algún caso acopiados para su posterior uso, procedentes de un asentamiento romano cercano. En el interior de estas estructuras siliformes se encuentran representados, junto a una cultura material de clara adscripción islámica, una importante cantidad de materiales romanos amortizados (moneda reutilizada como colgante, capitel corintizante, fuste de columna y pondera, entre otros materiales destacados) (Figs. 7.1 y 7.4), grandes fragmentos líticos utilizados en la molturación de cereales y restos

\footnotetext{
6. Batanero Martín, C. (2013): Las necrópolis tardoantiqua e islámicas del yacimiento de La Orden-Seminario de Huelva. Trabajo fin de máster. Máster interuniversitario en Arqueología y Patrimonio: ciencia y profesión. Director: Prof. Dr. D. Juan Aurelio Pérez Macías, Profesor Titular de Arqueología, Departamento de Historia I. Facultad de Humanidades, Universidad de Huelva. Inédito.

7. A efectos de localización espacial, el terreno en cuestión ha recibido distintas denominaciones en relación con la zonificación efectuada en los trabajos de excavación como ajuste a la urbanización proyectada: de este a oeste, "Vial 2B", "Zona Verde" y "Talud”.
} 


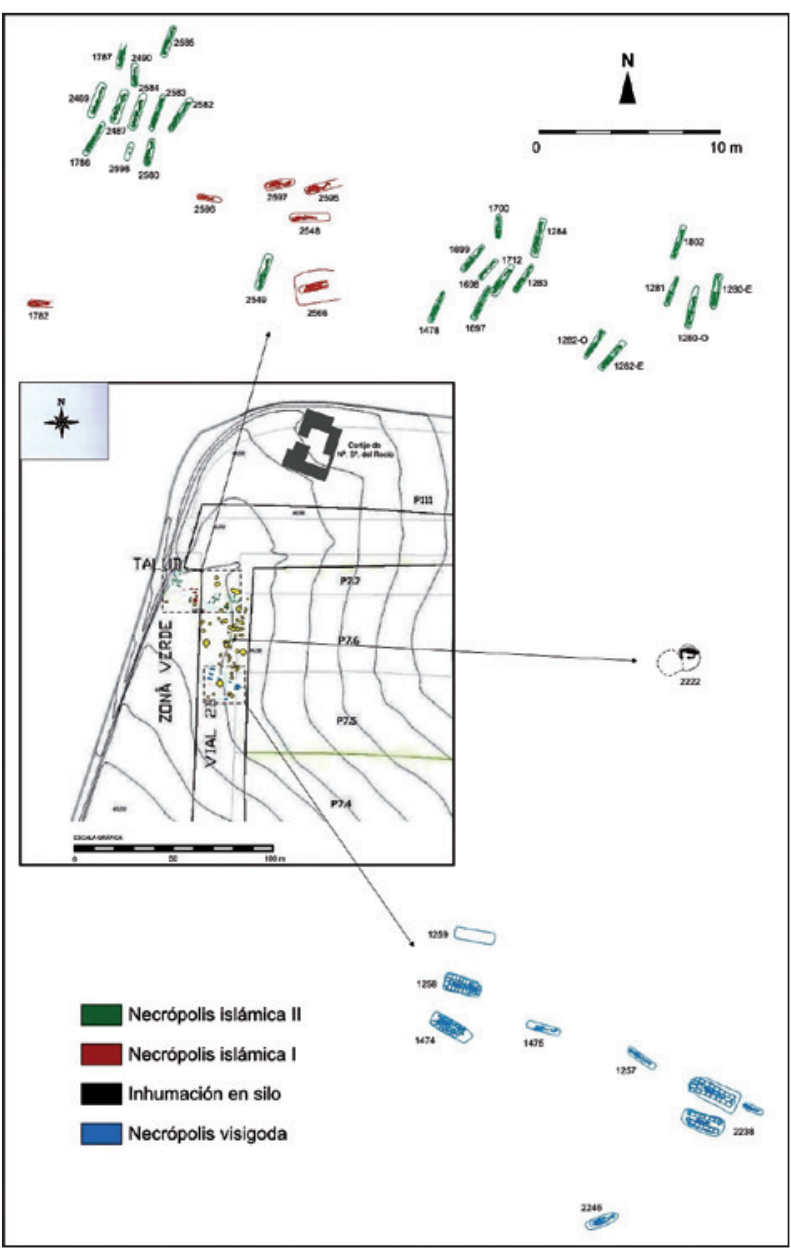

Fig. 2. Plano de las necrópolis visigoda e islámica documentadas en el sector NO del yacimiento de La Orden-Seminario (entre ambas se localiza el silo con la inhumación anómala).

de fauna terrestre (bóvidos) y marina (conchas de moluscos bivalvos) como subproductos del consumo alimentario.

Dada la existencia del cortijo contemporáneo en el mismo extremo noroeste de la finca y la concentración de estructuras medievales en su entorno, además de la presencia de evidencias y materiales romanos reaprovechados en el interior de los silos, queremos de nuevo establecer de manera provisional el paralelismo entre esta ubicación y la cercana del ya desaparecido cortijo del Cabezo de la Almagra, donde se documentó en su momento un cortijo moderno-contemporáneo que reaprovechaba estructuras y materiales medievales islámicos que a su vez se asentaban sobre los restos constructivos de una villa romana (VIDAL et alii, 2013). Todo parece indicar que el esquema de uso continuado de un asentamiento eminentemente agrícola que perdura a lo largo del tiempo, aunque con sus lógicos hiatos, desde época romana hasta la contemporaneidad es más que plausible para esta zona del yacimiento, si bien tan solo es posible establecer la relación entre las estructuras islámicas medievales y los materiales romanos reutilizados, puesto que la zona concreta de la construcción contemporánea, una vez derribada la misma en una primera fase de las obras de urbanización, no ha sido estudiada ni excavada por el momento. En este sentido, la ubicación de un posible asentamiento rural en este sector, en cualquier caso testimoniada por la alta densidad de subestructuras romanas y medievales y la existencia de espacios funerarios asociados, vendría reforzada asimismo por el hecho de estar localizado en el borde mismo de una de las vías romanas de acceso a la ciudad de Onoba, cuyo trazado más probable, según la planimetría antigua, ceñiría precisamente el flanco oeste del yacimiento, coincidiendo a grandes rasgos con la actual Avenida Santa Marta (RUIZ, 1998: pp. 79-80, f. 8).

En este contexto rural, alejado de la antigua ciudad romana, y al amparo del paso de la vía, se ubica la necrópolis de época visigoda junto con otras manifestaciones tardoantiguas, algunas de las cuales, entre ellas la estructura 2222/E-1, que contiene una inhumación en contexto no funerario, caracterizan a nivel material la transición hacia el mundo islámico, dejando entrever la continuidad en el uso del espacio, tanto económico como funerario, y la evolución de una comunidad local involucrada en un posterior proceso de islamización.

Estratigráficamente, los silos y otras subestructuras del área septentrional quedan enmarcados mayoritariamente entre los dos conjuntos de enterramientos que definen las fases de la necrópolis islámica. A través de las 


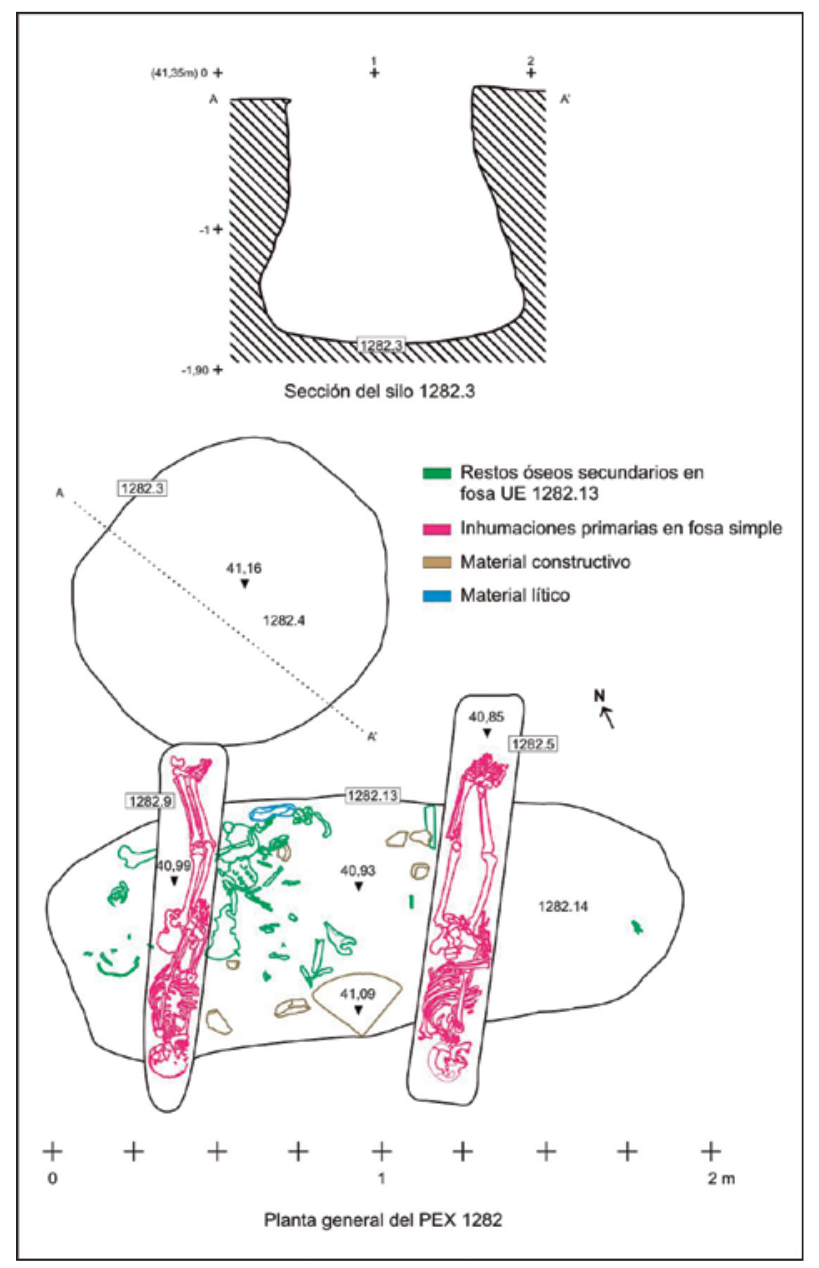

Fig. 3. Contextos superpuestos integrados en el PEX 1282.

relaciones de corte establecidas entre las sepulturas y aquellas otras evidencias es posible perfilar una secuencia temporal que nos permite aquilatar cronologías relativas para las dos agrupaciones de tumbas diferenciadas.

Al primero de los conjuntos de tumbas, con orientación este-oeste, se les superponen dos estructuras de diferente morfología con materiales islámicos. Las estructuras involucradas son las siguientes:

- PEX8 1782: comprende una sepultura en fosa simple (UE 1782.5) y una estructura de perfil siliforme (UE 1782.3). La tumba se encuentra cortada por el silo en su extremo este, por lo que en esta zona la estructura funeraria aparece completamente seccionada, habiendo desaparecido las extremidades inferiores del individuo inhumado. El silo presenta planta circular y paredes acampanadas, con diámetro de 0,81 m y profundidad de 0,68 m. Contiene dos rellenos (UUEE 1782.4 y 1782.9) con abundante material constructivo de desecho (ladrillos, adobes y fragmentos de pizarra), restos de fauna y abundantes fragmentos cerámicos.

- PEX 2590: constituye un amplio rebaje del terreno de planta irregular y sección en "U" (UE 2590.3), con dimensiones máximas de 5,65 × 4,32 m y una profundidad conservada de 0,26 m, bajo el que subyacen las sepulturas 2548, 2595 Y 2597, afectándolas en distintos grados. Comprende un único nivel de relleno (UE 2590.4) con materiales secundarios de vertido y una pequeña área de combustión de planta circular (UUEE 2590.5 y 2590.6$)$ que afecta particularmente a la tumba 2548.

Para esta primera fase de la necrópolis, resulta de especial interés, en base a la consecución de un término post quem, la relación existente entre la tumba 2566 (UUEE 2566.4 y 2566.5) y la fosa de sección acampanada a la que corta (UE 2566.11), cuyos escasos materiales cerámicos apuntan hacia una fase avanzada de la tardoantigüedad (Fig. 10).

En lo que se refiere a la fase II de la necrópolis, a la que se adscribe el conjunto de sepulcros con orientación suroeste-noreste, constatamos la relación de superposición de tres de las tumbas respecto a estructuras siliformes y en fosa subyacentes, correspondiendo estas últimas, a juzgar por los materiales cerámicos que contienen, al mismo episodio de actividad que las estructuras sobrepuestas a los enterramientos de la fase I. Las estructuras en cuestión son las que siguen:

8. "Punto de Excavación”, unidad de registro que identifica a una o a varias evidencias estructurales interrelacionadas estratigráficamente. 


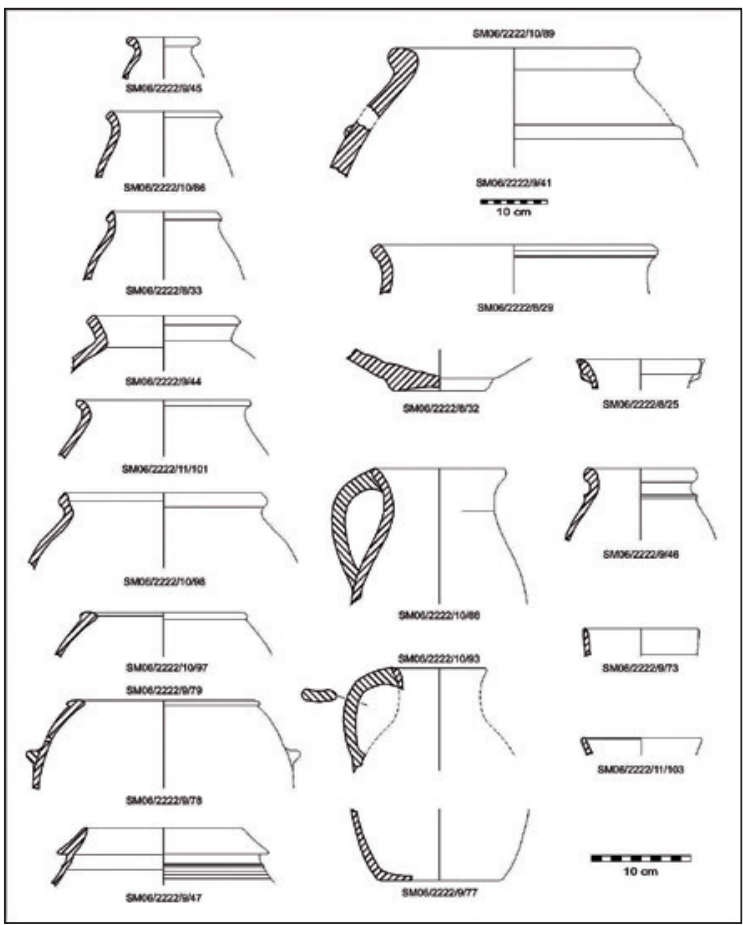

Fig. 4. Materiales cerámicos tardovisigodos de la estructura 2222/E-1.

- PEX 1282: conjunto estructural compuesto por dos tumbas en fosa simple con cubierta de tejas (UUEE 1282.5 y 1282.9), que afectan parcialmente a una fosa de planta elíptica con

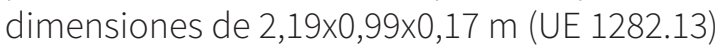
y a un silo de perfil troncocónico con una profundidad de 1,50 m (UE 1282.3). La fosa presenta un solo relleno de colmatación (UE 1282.14) que engloba material constructivo en estado fragmentario, entre el que destaca un cuadrante romano, lajas de pizarra y restos óseos humanos en posición secundaria. Asociada a los restos óseos se recuperó una hebilla de cinturón cuadrada de bronce (Fig. 7.7). La estratigrafía de la estructura siliforme está compuesta por una sucesión de rellenos de vertido que incluyen material constructivo romano reaprovechado, abundantes restos de tejas, desechos domésticos de consumo y gran cantidad de material cerámico (Fig. 3).

- PEX 2549: formado por un enterramiento en fosa simple con cubierta de tejas (UE 2549.3) superpuesto a un silo amortizado como basurero (UE 2549.8) cuya sedimentación alterna rellenos de material constructivo con otros detritus de consumo doméstico como malacofauna, restos óseos de fauna, gasterópodos y abundante material cerámico fragmentario. La estructura siliforme presenta planta circular, paredes acampanadas, fondo plano y alzado de $1,14 \mathrm{~m}$.

Entre las estructuras islámicas excavadas destacamos una serie de fosas en las que se ha detectado la presencia de restos óseos humanos en posición secundaria. Dichas acumulaciones de huesos se encuentran en desconexión anatómica y su presencia en estos contextos no responde, a juzgar por la naturaleza de los rellenos donde se encuentran estratificados, a una intencionalidad funeraria, por lo que debemos entenderla como consecuencia de la remoción o el desmantelamiento de contextos sepulcrales anteriores. Las tres estructuras documentadas (PEX 1239, 1257 y 1870) se localizan en el espacio que ocupa la necrópolis de época visigoda, incluso una de ellas se superpone a uno de los enterramientos de este periodo (PEX 1257). El material cerámico recuperado en su interior indica una cronología almohade, al menos para la fosa 1257.

Hasta el momento y a la vista de las cronologías que se valoran en el estudio cerámico, se propone una secuencia cultural dividida en seis fases que describen y explican el proceso de ocupación continuado de este sector del yacimiento durante la Edad Media; son las siguientes:

1. Fase tardorromana: por ahora se encuentra mínimamente documentada a nivel estructural en una única fosa siliforme con elementos culturales esporádicos (UUEE 2566.11 y 2566.12) (Fig. 10).

2. Fase necrópolis hispano-visigoda $\left(2^{\mathrm{a}}\right.$ mitad S. VI- S. VII): comprende un conjunto de 9 sepulturas cuyo estudio ha sido publicado en otro trabajo (BATANERO, BELTRÁN y VERA, 2016); representan el primer uso cementerial de la zona.

3. Fase de transición época visigoda/periodo islámico ( $1^{\mathrm{a}}$ mitad $\mathrm{s}$. VIII): en este artículo 
abordamos el estudio de una estructura de tipo silo, integrada en el PEX 2222, cuya particularidad consiste en albergar una inhumación de carácter extracementerial y sin ritual funerario normalizado, una práctica que se constata ampliamente en yacimientos tardo-visigodos de la Meseta central y Cataluña. Están en estudio otros silos cuyos materiales apuntan a este momento.

4. Fase necrópolis islámica I emiral (ss. VIIIIIX).

5. Fase islámica califal-taifa (ss. X-XI): estratigráficamente relacionado con ambas fases de la necrópolis islámica, evoluciona en este sector un campo de silos y otras estructuras subterráneas, cuya amortización ofrece principalmente elementos culturales del siglo X, amén de otros aportes más recientes, que evidencian un amplio episodio de uso agrícola.

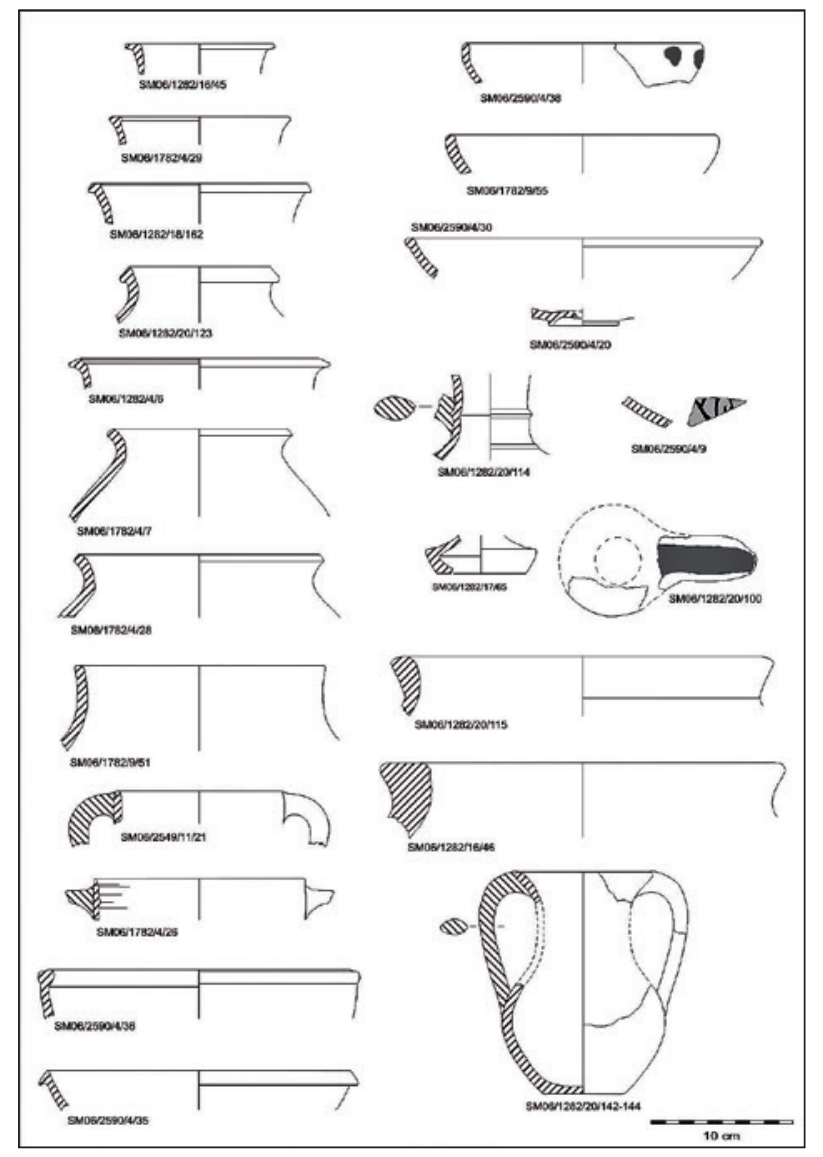

Fig. 5. Materiales cerámicos procedentes de los silos y estructuras califales.
6. Fase necrópolis islámica II (s. XII). Paralelamente a los restos funerarios, se tiene identificada al menos una fosa (PEX 1257) con material cerámico claramente almohade.

\subsection{Análisis de la cultura material: indicadores cronológicos}

\subsubsection{El contexto 2222 y los registros materiales de transición al mundo islámico}

El contexto arqueológico identificado como PEX 2222 está compuesto por dos subestructuras siliformes con relación de corte, cuyos registros materiales no ofrecen diferencias sustanciales. Sobre el suelo de la estructura más antigua (Est. 2222/E-1) se depositó, de manera anómala y sin signos evidentes de tratamiento funerario, un individuo adulto masculino sepultado posteriormente con niveles de escombros que contenían abundante material cerámico (Fig. 8). El conjunto mueble recuperado en estas capas de acarreo se nos manifiesta principalmente como un conjunto homogéneo de cerámicas comunes, correspondiente a una producción doméstica poco estandarizada, cuyo repertorio formal aparece muy reducido, con predominio funcional de las formas cerradas destinadas a la cocción (ollas) y al servicio del agua (jarros/as), así como en menor proporción al almacenamiento (orza, tinaja). A nivel tecnológico, estos grupos cerámicos se caracterizan por estar elaborados mayoritariamente a mano/ torneta, con cocciones diversas, siendo más frecuente la reducción; las pastas se presentan poco depuradas y portan abundante desgrasante mineral de tamaño medio-grueso. Normalmente son recipientes con acabados lisos sin decoración, aunque ocasionalmente se documentan aplicaciones plásticas, como cordones lisos o con impresiones digitadas; un único fragmento de disco de cocción presenta decoración estampillada con motivo de rombos (Fig. 7.2). Frente a este conjunto cerámico existen, aunque minoritarios, otros formatos 


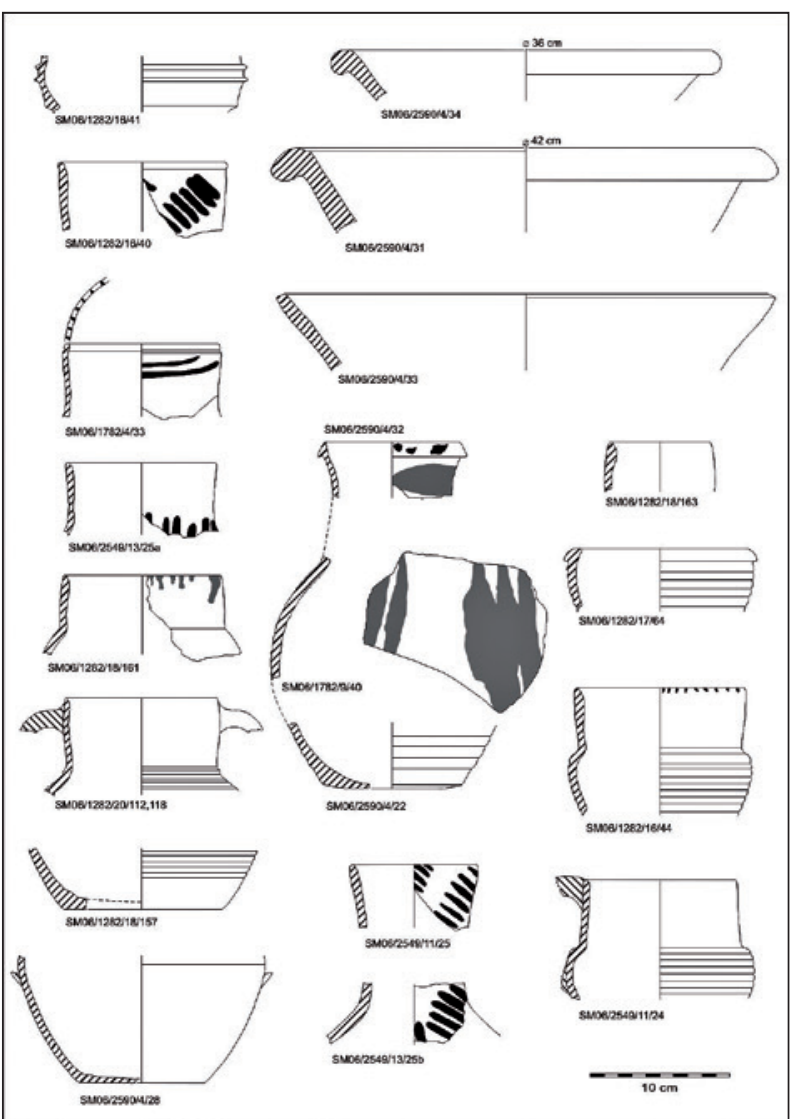

Fig. 6. Materiales cerámicos procedentes de los silos y estructuras califales.

que representan la continuidad tecnológica con el mundo tardorromano, así como también aquellos que preludian la incorporación al ámbito cultural islámico.

Los ejemplares de cocina adscritos al formato olla se inscriben mayoritariamente en el tipo de ollas de perfil en "S", de cuerpos esféricos o piriformes, con bordes simples de sección redondeada, triangular o de labio plano, las cuales encuentran claros precedentes en las tipologías tardorromanas (Fig. 4: 33, 44, $45,86,98,101$ ). Su presencia en los conjuntos cerámicos de época visigoda es bastante frecuente, hallándose paralelos exactos en yacimientos de Madrid, incluidos dentro de las formas del grupo TL1 (a mano con rotación auxiliar) (VIGIL-ESCALERA, 2003: f. 2), Mérida (ALBA Y FEIJOO, 2003: f. 8), el Levante y el Sureste peninsular (GUTIÉRREZ, 1986: f. 4; 1993: f. 3), Córdoba (FUERTES e HIDALGO, 2003: fs. 8,
9) y Sevilla (MAESTRE, 2012: f. 8). Su cronología en estos enclaves abarca los siglos VI a VIII.

Un segundo modelo de olla (Fig. 4: 78$79,97)$ corresponde a un recipiente de cuerpo globular y borde entrante, rematado por un espesamiento exterior ornamentado mediante amplias huellas digitadas. Presenta como elemento de aprehensión unos apliques plásticos semilunares con impresiones digitales, dispuestos horizontalmente en el tercio superior de la pieza. Esta forma parece corresponderse con el tipo CATHMA 7, datada en los siglos V-VI, cuyo origen ha sido situado en las islas del Mediterráneo central (C.A.T.H.M.A., 1991: p. 38). En Cartago, la cronología de este tipo, correspondiente a la forma HMW 32 de Fulford, se ha establecido en la primera mitad del siglo VI (FULFORD y PEACOCK, 1984: p. 166). Se han identificado ejemplares similares en Tarragona (MACIAS, 2003: f. 5), Alicante (REYNOLDS, 1985: f. 4; POVEDA y PEIDRO, 2007: f. 14), Mallorca (CAU, 2007: f. 6) y Sevilla (MAESTRE et alii, 2010: f. 6; MAESTRE, 2012: f. 9), todos ellos en contextos del s. VI y relacionados con un repertorio de cocina cuyo origen se encontraría en el Mediterráneo central. En el caso de las piezas de La Orden-Seminario, las pastas rojizas y los cordones digitados nos indican una mayor conexión con las piezas hispalenses, que se consideran producciones locales (MAESTRE, 2012: p. 503).

La vajilla destinada al tratamiento de líquidos aparece representada por un tipo de jarro de cuerpo ovoide (Fig. 4: 88, 93), caracterizado por presentar perfil en " $\mathrm{S}$ ", boca ancha con borde simple redondeado y un asa desde el labio a la zona más saliente del cuerpo, cuyos paralelos más exactos se encuentran con frecuencia en el mundo hispano-visigodo. Formatos similares se localizan en la región de Madrid (formas incluidas en el grupo TL2, siglo VII-1 ${ }^{a}$ mitad siglo VIII) (VIGIL-ESCALERA, 2003: f. 3), en conjuntos cerámicos de los siglos VI-VIII emeritenses (ALBA y FEIJOO, 2003: f. 9), y en asentamientos de la cuenca del Duero (Mata del Pa- 


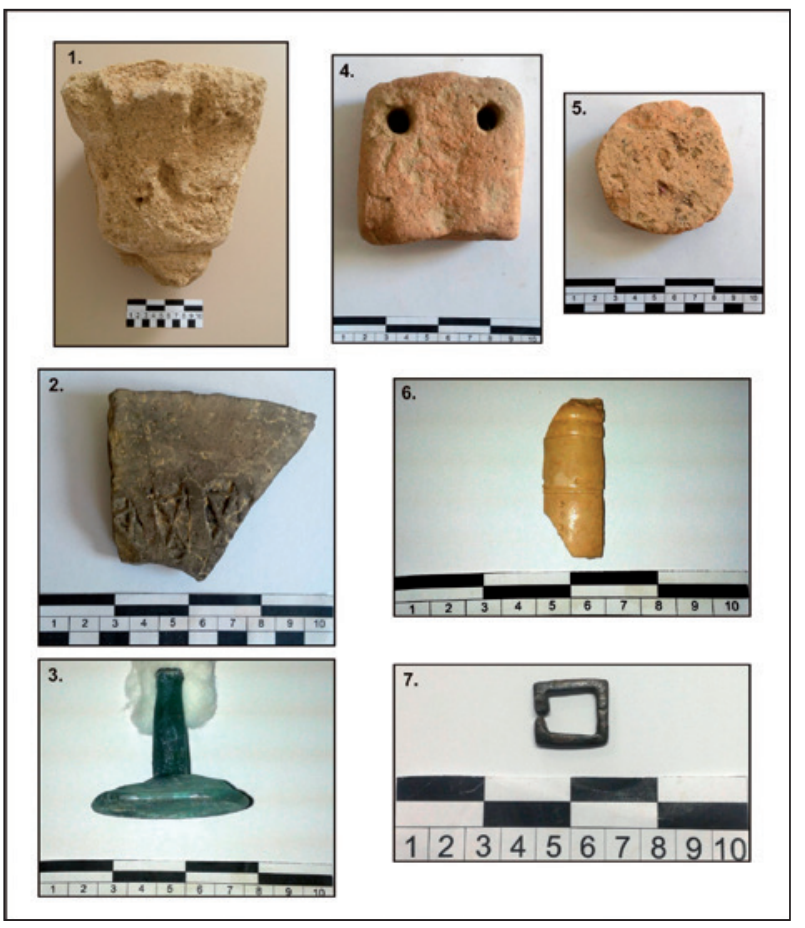

Fig. 7. Selección de materiales arqueológicos singulares.

lomar, Segovia), con fecha de finales del siglo VII a mediados del VIII (TEJERIZO, 2016: p. 244, f. 8.8).

Un segundo tipo de jarro se corresponde con un recipiente de menores dimensiones, cuyo borde, engrosado y de sección redondeada, presenta un pico vertedor poco desarrollado. El cuello, muy corto y cilíndrico, está separado del cuerpo ovoide por una moldura. El fragmento recuperado no permite conocer si disponía de asa (Fig. 4: 46).

Respecto a los fondos que pueden relacionarse con este repertorio formal, tenemos que decir que todos presentan base plana y son de configuración simple, sin que exista ruptura con el cuerpo del vaso.

Al igual que ocurre en otros registros peninsulares (ALBA y FEIJOO, 2003: p. 489), llama la atención la limitada proyección de los modelos formales englobables en la vajilla de mesa, habiéndose atestiguado solamente un cuenco de cuerpo semiesférico con borde simple re- dondeado, elaborado a torno rápido (Fig. 4: 103).

Entre los recipientes de almacenaje destaca un contenedor de grandes dimensiones y gruesas paredes rojizas con abundante desgrasante mineral de gran tamaño, visible en superficie, con decoración a base de cordones lisos horizontales, que tiene su precedente más inmediato en el dolium romano. La parte superior del cuerpo es globular y termina directamente en una boca ancha indicada por un vasto borde engrosado al exterior de sección redondeada (Fig. 4: 41, 89). En el conjunto cerámico recuperado se documenta la presencia de una rudimentaria asa de "aleta" que pudo pertenecer, a juzgar por la pasta y las intrusiones que presenta, a este tipo de tinaja. Formalmente, este tipo de contenedor guarda relación con los modelos de dolium documentados en el área catalana durante el periodo visigodo final (mediados del siglo VII y VIII) (ROIG, 2011: p. 141), atestiguándose perduraciones en yacimientos de cronología islámica (segunda mitad del siglo IX y X) como Marroquíes Bajos (PÉREZ, 2003: Im. 70), Cercadilla (FUERTES y GONZÁLEZ, 1996: f. 94) y Rábita de las Dunas de Guardamar en Alicante (AZUAR, 1989: p. 116). Dentro de este mismo grupo funcional, hacemos mención también de un fondo de pie anular correspondiente a un contenedor de tipo dolium (Fig. 4: 32) y de un borde vuelto perteneciente a una orza de boca ancha (Fig. 4: 29), ambos envases realizados a torno rápido y en ambiente oxidante, el segundo de los cuales encuentra paralelos significativos en contextos tardo-visigodos o emirales de Conimbriga (Coimbra, Portugal) (TENTE y DE MAN, 2016: p. 61, f. 2.10).

En cuanto al material destinado al transporte, únicamente se ha recuperado un borde de ánfora que conserva tan solo el arranque de una de las asas (Fig. 4: 25). Su morfología (exvasado y de sección subtriangular, asas de poco espesor y sección elíptica, insertadas en la parte superior del borde y cuello presumiblemente corto y estrecho) y sus dimensiones 


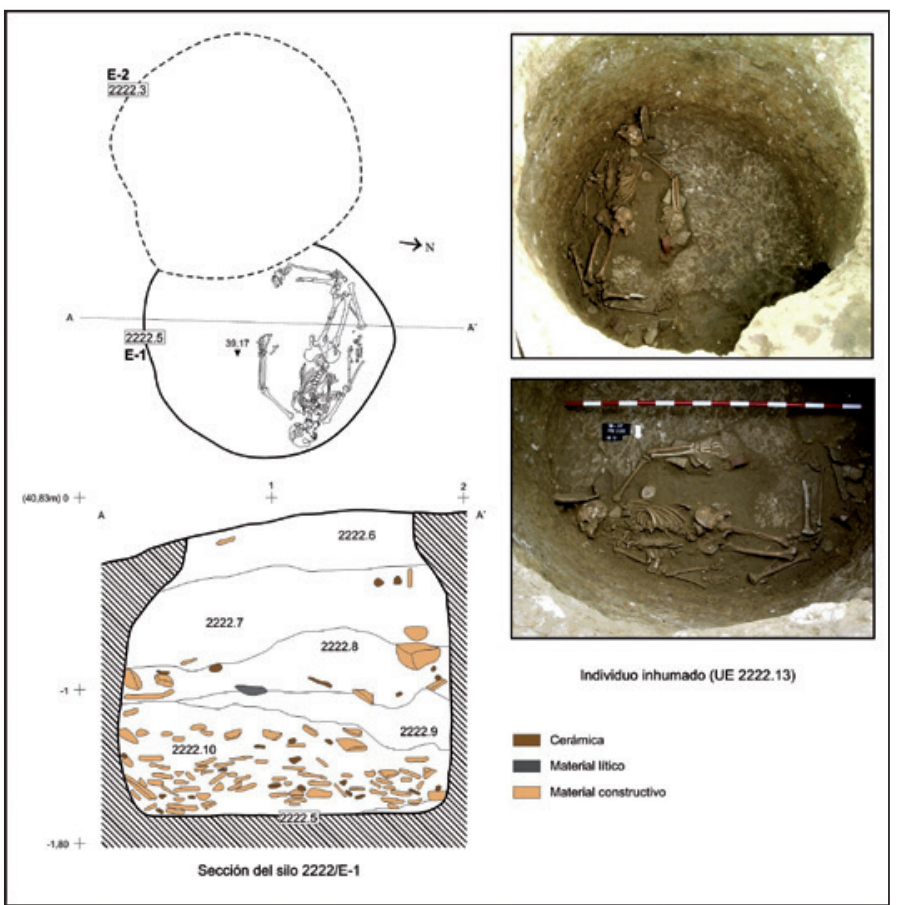

Fig. 8. Inhumación en silo (PEX 2222). paredes acanaladas y otras lisas, sin decoración, de color beige uniforme, correspondientes a tipologías inéditas en los contextos visigodos. Los materiales constatados permiten indicar la presencia de jarras/cántaros de cuerpos acanalados y de las características jarritas de cuello cilíndrico y borde simple redondeado (Fig. 4: 73), que están ya presentes en algunos registros paleoandalusíes del siglo VIII. Paralelos tempranos para este prototipo de jarritas los encontramos en Cercadilla (FUERTES y GONZÁLEZ, 1996: f. 84: 4471) y en yacimientos rurales de Madrid, donde la incorporación de producciones propias del mundo islámico, que conviven durante un amplio periodo con las producciones visigodas, se fecha a partir del último tercio del siglo VIII (VIGIL-ESCALERA, 2003: p. 385, f. 6). (boca de 11,5 cm de diámetro) encajan con la descripción de las ánforas salazoneras bajoimperiales del tipo Keay XXII/Almagro 50 y XXIII/ Almagro 51C, de procedencia lusitana, bien representadas en los centros productores del Sado-Tajo y del Algarve con cronologías centradas en los siglos III-V (MAYET y TAVARES, 2016; BERNARDES y VIEGAS, 2016). Otros registros del arco suratlántico peninsular permiten alargar el periodo de producción de estas ánforas, al menos, hasta la primera mitad del siglo VI. Dentro de este marco cronológico amplio se mencionan ejemplares en Sevilla (MAESTRE et alii, 2010: f. 3), en Lagos (RAMOS et alii, 2007: p. $88, f .3)$ y en las cetariae del litoral onubense. En estos últimos centros aparecen asociados a la producción de nuevos envases anfóricos durante los siglos V y VI (O ' KELLY, 2012).

Como elementos novedosos atestiguados en el conjunto material del contexto $2222 \mathrm{ci}$ tamos una serie de fragmentos cerámicos que responden a una tecnología más avanzada, caracterizada por el uso sistemático del torno rápido, las cocciones oxidantes homogéneas y las pastas decantadas y compactas. Se trata de
Resulta de especial interés por su excepcionalidad y significación cronológica, la presencia en el conjunto material que analizamos de vajilla de vidrio destinada al servicio de mesa (Fig. 7.3). El elemento recuperado pertenece a un tipo de copa provisto de pie alto con vástago liso, macizo y rectilíneo, aunque con un estrechamiento en la zona de unión con el cuerpo del vaso, cuyo pie es anular y de base rehundida. De tonalidad verdosa, el fragmento muestra un acabado poco cuidado, con ciertas deformaciones en el pie y multitud de burbujas de aire que, quizás, se deban a una fabricación defectuosa. Tipológicamente, este modelo de copa se incluye en el Grupo 3, serie 3.3 (predominantemente vidrios de color azulado) del estudio de Foy sobre el material vítreo procedente de los talleres de producción tunecinos, que fecha a finales del siglo VII y principios del VIII, cuya distribución se extiende especialmente por el Mediterráneo central y occidental (FOY et alii, 2003: pp. 65-68, f. 21). Constituye una forma representativa de la fase tardía hispano-visigoda, cuyo uso se generaliza durante los siglos VII-VIII, estando perfectamente caracterizada en asentamientos rurales 


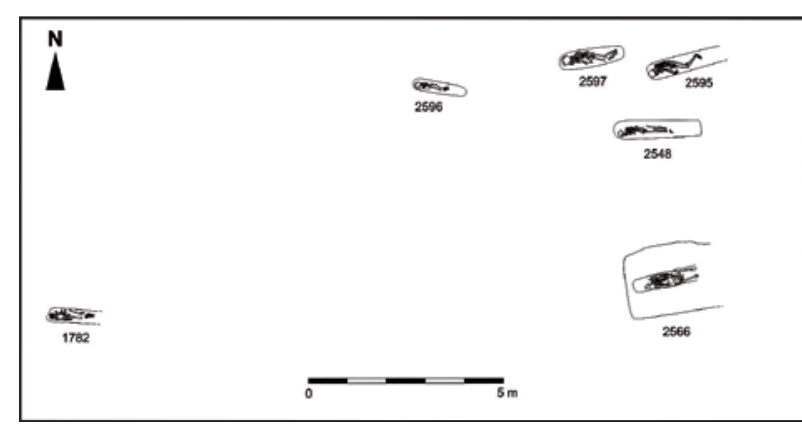

Fig. 9. Distribución de las tumbas de la necrópolis islámical.

del área catalana (ROIG, 2011: p. 142, f. 9), así como también en la ciudad de Recópolis (Zorita de los Canes, Guadalajara), donde estas copas (incluidas en el tipo Isings 111) están fabricadas mayoritariamente en material verdoso, un rasgo que se hace más patente en las producciones islámicas del mismo yacimiento durante los siglos VIII y IX (GÓMEZ DE LA TORRE-VERDEJO, 2011: pp. 265 y 271).

Para datar el conjunto analizado habría que tener en cuenta, en primer lugar, que la presencia de las producciones comunes toscas es más notoria entre mediados del siglo VII y el VIII en contextos rurales interiores y en determinados ámbitos urbanos (Mérida), coexistiendo, no obstante, con modelos torneados de cocción oxidante (ALBA y GUTIÉRREZ, 2008: p: 586). A este momento tardío en la evolución de los registros cerámicos visigodos apunta igualmente la presencia del pie de copa de vidrio documentado. La convivencia de este material con los elementos torneados, que señalan ya una etapa de presencia islámica, sugiere una cronología de la primera mitad del siglo VIII para el contexto de colmatación que representan los niveles de escombros que obliteran ambos silos.

\subsubsection{Los registros materiales de las estructuras califales}

Los elementos materiales estudiados en este apartado proceden de los silos y rebajes que se interponen estratigráficamente entre los dos grupos de tumbas que forman la ne- crópolis, los cuales se encuentran integrados en los PEX 1282, 1782, 2549 y 2590. Los materiales cerámicos recuperados en estos contextos ofrecen características muy similares, por lo que se afronta su estudio conjuntamente.

Como rasgos generales del lote cerámico exhumado distinguimos la alta proporción de formas cerradas, comunes o con decoración pintada, y la escasa representación de las series vidriadas, que suponen ya, junto con la ausencia de producciones esmaltadas en verde-manganeso y las decoradas a cuerda seca, elementos claramente diferenciadores bien a nivel cronológico, bien como indicadores para la definición del contexto social subyacente.

La vajilla culinaria destinada a la cocción está abundantemente representada por un tipo de marmita de larga tradición que, como hemos visto en el estudio del contexto 2222, muestra cuerpos globulares y bordes vueltos de diversa configuración. Tanto en su versión de labio redondeado o plano, como de forma triangular (con o sin escotadura interior para tapadera) (Fig. 5: 6, 7, 28, 51, 123), se documentan ampliamente en la estratigrafía del criptopórtico de Cercadilla durante los siglos IX y X (FUERTES y GONZÁLEZ, 1996). Está presente asimismo en contextos del siglo XI en Niebla (BELTRÁN, 2005: f. 4). Otro tipo de marmita con bordes moldurados hacia el exterior (Fig. 5: 29, $45,162)$ se asemeja a modelos califales cordobeses (FUERTES y GONZÁLEZ, 1996: f. 90), también documentados en Bayyana (Pechina, Almería) (CASTILLO y MARTíNEZ, 1993: Im. I) y Niebla (BELTRÁN, 2005: f. 4), con cronologías del siglo IX y XI, respectivamente. Un tercer modelo característico ofrece cuellos cilíndricos poco desarrollados y bordes verticales o ligeramente vueltos, de donde parten dos asas (Fig. 5: 21, 26). Esta forma se identifica con el tipo de marmita más frecuente y característico en los conjuntos cerámicos califales de Madinat al-Zahra (VALLEJO y ESCUDERO, 1999: f. 13), estando presente también en los contextos de los siglos IX-X del yacimiento de "El Castillón" (Montefrío, Granada) (MOTOS, 1993: f. 4). 
Entre las cazuelas señalamos dos ejemplares bizcochados: uno con cuerpo hemisférico y reborde triangular (Fig. 5: 35) y el otro con cuerpo de paredes rectas y verticales, al menos en su tramo superior, que remata en un borde engrosado en ambas caras (Fig. 5: 36). Esta última pieza encuentra paralelos cercanos entre las cerámicas iliplenses de época taifa (BELTRÁN, 2005: f. 4).

La vajilla de mesa está representada por algunos ejemplares de ataifor, distinguiéndose entre aquellos que muestran superficies bizcochadas o con decoración pintada de los que presentan vidriados en verde o melado. Entre los primeros señalamos dos ejemplares hemisféricos de labio simple redondeado, uno de los cuales exhibe goterones de pintura roja bajo el exterior del borde (Fig. 5: 38, 55). Se trata de un modelo que M. Retuerce incluye en la forma A.01 de su estudio sobre los materiales islámicos de la Meseta, que sitúa en una fase emiral-califal, con una distribución centrada principalmente en torno a la zona del Bajo Guadiana y el Algarve portugués (RETUERCE, 1998: pp. 81-83, fs. 1-5). La serie vidriada está ejemplificada en un tipo de ataifor de perfil hemisférico, borde engrosado al exterior y solero en anillo (Fig. 5: 20, 30), del que se ha documentado algún fragmento decorado en manganeso bajo cubierta melada, probablemente con motivo de palmeta (Fig. 5: 9). Es un formato muy común en al-Andalus, extendiéndose por casi toda su geografía. Se encuadra dentro del tipo A.08.B de la clasificación de M. Retuerce, quien hace hincapié sobre su cronología situada a caballo entre el siglo X y el XI (RETUERCE, 1998: pp. 90-94). Ejemplares tempranos se documentan en los primeros niveles islámicos de Málaga, fechados a finales del siglo IX (ACIÉN et alii, 2003: fs. 4-5), mientras que en Niebla están presentes en contextos del siglo XI (BELTRÁN, 2005: f. 5).

A la forma redoma corresponde un fragmento de cuello cilíndrico con moldura de donde parte un asa (Fig. 5: 114), pudiendo pertenecer a recipientes del tipo B.04 o B.05 de Retuerce, cuya cronología se encuadra en los siglos X-XI (RETUERCE, 1998: fs. 95-99).
Entre las jarritas más frecuentes se encuentran las que presentan cuello cilíndrico y cuerpo globular o piriforme, en todo caso de hombros redondeados (Fig. 6: 25a, 33, 40, 118, 161), asociadas a fondos de base plana (Fig. 6: 157) y bordes indicados al exterior o biselados al interior. Suelen llevar decoración de pintura roja o negra en forma de goterones o trazos digitados, dispuestos en el cuello o en la parte superior del cuerpo. Se trata de una forma muy habitual en los repertorios cerámicos andalusíes desde el siglo IX hasta el XIII, careciendo de elementos evolutivos que permitan establecer precisiones cronológicas.

Características de los siglos X-XI son las jarritas de cuerpo cilíndrico moldurado con carena baja (Fig. 6: 41), muy abundantes en Niebla (OLMO, 1986a: f. 2; BELTRÁN, 2005: f. 6), y de las que encontramos otros paralelos en Mesas de Asta (OLMO, 1986b: Im. IV) y Jerez de la Frontera (AGUILAR, GONZÁLEZ y BARRIONUEVO, 1998: f. 1).

También son relativamente abundantes en el conjunto analizado los jarritos de una sola asa, con cuello cilíndrico, hombros carenados y cuerpo estriado y ovoide (Fig. 6: 24, 44). Este tipo es bastante bien conocido, con abundantes paralelos en todo el territorio andalusí de los siglos X y XI (OLMO, 1986a: p. 137; RETUERCE, 1998: pp. 196-199, fs. 159-161).

Dentro de la serie jarra se constata cierta variedad formal. Los elementos recuperados señalan la existencia de ejemplares con decoración pintada a base de trazos digitados en manganeso o almagra, que suelen ocupar parte de la panza, del cuello y del borde. La reconstrucción de la figura 6 permite definir parcialmente un tipo de recipiente de cuerpo ovoide, base convexa y cuello troncocónico o cilíndrico que termina en un borde con engrosamiento exterior de sección triangular (Fig. 6: 22, 32, 40), formalmente relacionado con las jarras califales de Madinat al-Zahra (VALLEJO y ESCUDERO, 1999: f. 4), con ejemplares del siglo XII de Niebla (BENABAT y PÉREZ, 2003: $\mathrm{f}$. 3) y con las producciones de cántaros de Aeminium (Coimbra, Portugal) centradas entre los 


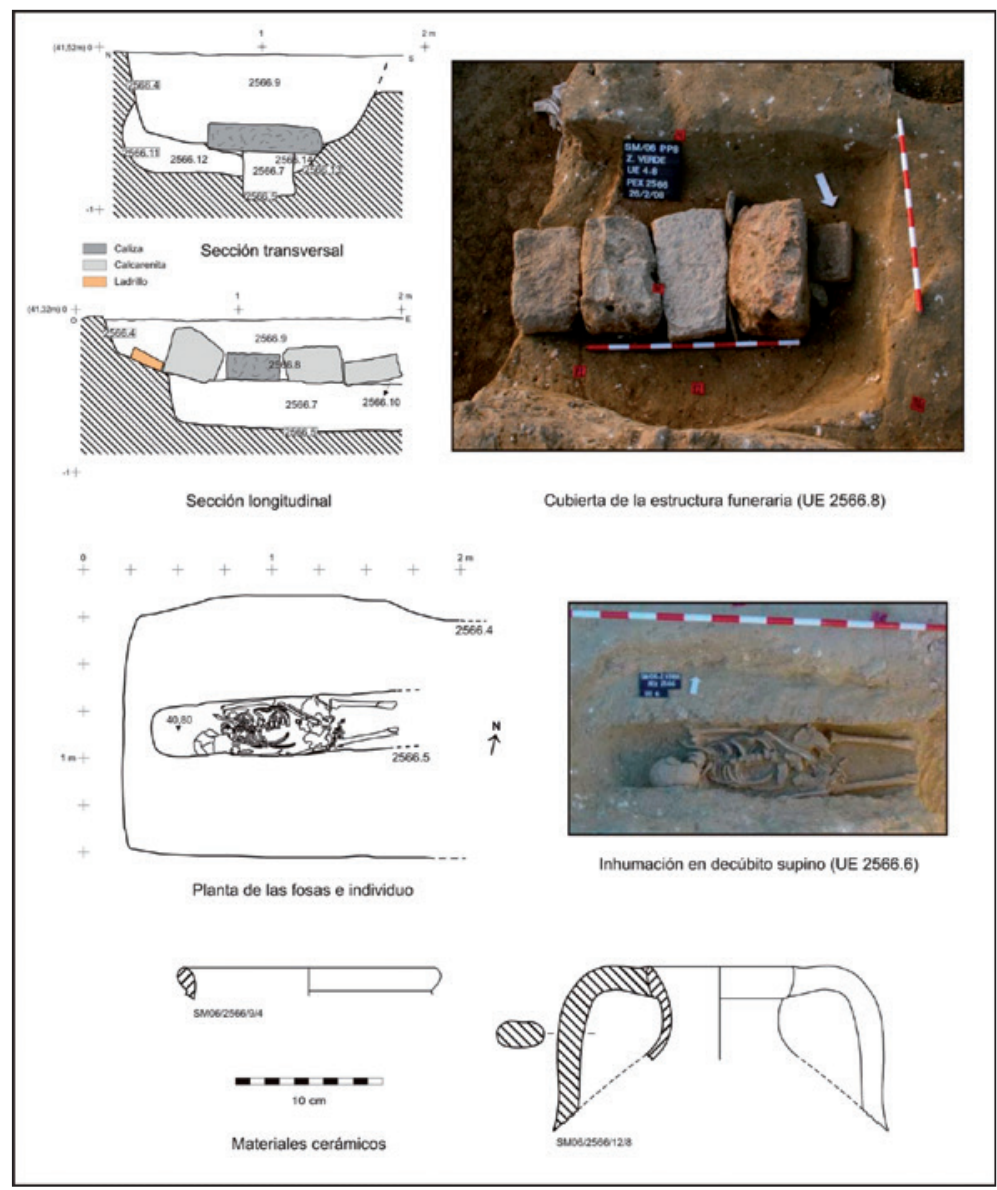

Fig. 10. Enterramiento con prefosa y fosa de inhumación central sobre silo tardorromano (PEX 2566).

siglos IX y XII (TENTE y DE MAN, 2016: f. 2.14). El fragmento de jarra con cuello convexo y borde engrosado al exterior (Fig. 6: 64) encuentra también en Niebla sus paralelos más cercanos, documentándose en esta localidad en contextos de los siglos XI y XII (BENABAT y PÉREZ, 2003: f. 3; BELTRÁN, 2005: f. 7). Otros elementos recuperados nos remiten a jarras de cuerpo ovoide, cuello cilíndrico, con tendencia al exvasamiento y borde simple de labio redondeado (Fig. 6: 25, 25b), o a recipientes de boca acampanada, cuerpo piriforme y base plana, con dos asas que se desarrollan desde el borde hasta el hombro (Fig. 5: 142-144).

Entre la vajilla de uso múltiple se encuentran alcadafes de grandes dimensiones, de cuerpos troncocónicos y espesos rebordes exteriores, normalmente con el interior bruñido
(Fig. 6: 31, 34). Un segundo modelo de menores proporciones presenta borde simple de labio plano (Fig. 6: 33), para el que encontramos analogías en ejemplares epicalifales de Niebla (BELTRÁN, 2005: f. 7).

Otros elementos cerámicos de interés son dos bordes pertenecientes a tinajas (Fig. 5: 46, 115), probablemente de forma ovoide, y diversos fragmentos de candiles, entre ellos una cazoleta bitroncocónica de base plana y reborde en el perímetro del disco, al que estarían asociadas piqueras alargadas en forma de "quilla de barco" (Fig. 5: 65, 100). En el primer caso, los fragmentos recuperados guardan relación con ejemplares emirales y califales de Bayyana (CASTILLO y MARTÍNEZ, 1993: Im. XXI) y Montefrío (MOTOS, 1993: f. 9). Los elementos descritos para los candiles se encuadran en el 
tipo IVa de época califal de la clasificación de G. Rosselló (1978: p. 51, f. 10) y en el tipo 6.2b del nivel I de la Rábita de las Dunas de Guardamar, cuya cronología se sitúa entre finales del siglo X y el primer cuarto del XI (AZUAR, 1989: p. 126). Se ajustan, asimismo, a las características propias de los ejemplares califales de CercadiIla (FUERTES, 2000: p. 228).

Entre los materiales no cerámicos, localizados en este caso en los depósitos de vertido del silo UE 1282.3, cabe señalar especialmente el hallazgo de un fragmento de hueso cilíndrico, de unos $6 \mathrm{~cm}$ de largo por 2,5 cm de ancho, cuidadosamente pulido y decorado (Fig. 7.6). Uno de los extremos del fragmento, el que creemos es el superior, se encuentra ornamentado mediante dos molduras realizadas a torno, a partir de las cuales se desarrolla escuetamente una decoración a base de círculos, algunos con punto central, distribuidos en dos grupos y separados por dos líneas incisas formando una banda transversal. Aun cuando contemos solamente con una pequeña superficie de la decoración, los elementos descritos presentan extraordinarias similitudes, por su diseño y disposición, con la ornamentación que ostentan diversas piezas califales procedentes de Córdoba, que han sido estudiadas e interpretadas como objetos lúdicos, concretamente como muñecas, por E. Ruiz Nieto (2001). Las piezas cordobesas muestran la decoración completa de este tipo de objetos, cuya singularidad reside en la representación de rasgos antropomórficos faciales y corporales. Comparando el fragmento de La Orden-Seminario con los registros cordobeses (RUIZ, 2001: Ims. I-II), podemos inferir que el trozo de hueso recuperado se corresponde con la parte media-inferior de la pieza, en la que es visible, siguiendo la interpretación de este autor, el marcado de los senos y de la botonadura de la vestimenta de la figura.

Tanto la homogeneidad material del repertorio analizado, como su propia distribución estratigráfica y estructural dentro de la secuencia cultural que se baraja para esta zona del yacimiento, nos indican en principio que nos encontramos ante un mismo contexto temporal.
La frecuencia de los tipos formales que entroncan principalmente con el mundo califal, unido a la presencia casi anecdótica de cerámicas vidriadas, aunque bien definidas crono-tipológicamente, y a la ausencia de técnicas decorativas características como el verde-manganeso y la cuerda seca, cuya producción se generaliza en momentos epicalifales (CANO, 1996: p. 51; MORENO, 1987: p. 41), permiten encuadrar el conjunto estudiado en un horizonte cronológico centrado en el siglo $X$.

\section{EL ENTERRAMIENTO EN SILO (ESTRUCTURA 2222/E-1, UE 2222.5)}

Una línea de investigación reciente en los estudios sobre el mundo funerario de época altomedieval en la Península Ibérica es la que concierne a la amortización de estructuras de almacenamiento de tipo silo como zonas o lugares específicos de enterramiento extracementerial. Hasta el momento, las mayores concentraciones de depósitos humanos en fosas de diverso tipo se han registrado en la Meseta central y Cataluña, constituyendo una práctica formalmente muy homogénea y generalizada en los asentamientos rurales de ambos ámbitos territoriales. Al igual que ocurre en los registros obtenidos en estas dos áreas, las evidencias de La Orden-Seminario reproducen una serie de pautas reiterativas y singulares cuya significación y alcance, en lo referente a su formación, naturaleza y significado social, vienen siendo objeto de interpretaciones y enfoques de diversa índole (LÓPEZ, 2010: pp. 292-296; VIGIL-ESCALERA, 2013; ROIG, 2015), al tiempo que, particularmente, suponen una extensión del fenómeno fuera de los focos que hasta la fecha aglutinan la mayoría de los casos documentados.

La inhumación anómala constatada en el PEX 2222 se encuentra ubicada en un espacio densamente ocupado por silos de fases sucesivas y está separada del grupo de sepulturas correspondiente al cementerio de época visigoda a una distancia de 15 m aproximadamente (Fig. 2). Es coetánea a otras estructuras siliformes que se localizan muy próximas entre 
sí, formando alineaciones más o menos definidas, cuyo material se encuentra aún en fase de estudio. Morfológicamente, el silo 2222/E-1 (UE 2222.5) presenta sección acampanada en su parte superior y más cercana a su boca, para luego seguir con las paredes verticales hasta el fondo, regular y plano. Tiene unas dimensiones en planta de 1,25 m de longitud en el eje este-oeste y de $1 \mathrm{~m}$ en el eje norte-sur, alcanzando una profundidad máxima de 1,60 m. En su base ofrece unas dimensiones de $1,70 \mathrm{~m}$ de longitud en el eje norte-sur y 1,50 m en el eje este-oeste. Una vez colmatada esta primera estructura, se excavó un segundo silo de sección cilíndrica (Estructura 2222/E-2, UE 2222.3), amortizado como basurero, que afectaría de manera nimia el alzado de aquélla, pero sin llegar a alterar los restos óseos del depósito humano (Fig. 8).

El cuerpo alojado en el primer silo, correspondiente a un varón de edad madura, se depositó directamente sobre su base. La posición anatómica anómala en la que encontramos al individuo parece indicar que fue depositado en el interior de la estructura de almacenamiento de forma poco convencional, es decir, sin responder a ningún ritual funerario específico, encontrándose en una posición de decúbito lateral derecho parcial, con piernas semiflexionadas hacia atrás (con cota más alta en rodillas) y brazos semiflexionados a ambos lados del tórax, pero separados de este. El cuerpo, finalmente, habría quedado dispuesto a lo largo de la pared norte de la fosa, con las extremidades inferiores amoldadas al contorno de la estructura y la cara dirigida hacia la pared con una orientación de sagital de $180^{\circ}$ Este. No se aprecian importantes actuaciones preparatorias o de acondicionamiento funerario intencionadas, salvo que podamos considerar como tales el emplazamiento bajo el antebrazo y la mano izquierdos de sendos ladrillos de apoyo, o la colocación de dos trozos de tejas sobre la parte posterior del cráneo que, dispuestas verticalmente, tuvieran la función de apuntalar la cabeza del individuo. En cualquier caso, la disposición del cuerpo se corresponde con posturas que han sido interpretadas como forzadas e irregulares, las cuales son represen- tativas del arrojamiento indiscriminado de los cadáveres al interior de las estructuras, sin que exista manipulación ulterior de los mismos (ROIG 2015: fs. 18.20, 18.21), si bien, en nuestro caso, es posible que el cuerpo recibiera un somero tratamiento mediante la implementación de los elementos mencionados.

La desarticulación de los huesos a nivel de cráneo, cervicales y lumbares, producida en el proceso de esqueletización, así como el notable desplazamiento de las piernas y del antebrazo derecho, quizás en una fase posterior de frecuentación y rellenado del silo, indica que el cadáver se descompuso al vacío o, en todo caso, ligeramente cubierto con tierras, lo que explicaría la fijación postural de ciertas partes del cuerpo, como el brazo izquierdo y el tórax. En este sentido y aunque no existen evidencias al respecto, la fosa pudo haber sido taponada mediante algún tipo de cerramiento en su boca hasta su definitiva amortización como contenedor de escombros y basuras.

El cuerpo depositado en el silo pertenece a un individuo masculino adulto maduro (43-53 años), de 1,59 $\pm 6,96 \mathrm{~m}$ de estatura. Los rasgos funcionales detectados en el esqueleto indican lateralidad diestra y diversas huellas de estrés funcional en las extremidades superiores (pectoral mayor, tríceps braquial, serrato anterior, bíceps braquial, flexor de los dedos y glúteo mayor). Se ha registrado patología degenerativa osteoarticular leve en la zona lumbar y extremidades inferiores, así como pérdidas dentales en vida. Presenta además patología dental (caries y cálculo) y dos impactos traumáticos, uno antiguo en costilla y otro en fase de recuperación en un hueso de la mano derecha.

Según la información estratigráfica obteni$\mathrm{da}$, los primeros escombros vertidos en el interior del silo empezaron a producirse cuando el cuerpo estaba en completo estado de esqueletización, por lo que la estructura debió permanecer vacía durante un tiempo una vez depositado el cadáver. Estos rellenos consisten en tongadas horizontales de fragmentos de tejas y tierras cuya organización y disposición evi- 
dencia una deposición controlada e intencionada, quizás relacionada con el cerramiento deliberado y definitivo del depósito humano ya osificado. Sobre este nivel masivo se superponen otros rellenos de acarreo formados por escombros y desechos domésticos que evolucionan hasta la total colmatación del silo. Teniendo en cuenta los rasgos y características del repertorio mueble recuperado en estos depósitos, la amortización de la estructura, como hemos visto anteriormente, se situaría en la primera mitad del siglo VIII.

\section{LA NECRÓPOLIS HISPANO- MUSULMANA}

\subsection{Los contextos funerarios: aspectos topográficos y constructivos}

\subsubsection{La necrópolis de la fase I (periodo emiral, siglos VIII-IX)}

El conjunto de tumbas correspondiente a la fase emiral ocupa una superficie aproximada de $122 \mathrm{~m}^{2}$ y está formado por un total de seis estructuras más o menos agrupadas en la parte norte de la denominada "Zona Verde" del yacimiento, localizándose justo en medio de los dos sectores en que se divide el cementerio de la fase II y a unos 25 metros al norte de la necrópolis hispano-visigoda (Fig. 2).

Respecto a la distribución de las tumbas, encontramos, en el límite de separación entre la "Zona Verde" y el denominado "Vial 2B", un conjunto de cinco estructuras que se disponen de manera no homogénea en un espacio que forma una especie de $L$ invertida, en el que el enterramiento de mayores proporciones y diferente tipología ocupa una posición segregada del resto. Una sexta estructura se encuentra aislada en el límite entre los sectores "Zona Verde" y "Talud" y separada del núcleo principal unos 12 m en dirección suroeste (Fig. 9).

Todas las tumbas contienen inhumaciones individuales y consisten en simples fosas excavadas en el sustrato geológico, sin ningún tipo de enlucido o elemento constructivo de reves- timiento. Tampoco se han reconocido evidencias que supongan señalización alguna de las mismas. En cuanto a sus dimensiones, existe una clara diferencia entre las que alojan inhumaciones de individuos adultos y las infantiles. Las primeras presentan longitudes en torno a los $2 \mathrm{~m}$, con anchuras que varían entre 0,38 y $0,45 \mathrm{~m}$, mientras que las infantiles no superan el metro y medio de longitud, mostrando una anchura de 0,25-0,36 m.

Morfológicamente se han podido distinguir dos tipos de sepulturas:

1. Tumbas de fosa simple de planta rectangular y paredes verticales, con ambos extremos curvos, o solo con la cabecera redondeada, que aparecen cubiertas por una hilada de tejas dispuestas transversalmente a la fosa, con su cara cóncava hacia abajo, algunas de las cuales presentan decoración impresa digital con motivos lineales ondulados (tumbas 1782, 2548 y 2595) (Figs. 12 y 14). En los enterramientos 2596 y 2597 no se han registrado los restos de las cubiertas, aunque tanto las condiciones de descomposición del inhumado, de tipo aerobio, como la presencia de fragmentos de tejas en los rellenos que colmatan las fosas, indican que originalmente las portarían. Se da la circunstancia de que el último de los enterramientos se encuentra afectado, como hemos mencionado anteriormente, por una estructura posterior (PEX 2590).

2. Tumba con prefosa rectangular y fosa de inhumación central, con cabecera redondeada. Atiende a esta tipología la estructura 2566, en cuyo interior se depositó un individuo en posición decúbito supino extendido. La cubierta de la fosa de inhumación está constituida por cuatro sillares de calcarenita y un ladrillo de módulo romano en la cabecera, colocados transversalmente a su eje, que nos recuerda el sistema de cubrición de los enterramientos de época visigoda documentados en este mismo yacimiento (BATANERO, BELTRÁN y VERA, 2016). La prefosa ofrece una anchura de $1,47 \mathrm{~m}$ y una longitud conservada de 1,76 m. Sus 
Tabla 1. Enterramientos de la necrópolis islámica fase I

\begin{tabular}{|c|c|c|c|c|c|c|c|c|c|c|c|c|}
\hline ENT. & POSICIÓN CADAVER & ORIENT. & SAGITAL & CARA & FOSA & DIMENSIONES (m) & CUBIERTA & $\begin{array}{c}\text { SEX } \\
0\end{array}$ & EDAD & $\begin{array}{l}\text { ESTAT. } \\
\text { (m) }\end{array}$ & SUDARIO & MEDIO \\
\hline 1782 & $\begin{array}{l}\text { DLD Extremidades } \\
\text { extendidas }\end{array}$ & $E-O$ & 27590 & - & $\begin{array}{l}\text { Rect. Cabecera } \\
\text { curva }\end{array}$ & $\begin{array}{c}(+1,33) \times 0,40 x \\
0,16\end{array}$ & Tejas & A & $\begin{array}{l}\text { Adulto joven } \\
\text { ( } 30-40 \text { a.) }\end{array}$ & $\begin{array}{c}1,67 \pm \\
6,96\end{array}$ & No & Aerobio \\
\hline 2548 & $\begin{array}{l}\text { DLD Brazo izqdo. semiflex. } \\
\text { Brazo dcho. y piernas ext. }\end{array}$ & $E-0$ & 26590 & $S$ & $\begin{array}{l}\text { Rect. Cabecera } \\
\text { curva }\end{array}$ & $\begin{array}{c}2,20 \times 0,42 \mathrm{x} \\
0,46\end{array}$ & Tejas & $F ?$ & Adulto & $\begin{array}{l}1,63 \pm \\
6,96\end{array}$ & No & Aerobio \\
\hline 2566 & $\begin{array}{l}\text { DS Extremidades } \\
\text { extendidas }\end{array}$ & $E-0$ & 26090 & E & $\begin{array}{l}\text { Rect. Cabecera } \\
\text { curva }\end{array}$ & $(+1,50) \times 0,38$ & $\begin{array}{l}\text { Sillares } \\
\text { ladrillo }\end{array}$ & M & Adulto joven & $\begin{array}{c}1,67 \pm \\
6,96\end{array}$ & $\mathrm{Si}$ & Aerobio \\
\hline 2595 & $\begin{array}{l}\text { DLD Extremidades } \\
\text { semiflexionadas }\end{array}$ & $E-0$ & $255^{\circ} 0$ & $S$ & $\begin{array}{l}\text { Rect. Cabecera } \\
\text { curva }\end{array}$ & $\begin{array}{c}1,94 \times 0,45 x \\
0,28\end{array}$ & Tejas & M & $\begin{array}{l}\text { Adulto joven } \\
\text { (28-32 a.) }\end{array}$ & $\begin{array}{l}1,64 \pm \\
6,96\end{array}$ & No & Aerobio \\
\hline 2596 & $\begin{array}{l}\text { DLD Extremidades } \\
\text { semiflexionadas }\end{array}$ & $E-0$ & 29090 & $\mathrm{~s}$ & $\begin{array}{l}\text { Rect. Extremos } \\
\text { red. }\end{array}$ & $\begin{array}{c}1,32 \times 0,25 x \\
0,17\end{array}$ & - & A & $\begin{array}{l}\text { Infantil I } \\
\text { (3-4 a.) }\end{array}$ & - & No & Aerobio? \\
\hline 2597 & $\begin{array}{l}\text { DLD Extremidades } \\
\text { semiflexionadas }\end{array}$ & $E-O$ & 24590 & S-SE & $\begin{array}{l}\text { Rect. Extremos } \\
\text { red. }\end{array}$ & $\begin{array}{c}1,10 \times 0,36 \mathrm{x} \\
0,18\end{array}$ & - & A & $\begin{array}{l}\text { Infantil I } \\
\text { (5-6 a.) }\end{array}$ & - & Si & Aerobio \\
\hline
\end{tabular}

peculiares características constructivas, así como por el rito funerario, nos hacen pensar que se trata de un enterramiento cristiano, supuesto que abordaremos en otro apartado (Fig. 10).

El módulo de la teja utilizado en las cubriciones, algo mayor que el constatado en las sepulturas de la segunda fase, presenta unas dimensiones aproximadas de $50 \mathrm{~cm}$ de longitud, 27-22 cm de anchura en su extremo más ancho y 18-14 cm en su extremo más estrecho.

De manera general, podemos considerar que las tumbas muestran una tendencia a orientarse en sentido este-oeste, disponiendo la cabecera a Poniente. Las orientaciones documentadas ofrecen, no obstante, ligeras variaciones que oscilan entre los $245^{\circ}$ respecto al Norte, de la tumba 2597, y los $290^{\circ}$ de la 2596, que supondría el valor más alejado respecto a la posición canónica de la qibla.

\subsubsection{La necrópolis de la fase II (siglo XII)}

La segunda fase de enterramientos islámicos documentada en La Orden-Seminario abar- ca un total de 26 estructuras diseminadas por los sectores "Vial 2B", "Zona Verde" y "Talud". Se organizan en torno a tres espacios funerarios segregados, los cuales se encuentran emplazados a ambos lados del conjunto de tumbas que corresponden a la fase anterior, siguiendo una línea con esta en sentido noroeste-sureste, sin que en ningún momento se produzcan superposiciones entre sepulturas (Fig. 2).

El conjunto más occidental y numeroso está formado por 11 sepulcros cuya disposición ofrece cierta regularidad, observándose claramente dos alineaciones de sepulturas entre las que discurren unos espacios mínimos para facilitar el paso. La segunda agrupación de enterramientos está compuesta por 8 estructuras, a una distancia de unos $18 \mathrm{~m}$ al Este del primer grupo, cuya distribución permite también observar cierta disposición organizada. El conjunto más oriental, separado unos 8 m del anterior, se compone de 6 fosas con una distribución menos uniforme. En las alineaciones más regulares la separación entre las tumbas suele ser de algo menos de $1 \mathrm{~m}$. Un último sepulcro aislado se encuentra ubicado en medio de la primera y segunda áreas de enterramiento (Fig. 11).

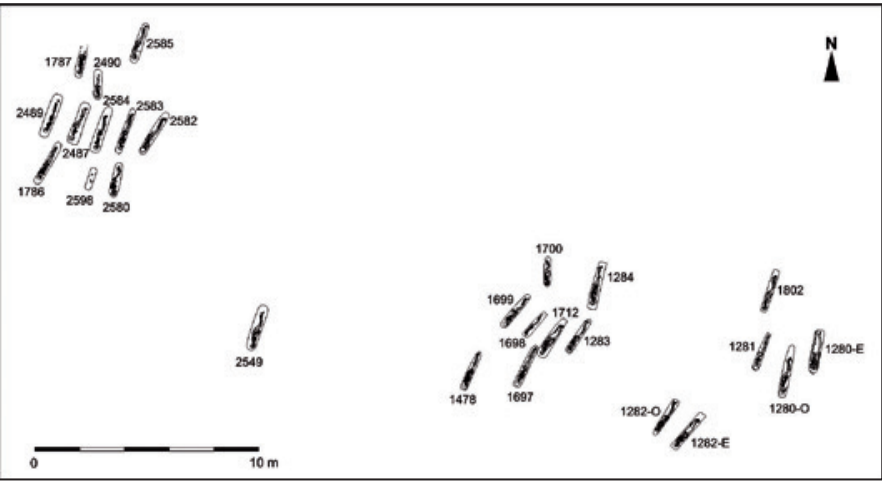

Fig. 11. Distribución de las tumbas de la necrópolis islámica II.
Al igual que en la fase I, las estructuras funerarias son simples fosas de morfología rectangular (Tipo I) excavadas en el sustrato geológico, sin elementos de señalización, las cuales reciben una única inhumación y una cubrición de tejas, algunas de ellas decoradas (Figs. 12, 13 y 14). Atendiendo a las variantes en la forma general de la fosa distinguimos los siguientes patrones: 


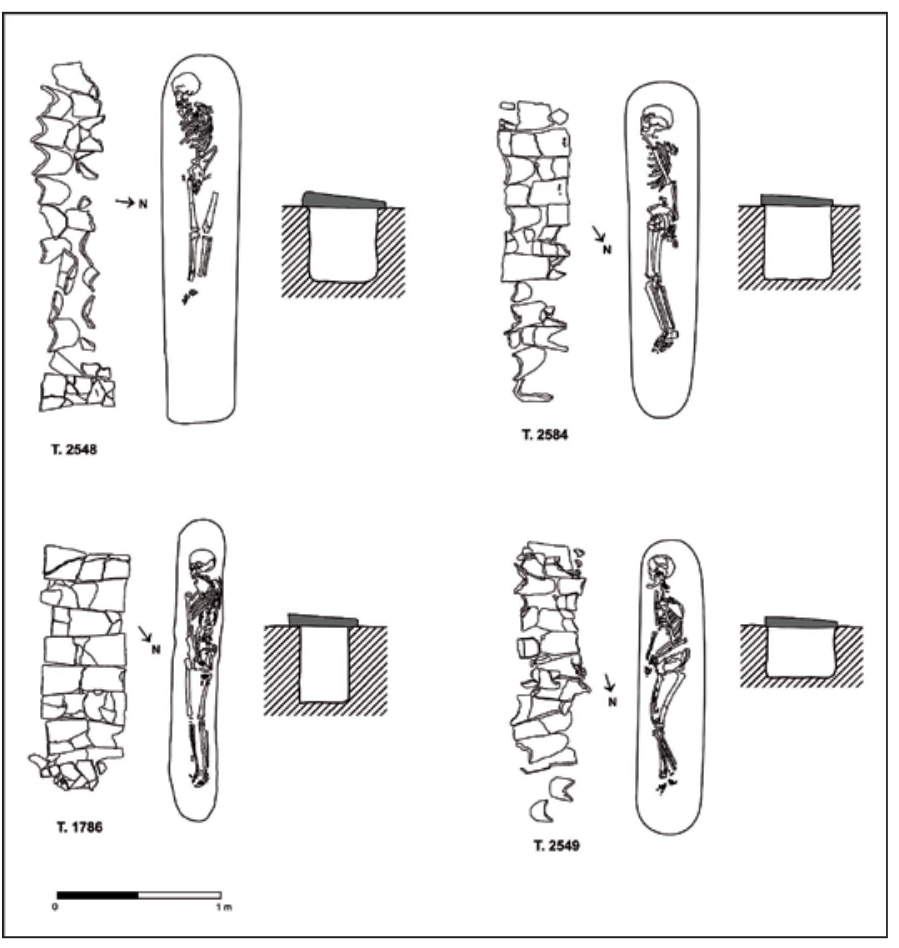

Fig. 12. Plantas y secciones de tumbas en fosa simple.

- Fosa perfectamente rectangular, con cabecera y pies de corte recto (tumbas 1282-E, $1284,1478,1697,1698$ y 1802).

- Fosa con cabecera redondeada (tumbas 1280-E, 1280-O y 2489).

- Fosa con ambos extremos redondeados (tumbas 1283, 1699, 1700, 1786, 2487, 2490, 2549, 2580, 2582, 2583, 2584, 2585 y 2598).

- Fosa más ancha en uno de sus extremos (se dan dos casos en los que existe un ensanchamiento a la altura de las extremidades superiores con una clara adaptación al cadáver) que se va estrechando hacia el extremo opuesto (tumbas 1281, 1282-0 y 1712).

Respecto a las dimensiones de las fosas, predominan las tumbas con longitudes que oscilan entre 1,80 y $2 \mathrm{~m}$, registrándose valores máximos de 2,20 m y mínimos de 1,65 m, mientras que la anchura se sitúa mayoritariamente entre 0,23 y $0,37 \mathrm{~m}$; solo cinco de las fosas alcanzan o superan los 0,40 m de anchura. De los datos de las tumbas cuyos alzados se han conservado completos se obtienen unas profundidades de entre 0,30 y $0,47 \mathrm{~m}$. En cuanto a los enterramientos infantiles, presentan lon- gitudes de 1-1,50 m y anchuras que raramente superan los $0,30 \mathrm{~m}$.

En la mayoría de los registros se tienen evidencias de que las fosas fueron cerradas mediante cubiertas de tejas. Las cubriciones que nos han llegado más completas consisten en una hilada de tejas colocadas transversalmente a la fosa y con su lado cóncavo hacia el interior. Las tejas están dispuestas alternando los extremos mayores y menores para conseguir un cierre más firme. Normalmente aparecen hundidas y fragmentadas hacia la mitad, coincidiendo con el eje longitudinal de la cubierta, debido a un desplome por presión lo que provoca que aparezcan caídas en el interior de la fosa. Sus medidas oscilan entre los 48-45 $\mathrm{cm}$ de longitud, 20-18 cm de anchura en el lado mayory $15-13 \mathrm{~cm}$ de anchura en el menor.

La orientación axial de los enterramientos es invariablemente suroeste-noreste, con la cabecera orientada hacia el suroeste, predominando la tendencia a situar el eje de la tumba en un arco que oscila entre $200^{\circ}$ y $220^{\circ}$ respecto al Norte (85\%), frente a otras orientaciones que superan ambos límites de esta horquilla $\left(185^{\circ}, 190^{\circ}\right.$ y $\left.230^{\circ}\right)$ con una representación de tan solo un 15\% (Tabla 2.)

\subsection{Los rituales de enterramiento}

Con la excepción que hemos apuntado anteriormente, podemos afirmar que el rito practicado mayoritariamente en la necrópolis de La Orden-Seminario nos indica de forma inequívoca la pertenencia al Islam de la comunidad allí enterrada. Como bien es sabido, el ritual funerario musulmán establecía un tratamiento del cadáver en varias etapas que consistían en el lavado del cuerpo del difunto, su amortajamiento y su traslado al cementerio, así como la celebración del banquete funerario y la recitación de oraciones fúnebres durante las siete noches posteriores a la inhumación. La posición del cadáver en el interior 
Tabla 2. Enterramientos de la necrópolis islámica fase II

\begin{tabular}{|c|c|c|c|c|c|c|c|c|c|c|c|c|}
\hline ENT. & POSICIÓN CADÁVER & ORIENT. & SAGITAL & CARA & FOSA & DIMENSIONES (m) & CUBIERTA & $\begin{array}{l}\text { SE } \\
\text { Xo }\end{array}$ & EDAD & $\begin{array}{c}\text { ESTAT. } \\
(\mathrm{m})\end{array}$ & $\begin{array}{c}\text { SUDA } \\
\text { RIO }\end{array}$ & MEDIO \\
\hline $\begin{array}{c}1280 \\
E\end{array}$ & DS Extremidades extendida & SO-NE & $2009 \mathrm{~S}$ & $E$ & $\begin{array}{l}\text { Rect. Cabecera } \\
\text { curva }\end{array}$ & $\begin{array}{c}2,20 \times 0,36 x \\
0,24\end{array}$ & Tejas & $M$ & $\begin{array}{l}\text { Adulto mad. } \\
\text { (43-53 a.) }\end{array}$ & $\begin{array}{c}1,70 \pm \\
6,96\end{array}$ & No & Aerobio \\
\hline $\begin{array}{c}1280 \\
0\end{array}$ & $\begin{array}{l}\text { DLD Extremidades } \\
\text { semiflexionadas }\end{array}$ & SO-NE & $190 \% \mathrm{~S}$ & E & $\begin{array}{l}\text { Rect. Cabecera } \\
\text { curva }\end{array}$ & $\begin{array}{c}1,90 \times 0,40 x \\
0,14\end{array}$ & Tejas & $M$ & $\begin{array}{l}\text { Adulto joven } \\
\text { (36-40 a.) }\end{array}$ & $\begin{array}{c}1,60 \pm \\
6,96\end{array}$ & $\mathrm{Si}$ & Aerobio \\
\hline 1281 & $\begin{array}{l}\text { DLD Brazos semiflexionados } \\
\text { Piernas extendidas }\end{array}$ & SO-NE & $210^{\circ} \mathrm{SO}$ & $\mathbf{E}$ & $\begin{array}{l}\text { Rect. Cabecera } \\
\text { curva }\end{array}$ & $\begin{array}{c}1,65 \times 0,32 x \\
0,13\end{array}$ & - & $\mathrm{F}$ ? & $\begin{array}{l}\text { Adulto mad. } \\
(+40 \text { a.) }\end{array}$ & $\begin{array}{c}1,45 \pm \\
5,96\end{array}$ & Si & Anaerobio \\
\hline $\begin{array}{c}1282 \\
E\end{array}$ & $\begin{array}{l}\text { DLD Brazos y pierna dcha. } \\
\text { ext. Pierna izqda. semiflex. }\end{array}$ & SO-NE & $225 \cong 50$ & S-SE & Rectangular & $\begin{array}{c}1,98 \times 0,33 x \\
0,22\end{array}$ & Tejas & M & Adulto mad. & $\begin{array}{c}1,57 \pm \\
6,96\end{array}$ & No & Aerobio \\
\hline $\begin{array}{c}1282 \\
0\end{array}$ & $\begin{array}{l}\text { DLD Extremidades } \\
\text { extendidas }\end{array}$ & SO-NE & $220^{\circ} \mathrm{SO}$ & SE & $\begin{array}{l}\text { Rect. Cabecera } \\
\text { curva }\end{array}$ & $\begin{array}{c}1,84 \times 0,33 x \\
0,18\end{array}$ & Tejas & M & $\begin{array}{l}\text { Preadulto } \\
(14-15 \text { a.) } \\
\end{array}$ & $\begin{array}{c}1,61 \pm \\
6,96\end{array}$ & $\mathrm{Si}$ & Anaerobio \\
\hline 1283 & $\begin{array}{l}\text { DLD Extremidades } \\
\text { extendidas }\end{array}$ & SO-NE & 220950 & SE & $\begin{array}{l}\text { Rect. Extremos } \\
\text { curvos }\end{array}$ & $\begin{array}{c}1,79 \times 0,32 x \\
0,10\end{array}$ & - & M & $\begin{array}{l}\text { Adulto joven } \\
(+30 \text { a.) }\end{array}$ & $\begin{array}{c}1,64 \pm \\
8,44\end{array}$ & $\mathrm{Si}$ & $\begin{array}{c}\text { Anaeerobi } \\
0\end{array}$ \\
\hline 1284 & $\begin{array}{l}\text { DLD Piernas y brazo dcho. } \\
\text { ext. Brazo izqdo. flexionado }\end{array}$ & SO-NE & $200^{\circ} \mathrm{S}$ & SE & Rectangular & $\begin{array}{c}2,04 \times 0,44 x \\
0,34\end{array}$ & Tejas & M & $\begin{array}{l}\text { Adulto mad. } \\
\text { (43-53 a.) }\end{array}$ & $\begin{array}{l}1,68 \pm \\
6,96\end{array}$ & $\mathrm{Si}$ & Aerobio \\
\hline 1478 & $\begin{array}{l}\text { DLD Brazo y pierna dchos. } \\
\text { ext. izqdos. semiflexionados }\end{array}$ & SO-NE & 210 SO & E & Rectangular & $\begin{array}{c}1,79 \times 0,27 x \\
0,19\end{array}$ & Tejas & $\mathrm{M}$ & $\begin{array}{l}\text { Adulto joven } \\
\text { (36-40 a.) }\end{array}$ & $\begin{array}{c}1,69 \pm \\
6,96\end{array}$ & $\mathrm{Si}$ & Anaerobio \\
\hline 1697 & $\begin{array}{l}\text { DLD Brazos dcho. ext. e } \\
\text { izqdo. flex. Piernas ext. }\end{array}$ & SO-NE & 215? SO & SE & Rectangular & $\begin{array}{c}1,94 \times 0,30 \mathrm{x} \\
0,18\end{array}$ & Tejas & M & $\begin{array}{l}\text { Adulto joven } \\
(25-30 \text { a.) }\end{array}$ & $\begin{array}{l}1,64 \pm \\
6,96\end{array}$ & $\mathrm{Si}$ & Anaerobio \\
\hline 1698 & $\begin{array}{l}\text { DLD Extremidades } \\
\text { semiflexionadas }\end{array}$ & SO-NE & $230 \cong 50$ & SE & Rectangular & $\begin{array}{c}1,52 \times 0,28 \mathrm{x} \\
0,03\end{array}$ & - & A & $\begin{array}{l}\text { Infantil II } \\
(10-12 \text { a.) }\end{array}$ & 1,43 & Si & - \\
\hline 1699 & $\begin{array}{l}\text { DLD Extremidades } \\
\text { extendidas }\end{array}$ & SO-NE & 2259 SO & SE & $\begin{array}{l}\text { Rect. Extremos } \\
\text { curvos }\end{array}$ & $\begin{array}{c}1,73 \times 0,30 \mathrm{x} \\
0,14\end{array}$ & - & $F$ & $\begin{array}{l}\text { Adulto mad. } \\
(45-50 \text { a.) }\end{array}$ & $\begin{array}{c}1,53 \pm \\
7,70\end{array}$ & Si & - \\
\hline 1700 & $\begin{array}{l}\text { DLD Brazo dcho. ext. Izqdo. } \\
\text { semiflex. Piernas semiflex. }\end{array}$ & SO-NE & $1859 \mathrm{~S}$ & $E$ & $\begin{array}{l}\text { Rect. Extremos } \\
\text { curvos }\end{array}$ & $\begin{array}{c}1,40 \times 0,28 \mathrm{x} \\
0,15\end{array}$ & - & A & $\begin{array}{l}\text { Infantil II } \\
\text { (6-7 a.) }\end{array}$ & 1,34 & Si & Anaerobio \\
\hline 1712 & $\begin{array}{l}\text { DS Brazos dcho. extendido } \\
\text { e izqdo. semiflexionado } \\
\text { Piernas extendidas }\end{array}$ & SO-NE & 220950 & E & Rect. Pies curvo & $\begin{array}{c}1,96 \times 0,40 \mathrm{x} \\
0,24\end{array}$ & Tejas & $F$ & $\begin{array}{l}\text { Adulto mad. } \\
(+40 \text { a.) }\end{array}$ & $\begin{array}{l}1,59 \pm \\
5,96\end{array}$ & No & Anaerobio \\
\hline 1786 & $\begin{array}{l}\text { DLD Extremidades } \\
\text { extendidas }\end{array}$ & SO-NE & $215^{9} \mathrm{SO}$ & SE & $\begin{array}{l}\text { Rect. Extremos } \\
\text { curvos }\end{array}$ & $\begin{array}{c}1,98 \times 0,31 X \\
0,47\end{array}$ & Tejas & $\mathrm{F}$ & Adulto mad. & $\begin{array}{c}1,66 \pm \\
5,96\end{array}$ & Si & Anaerobio \\
\hline 1787 & $\begin{array}{l}\text { DLD Brazos semiflexionados } \\
\text { Piernas extendidas }\end{array}$ & SO-NE & $200 \div 5$ & $\mathbf{E}$ & $\begin{array}{l}\text { Rect. Cabecera } \\
\text { curva }\end{array}$ & $\begin{array}{c}(+1,15) \times 0,35 x \\
0,28\end{array}$ & Tejas & $F ?$ & $\begin{array}{l}\text { Adulto joven } \\
(36-40 \text { a.) }\end{array}$ & $\begin{array}{c}1,60 \pm \\
7,70\end{array}$ & $\mathrm{Si}$ & Anaerobio \\
\hline 1802 & $\begin{array}{l}\text { DLD Extremidades } \\
\text { extendidas }\end{array}$ & SO-NE & $210 \% \mathrm{~S}$ & SE & Rectangular & $\begin{array}{c}1,85 \times 0,25 x \\
0,30\end{array}$ & Tejas & $F$ & $\begin{array}{l}\text { Adulto mad. } \\
(40-45 \text { a.) }\end{array}$ & $\begin{array}{l}1,52 \pm \\
5,96\end{array}$ & Si & Anaerobio \\
\hline 2487 & $\begin{array}{l}\text { DLD Extremidades } \\
\text { semiflexionadas }\end{array}$ & SO-NE & $200 \div S$ & SE & $\begin{array}{l}\text { Rect. Extremos } \\
\text { curvos }\end{array}$ & $\begin{array}{c}1,94 \times 0,37 x \\
0,40\end{array}$ & Tejas & $\mathbf{F}$ & Adulto mad. & $\begin{array}{l}1,57 \pm \\
5,96\end{array}$ & Si & - \\
\hline 2489 & $\begin{array}{l}\text { DLD Extremidades } \\
\text { extendidas }\end{array}$ & SO-NE & $210^{\circ} \mathrm{S}$ & SE & $\begin{array}{l}\text { Rect. Cabecera } \\
\text { curva }\end{array}$ & $\begin{array}{c}1,92 \times 0,34 \times \\
0,43\end{array}$ & Tejas & $F$ & $\begin{array}{l}\text { Adulto joven } \\
(20-25 \text { a.) }\end{array}$ & $\begin{array}{l}1,57 \pm \\
5,96\end{array}$ & Si & Anaerobio \\
\hline 2490 & $\begin{array}{l}\text { DLD Extremidades } \\
\text { semiflexionadas }\end{array}$ & SO-NE & $200^{\circ} \mathrm{S}$ & $\mathbf{E}$ & $\begin{array}{l}\text { Rect. Extremos } \\
\text { curvos }\end{array}$ & $\begin{array}{c}1,25 \times 0,34 x \\
0,17\end{array}$ & Tejas & A & $\begin{array}{l}\text { Infantil II } \\
\text { (7-8 a.) }\end{array}$ & 1,14 & No & Aerobio \\
\hline 2549 & $\begin{array}{l}\text { DLD Brazos dcho. ext. Izq. } \\
\text { Flex. Piernas semiflex. }\end{array}$ & SO-NE & $200^{\circ} \mathrm{S}$ & E & $\begin{array}{l}\text { Rect. Extremos } \\
\text { curvos }\end{array}$ & $\begin{array}{c}1,88 \times 0,40 \mathrm{x} \\
0,30\end{array}$ & Tejas & $F$ & Adulto mad. & $\begin{array}{c}1,50 \pm \\
5,96\end{array}$ & Si & Aerobio \\
\hline 2580 & $\begin{array}{l}\text { DLD Brazo dcho. ext. Brazo } \\
\text { izqdo. y piernas flexionados }\end{array}$ & SO-NE & $200^{\circ} \mathrm{S}$ & $\mathbf{E}$ & $\begin{array}{l}\text { Rect. Extremos } \\
\text { curvos }\end{array}$ & $1 \times 0,23 \times 0,05$ & - & A & $\begin{array}{l}\text { Infantil I } \\
\text { (5-7 a.) }\end{array}$ & $\cdot$ & Si & - \\
\hline 2582 & $\begin{array}{l}\text { DLD Extremidades } \\
\text { extendidas }\end{array}$ & SO-NE & $220^{\circ} \mathrm{SO}$ & SE & $\begin{array}{l}\text { Rect. Extremos } \\
\text { curvos }\end{array}$ & $\begin{array}{c}1,95 \times 0,27 \times \\
0,15\end{array}$ & Tejas & M & Adulto ind. & $\begin{array}{l}1,67 \pm \\
6,96\end{array}$ & Si & $\begin{array}{c}\text { Anaerobio } \\
?\end{array}$ \\
\hline 2583 & $\begin{array}{l}\text { DLD Extremidades } \\
\text { semifexionadas }\end{array}$ & SO-NE & $230^{\circ} \mathrm{SO}$ & SE & $\begin{array}{l}\text { Rect. Extremos } \\
\text { red. }\end{array}$ & $\begin{array}{c}1,90 \times 0,26 \mathrm{x} \\
0,28\end{array}$ & Tejas & $M$ & Adulto joven & $\begin{array}{c}1,59 \pm \\
6,96\end{array}$ & $\mathrm{Si}$ & Aerobio \\
\hline 2584 & $\begin{array}{l}\text { DLD Extremidades } \\
\text { extendidas }\end{array}$ & SO-NE & 2059 SO & SE & $\begin{array}{l}\text { Rect. Extremos } \\
\text { curvos }\end{array}$ & $\begin{array}{c}2,10 \times 0,42 x \\
0,45\end{array}$ & Tejas & $\mathbf{F}$ & Adulto mad. & $\begin{array}{c}1,52 \pm \\
5,96\end{array}$ & $\mathrm{Si}$ & Aerobio? \\
\hline 2585 & $\begin{array}{l}\text { DLD Extremidades } \\
\text { extendidas }\end{array}$ & SO-NE & $210^{\circ} \mathrm{S}$ & $E$ & $\begin{array}{l}\text { Rect. Extremos } \\
\text { curvos }\end{array}$ & $\begin{array}{c}1,86 \times 0,35 x \\
0,11\end{array}$ & Tejas & $\mathrm{F}$ & Adulto joven & $\begin{array}{c}1,57 \pm \\
5,96\end{array}$ & $\mathrm{Si}$ & Aerobio \\
\hline 2598 & $\begin{array}{l}\text { DLD Piernas } \\
\text { semiflexionadas }\end{array}$ & SO-NE & $210^{\circ} \mathrm{S}$ & - & $\begin{array}{l}\text { Rect. Extremos } \\
\text { curvos }\end{array}$ & $\begin{array}{c}0,93 \times 0,26 x \\
0,04\end{array}$ & - & A & $\begin{array}{l}\text { Infantil I } \\
\text { (0,5-1 a.) }\end{array}$ & $\cdot$ & No & Aerobio \\
\hline
\end{tabular}

del sepulcro debía permitir que el rostro quedara mirando hacia La Meca, por lo que la sepultura se ubicaba en sentido perpendicular al muro de la qibla ${ }^{9}$, estando terminantemente prohibida la incorporación en su interior de elementos de ajuar o de adornos personales. Como se comprueba en el caso de la necrópolis estudiada, las fosas se excavaban generalmente en el suelo natural, sin ostentar obra de revestimiento hecha de yeso o barro, y no debían ser ni muy superficiales, para evitar la contaminación exterior por efectos de la des- composición del cadáver, ni muy profundas, para que el difunto pudiera incorporarse con el fin de responder a las preguntas que los ángeles de la tumba le realizarían acerca de su fe (CASAL, 2003: pp. 37-42).

El sometimiento a esta rigurosa normativa se hace notar de manera más o menos estricta en los contextos funerarios islámicos de La Orden-Seminario, dando la sensación de una aparente uniformidad ritual. Sin embargo, una lectura atenta de los registros nos permite

9. En al-Andalus se documenta generalmente una orientación en el eje NE-SO (TENDERO, GILABERT y OLCINA, 2007: vol. I, p. 40). 


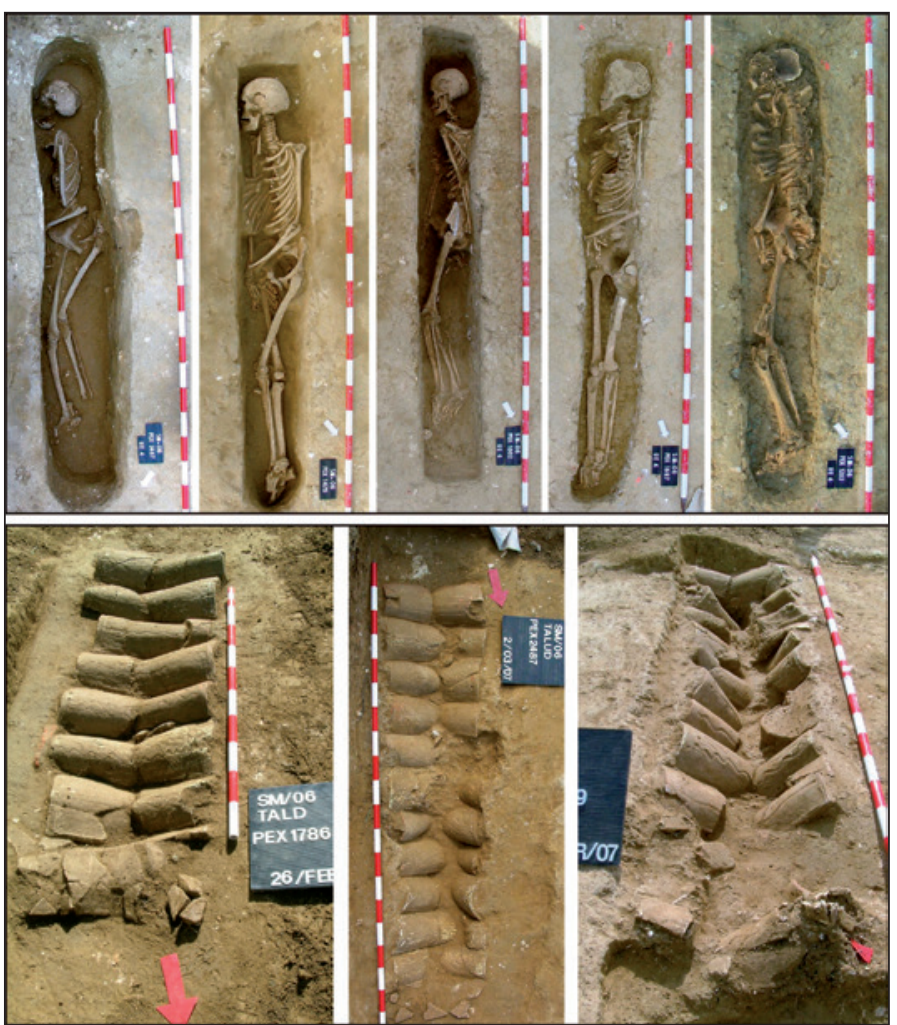

Fig. 13. Enterramientos en fosa simple de la necrópolis islámicall.

claramente el rito islámico, si bien su orientación difiere respecto a la de los sepulcros de la fase II, mostrando valores bastante apartados de la norma canónica, los cuales se incluirían dentro de las orientaciones establecidas a partir de una qibla que M. Rius (2000: pp. 118-120) clasifica como de tendencia Sur (tanto dentro del cuadrante sureste, como del suroeste), que constituyen en definitiva las direcciones menos precisas y rigurosas. Dicha tendencia a orientar las mezquitas hacia el sur predominó en las regiones de Sevilla y Toledo, y específicamente los escasos ejemplos que direccionan hacia el suroeste solo se registran durante los siglos VIII a XI, por lo que esta misma autora supone que debió producirse a lo largo de los siglos una ligera corrección en la disposición de los edificios religiosos (RIUS, 2000: pp. 119-120). En este mismo sentido se expresa A. Jiménez quien manifiesta que las primeras aljamas andalusíes estaban pésimamente orientadas,

apuntar algunas pautas y matices diferenciales que tienen que ver fundamentalmente con la propia evolución de la liturgia funeraria islámica en al-Andalus y con su progresiva expansión y consolidación.

En lo que se refiere a las estructuras pertenecientes a la fase I, debemos indicar que, salvo el caso de la sepultura 2566, los cadáveres de las otras cinco tumbas fueron depositados directamente en la fosa en posición decúbito lateral derecho, siguiendo una orientación general este-oeste y con el rostro dirigido hacia el sur. La disposición de las extremidades ofrece diversas variantes posturales: en las sepulturas 2595, 2596 y 2597 se colocaron semiflexionados brazos y piernas, situándose las manos a la altura de la región púbica; en la tumba 2548 el brazo izquierdo aparece semiflexionado y el brazo derecho y las piernas extendidos; por último, brazos y piernas se emplazaron de manera extendida en el caso de la estructura 1782. Estas cinco inhumaciones reproducen sobre todo debido al reaprovechamiento litúrgico de edificios romanos paleocristianos y visigodos que obligaban a una orientación hacia el sur (JIMÉNEZ, 1991: pp. 196-197), una particularidad que del mismo modo provocaría fluctuaciones e inexactitudes en la orientación de los enterramientos.

Los ejemplos de cementerios hispano-musulmanes que responden a esta tendencia hacia la orientación este-oeste nos remiten, por lo general, a fechas tempranas. En la gran maqbara (Necrópolis 2) de Marroquíes Bajos (Jaén) las sepulturas con orientaciones de $255^{\circ}-285^{\circ}$ representan el $24 \%$ de las tumbas excavadas y se incluyen en la fase I de la necrópolis datada entre la segunda mitad del siglo VIII y la primera mitad del siglo IX, correspondiendo aquéllas a un tipo de tumba compuesta de prefosa y fosa de inhumación central (CASTILLO, NAVARRO y SERRANO, 2011: p. 287). También en Córdoba se encuentran ejemplos de esta adaptación, concretamente en el cementerio de la Ron- 
da Oeste (yacimiento D) que se vincula con la construcción de nuevos arrabales cordobeses a partir de época emiral (CASAL et alii, 2006: pp. 263, 284), así como en la necrópolis de los siglos IX-X hallada en el seguimiento arqueológico del centro comercial Carrefour (CASAL, 2003: pp. 83-89). Entre mediados del siglo VIII e inicios del IX se fechan los enterramientos de rito islámico de variada tipología (fosa simple, prefosa y fosa central, prefosa y cámara lateral) estudiados en la necrópolis de El Soto (Madrid) (VIGIL-ESCALERA, 2015: pp. 254-255). Para la zona emeritense y a partir de las excavaciones desarrolladas en los últimos años en la maqbara de la zona sur de la ciudad, algunos autores han utilizado como criterio cronológico, entre otros indicadores, la orientación de las sepulturas, dejando entrever que, en consideración con la ubicación de las mezquitas, las tumbas islámicas con dirección este-oeste se datarían en época emiral (ALBA, 2005: pp. 338339). En el ámbito provincial citamos el caso de la necrópolis de El camino del Chorrito en Paterna del Campo (Huelva), fechada en un momento impreciso prealmohade (MERCADO et alii, 2001).

Otro de los aspectos que diferencia las tumbas de la fase I de las posteriores documentadas en La Orden-Seminario es su mayor amplitud en la anchura, lo cual debió exigir, en el caso concreto de las sepulturas 2548, 2595, 2596 y 2597 y para evitar desplazamientos o basculaciones post mortem del cuerpo y mantener así la posición preceptiva, el apoyo directo del cadáver sobre la pared norte de la fosa funeraria, una pauta que se testimonia asimismo en cementerios cordobeses (CASAL, 2003: p. 30). La mayor amplitud de las sepulturas se esgrime igualmente como indicador de datación temprana en la mencionada maqbara sur de Mérida (ALBA, 2005: p. 339), en contraste con la evolución posterior de las sepulturas islámicas que se irán haciendo cada vez más estrechas por influencia de la doctrina mālikí, que promovía la realización de fosas estrechas excavadas en el suelo natural, la cual no se verá consolidada en al-Andalus hasta principios del siglo X (TENDERO, GILABERT y OLCINA, 2007: vol. I, p. 36; CASTILLO, NAVARRO y SERRANO, 2011: p. 283).
Aunque la norma del amortajamiento del difunto queda constatada en la mayoría de las tumbas de la fase II, solamente se ha revelado el posible uso de sudario en una de las inhumaciones de este primer conjunto de sepulcros de rito islámico (tumba infantil 2597). Por último, es posible afirmar que, según el estudio antropológico, el ambiente de descomposición de los cuerpos era de tipo aerobio, por lo que se cumplía en todos los casos documentados el precepto coránico de no colmatar las tumbas con tierra (CASAL, 2003: p. 30; TENDERO, GILABERT y OLCINA, 2007: vol. I, pp. 40-41).

Ya hemos señalado en varias ocasiones que la tumba 2566 constituye un caso excepcional dentro de la necrópolis que analizamos, no solo por su particular configuración morfológica (tumba con prefosa y fosa de inhumación central con cubierta de sillares), sino por el diferente ritual de enterramiento practicado en la misma (Fig. 10). Aquí, el individuo inhumado está colocado en posición decúbito supino con piernas extendidas y brazo derecho extendido e izquierdo semiflexionado, con apoyo de ambas manos sobre la zona pélvica. El rostro está dirigido hacia el Este y presenta una orientación de sagital a $260^{\circ}$ respecto al Norte, la cual se presenta acorde con las orientaciones del resto de sepulturas de esta primera fase. Del examen de los restos óseos se plantea que el cadáver fue enterrado probablemente con sudario en un medio aerobio, lo que nos indica que el relleno que presentaba la fosa de inhumación debió filtrarse por entre los huecos de la cubierta de sillares. El conjunto inferior se amortizó finalmente con la misma tierra margosa extraída en el proceso de excavación de la tumba, quedando contenido en los límites de la prefosa, si bien desconocemos si este depósito llegó a formar un túmulo emergente que señalaría la posición del sepulcro, como se documenta en algunas sepulturas de la citada Necrópolis 2 de Marroquíes Bajos (SERRANO y CASTILLO, 2000: f. 8).

Con independencia del tipo de fosa y de sus propios atributos morfológicos, la colocación del cadáver dentro de la sepultura pone de manifiesto que nos encontramos ante un 
enterramiento de rito cristiano, que vendría a representar, en el contexto en el que se enmarca, la manifestación funeraria de una comunidad hispano-visigoda cuyo proceso de islamización aún no habría culminado, pero que podemos valorar, por la excepcionalidad que supone su presencia en este primer momento de la necrópolis, como bastante avanzado, al tiempo que revela, en contra de las prescripciones coránicas que impedían la existencia de cementerios mixtos, la coexistencia de ritos y costumbres funerarios de tradición hispano-romana e islámicos en un mismo espacio mortuorio, una situación que no es en absoluto excepcional en los registros andalusíes (VIGIL-ESCALERA, 2015: p. 266) y que vemos ejemplarizada, por citar dos casos paradigmáticos, en la necrópolis de Tolmo de Minateda (Albacete) (GUTIÉRREZ, 2007: pp. 296-298, f. 4) y en la Necrópolis 4 de Marroquíes Bajos (CASTILLO, NAVARRO y SERRANO, 2011: pp. 278279), ambas de cronología emiral.

Por otra parte, las tumbas con demarcación de prefosa y fosa central quedan atestiguadas a partir de época visigoda, como demuestran los registros de la necrópolis de Gózquez (San Martín de la Vega, Madrid), cuya cronología se sitúa entre el segundo cuarto del siglo VI y mediados del VIII (VIGIL-ESCALERA, 2015: pp. 249253). La continuidad de esta tipología funeraria en los primeros siglos del Islam se reconoce en diversas necrópolis, tanto de rito cristiano, como islámico. En Marroquíes Bajos, como hemos visto, se atestigua desde la fase I de la Necrópolis 2, fechada en época emiral, así como en otras necrópolis cristianas del mismo yacimiento (SERRANO y CASTILLO, 2000: p. 104, f. 8; CASTILLO, NAVARRO y SERRANO, 2011: p. 287). En Mérida, bajo la denominación de "inhumaciones en doble fosa", se tiene documentado este tipo en un área cementerial de rito cristiano que se data en los siglos VIII-IX (DELGADO, 2006: pp. 290, 294). Asimismo, se registran, asociadas a rito islámico, en el conjunto arqueológico de La Rinconada de Olivares (Jumilla) (POZO y HERNÁNDEZ, 1999: p. 422), y, con orientaciones similares a las constatadas para nuestra fase I, en la necrópolis rural del Cabezo del Aljezar (Ricote), un enclave que se identifica con la qarya de Riqut mencionada por el geógrafo cordobés al-Rāzī en el siglo IX (SÁNCHEZ, GALLEGO y BERNAL, 1987: p. 157, f. 1), ambas en la región de Murcia. La pervivencia entre las comunidades cristianas de este tipo sepulcral hasta el siglo XIII, se confirma, según dataciones C14, en la necrópolis mozárabe de Tózar (Moclín, Granada), aunque con la particularidad de que las tumbas de esta necrópolis presentan fosa de inhumación antropomórfica (MATTEI, 2014: p. 192, f. 8).

Tras un amplio intervalo de tiempo, durante el cual se desarrollaron en la zona otros usos de tipo económico, algunas de cuyas manifestaciones estructurales afectan directamente a las sepulturas altomedievales, el espacio funerario volvió a ponerse en funcionamiento con una segunda fase de enterramientos. De este segundo momento de la necrópolis se han documentado un total de 26 fosas de inhumación individuales. Tanto la orientación de las tumbas, en sentido suroeste-noreste, como la disposición de los cadáveres en decúbito lateral derecho, con la cara dirigida al este-sureste, nos indican que nos hallamos ante una comunidad plenamente islamizada. La colocación de los cadáveres es bastante uniforme y no ofrece grandes variaciones, a excepción de los individuos de las tumbas $1280-E$ y 1712 , donde se registra la posición decúbito supino que valoraremos a continuación, ni tampoco se observan importantes desplazamientos post mortem, salvo algunas ligeras basculaciones muy esporádicas, hecho que debemos achacar a una notoria preocupación por mantener al individuo enterrado en la posición correcta, lo cual se ve reflejado en la tendencia a estrechar las fosas, en el uso extendido, según todos los indicios, de sudario ${ }^{10}$ e incluso en la colmatación intencionada del interior de una gran parte de las tumbas. La variación en la colocación de las extremidades no parece responder a una pauta normalizada, si bien

10. De las 26 sepulturas excavadas, se ha podido detectar el posible uso de un sudario o mortaja en 21 de ellas, lo que supone la casi generalización de la práctica del amortajamiento que exige la doctrina islámica. 


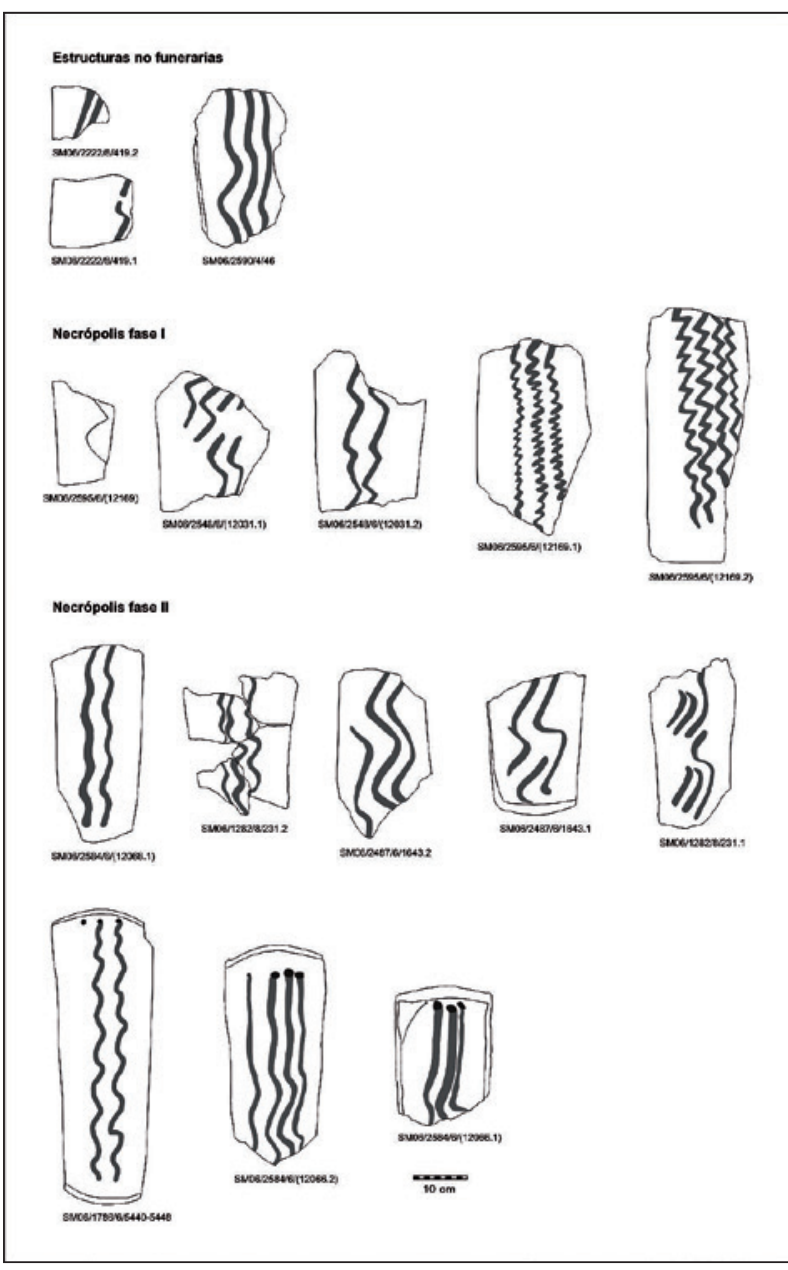

Fig. 14. Esquemas decorativos acanalados en tejas.

predominan los cuerpos que presentan las extremidades completamente extendidas o, por el contrario, ligeramente flexionadas, con casi el mismo número de casos. Otras variantes menos frecuentes consisten en emplazar las extremidades superiores semiflexionadas y las inferiores estiradas; o bien, el brazo derecho extendido y piernas y brazo izquierdo flexionados; también encontramos casos en los que el brazo derecho y las piernas se colocan extendidos, mientras que el brazo izquierdo se dispone flexionado. Cuando existe flexión de las extremidades superiores, las manos suelen aparecer situadas en la zona pélvica.

Cabe afirmar que la variante en decúbito supino, que registramos en las sepulturas 1280-E y 1712, ha sido ampliamente documentada, junto con otras desviaciones posturales, en distintos cementerios andalusíes con contextos funerarios islámicos de estricta ritualización, y en su explicación se aducen, tanto razones tafonómicas o postdeposicionales, como la dificultad de disponer adecuadamente el cadáver en la sepultura a consecuencia del rigor mortis (TENDERO, GILABERT y OLCINA, 2007: p. 40). En nuestro caso, la postura del esqueleto de la tumba 1280-E presenta mayor apoyo en su lado derecho, por lo que es probable que se produjera un desplazamiento del cuerpo hacia la supinación a consecuencia de la descomposición aérea del cadáver. Respecto a la sepultura 1712, el apoyo del cadáver en la pared norte de la fosa y el medio donde se halla, de tipo anaerobio, nos lleva a pensar que existieron importantes dificultades para situar adecuadamente el cuerpo. En ambos enterramientos, la cabeza se encuentra ladeada hacia la derecha y el rostro está orientado hacia el Este, con lo que se disipa cualquier duda sobre la adscripción religiosa de los individuos inhumados.

La norma de no rellenar con tierra el interior de la sepultura no se cumple estrictamente en los enterramientos de esta segunda fase. Más de la mitad de los registros en que se ha podido determinar el medio de descomposición del cadáver (46\% del total de tumbas) se corresponden con fosas en las que se produjo una colmatación intencionada de su interior. Esta práctica se comprueba físicamente en algunas tumbas por el hecho de no presentar caída o hundimiento de la cubierta de tejas hacia el hueco de la fosa mortuoria. Refleja, en todo caso, la relajación o permisividad en cuanto a la obligatoriedad de cumplir con la norma coránica, visible en algunos otros aspectos en diversas necrópolis de al-Andalus (TENDERO, GILABERT y OLCINA, 2007: p. 41).

Como hemos visto anteriormente, en la fase II de la necrópolis no se documentan tumbas con orientación este-oeste, sino que se generaliza la tendencia a orientar los enterramientos en sentido suroeste-noreste, resultando una orientación mucho más exacta en relación con 
la dirección a La Meca. La orientación preferente y mayoritaria de $200^{\circ}-220^{\circ}$ respecto al Norte de las sepulturas excavadas toma como referencia una qibla que tiende a dirigirse hacia el Este. En esta tendencia se incluye un conjunto de mezquitas andalusíes de los siglos X a XIV cuya orientación parece deberse al orto del sol en invierno, que en al-Andalus se situaría en torno a los $120^{\circ}$ (RIUS, 2000: pp. 106-110), lo que supone una mejora significativa respecto a las orientaciones anteriores al siglo X (JIMÉNEZ, 1991: p. 197). Dentro de este espectro de orientaciones se sitúan, tanto enterramientos con prefosa y fosa central de la fase II de Marroquíes Bajos, como de fosa simple de la fase III, con cronologías de los siglos IX-X y XII-XIII, respectivamente (CASTILLO, NAVARRO y SERRANO, 2011: pp. 287-288).

Hay que señalar que en ninguna de las estructuras funerarias de La Orden-Seminario, incluyendo las dos fases, se han documentado elementos de ajuar que acompañaran los cuerpos. Esta es una característica común a la gran mayoría de necrópolis islámicas, debido sobre todo a que el ritual funerario musulmán es muy claro con respecto a la austeridad de los enterramientos y la debida ausencia de ningún tipo de ostentación u ornamentos. Tampoco se ha detectado la presencia de clavos que pudieran ponerse en relación con el uso de algún tipo de contenedor funerario de madera (ataúd o parihuela). El único elemento de esta naturaleza constatado es un clavo de hierro de cabeza cuadrada, recuperado en el relleno de la fosa de la tumba 1786, que puede ser perfectamente interpretado como una inclusión contenida dentro de la tierra vertida en el interior de la sepultura en el momento de la inhumación.

Respecto a la estructuración interna de la necrópolis en este momento, hemos de señalar que, aunque no se hayan reconocido espacios individualizados para cada sexo, o específicos para las inhumaciones infantiles, resulta curiosa, no obstante, la existencia de una mayor concentración de inhumaciones femeninas e infantiles en el conjunto de tumbas más occidental, contabilizándose en ese sector un total de seis mujeres y tres niños de menos de 8 años frente a dos individuos masculinos.

Las características morfológicas de las tumbas y el ritual de enterramiento registrados en las sepulturas de esta fase II han sido sobradamente documentadas en multitud de maqābir hispano-musulmanas enmarcadas dentro de las prescripciones coránicas. En cuanto al tipo concreto de fosa simple con cubierta de tejas que se atestigua en ambas fases en La Orden-Seminario (Figs. 12 y 13), se encuentran igualmente numerosos ejemplos que abarcan todo el periodo de dominación musulmana: $M^{a}$. T. Casal lo incluye en el subtipo 1.2. de su estudio sobre los cementerios islámicos de Córdoba, que define como un modelo muy común y duradero en el tiempo (CASAL, 2003: pp. 131-133); en Málaga, se documentan en el primer nivel de enterramientos de la maqbara de Ŷabal Fāruh (tumba tipo G), fechado en el siglo X (FERNÁNDEZ, 1995: p. 44), y en Marroquíes Bajos se adscriben a la fase III de la Necrópolis 2 (fosa variante B) que se data entre el siglo XII y la primera mitad del siglo XIII (SERRANO y CASTILLO, 2000: p. 104).

Gran número de las tejas utilizadas para la construcción de las cubiertas de las estructuras funerarias aparecen decoradas con motivos acanalados mediante técnicas de digitación, formando líneas curvas o meandros siguiendo su eje mayor. El número de estos varía entre dos y cuatro, cuyas ondas pueden presentarse más o menos pronunciadas (Fig. 14). Este tipo de decoraciones en estos elementos constructivos se han estudiado mayormente en estructuras arquitectónicas en ámbitos rurales, como es el caso del yacimiento de La Caserona (Teba, Málaga) (SUÁREZ et alii, 1999: f. 8) correspondiente a una alquería de época emiral y donde se han relacionado estos motivos con signos zodiacales como el de Acuario, aunando una funcionalidad puramente decorativa con cierta función protectora o propiciatoria (SUÁREZ et alii, 1999: p. 436). La importancia de la astrología en época Omeya en los sistemas constructivos es bien conocida, como ponen de manifiesto varios autores, tales como Maslama al-Maŷrīīi en su Libro de 
Picatrix, según cita recogida por M. Acién (1995: p. 189): "en la construcción de las ciudades hay que utilizar las estrellas y en la construcción de las casas los planetas...".

No obstante, el uso de estos motivos decorativos de carácter simbólico no es un rasgo novedoso ni exclusivo del período islámico y encontramos precedentes en yacimientos hispano-visigodos de la Meseta como el de Frontera de Portugal (Madrid) (SÁNCHEZ y GALINDO, 2006: f. 6) donde se han documentado tejas decoradas asociadas a techumbres de cabañas fechadas en la segunda mitad del siglo VII y primera del VIII, y en localizaciones portuguesas como el yacimiento de Cabeçana 4 (Alqueva) (GRILO, GÓMEZ y MARQUES, 2015: p. 205), o los localizados en el concelho de Castelo de Vide (CUESTA-GÓMEZ, RAMOS y PRATA, 2018, fs. 2, 3), que se corresponden con poblaciones rurales cuya cronología abarca desde el siglo V al VIII.

Paralelos formales para este tipo de decoraciones en las tejas en cuanto a ámbitos cementeriales los encontramos en la necrópolis hispano-musulmana de la Sierra de la Utrera (Málaga), asociada a una alquería fortificada de larga perduración (siglos IX al XIII), donde también han aparecido tejas decoradas con meandros (FERNÁNDEZ, SALADO y SUÁREZ,
2001: p. 81), así como en la necrópolis de los siglos IX-X de Fuente Álamo (Puente Genil) ${ }^{11}$.

En todos los casos, los motivos decorativos de estos elementos son casi idénticos a los que aparecen en muchas de las tejas que componen las cubiertas de las estructuras funerarias de La Orden-Seminario, y si bien se trata mayoritariamente de elementos asociados a la construcción de techumbres, la hipótesis de su uso y funcionalidad de carácter simbólico y protectora bien podría trasladarse a las necrópolis donde aparecen tejas decoradas que componen las cubiertas de las tumbas, otorgando protección a los difuntos, más aún teniendo en cuenta que Acuario es el signo del agua, elemento purificador para todas las culturas y que puede asociarse perfectamente con el mundo funerario islámico con un sentido profiláctico y apotropaico.

\section{ASPECTOS ANTROPOLÓGICOS Y PALEODEMOGRÁFICOS DE LOS RESTOS ÓSEOS DE LA NECRÓPOLIS HISPANO-MUSULMANA}

Como hemos apuntado al principio, los datos antropológicos que se detallan en este apartado han sido extraídos de los informes técnicos aportados por la investigadora Inma-

Tabla 3. Distribución paleodemográfica por categorías de edad de la necrópolis islámica fase I

\begin{tabular}{|c|c|c|c|c|}
\hline $\begin{array}{c}\text { LA ORDEN-SEMINARIO } \\
\text { ISLÁMICO FASE I }\end{array}$ & Total & Masculino & Femenino & Alofiso \\
\cline { 2 - 5 } $\mathbf{N}^{\mathbf{0}}$ & $\mathbf{N}^{\mathbf{0}}$ & $\mathbf{N}^{\mathbf{0}}$ & $\mathbf{N}^{\mathbf{0}}$ \\
\hline Neonato & 0 & - & - & - \\
\hline Infantil I (0-6 años) & 2 & - & - & 2 \\
\hline Infantil II (7-12 años) & 0 & - & - & - \\
\hline Juvenil (13-20 años) & 0 & - & - & - \\
\hline Adulto joven (21-40 años) & 3 & 2 & - & 1 \\
\hline $\begin{array}{c}\text { Adulto maduro (41-60 } \\
\text { años) }\end{array}$ & 0 & - & - & - \\
\hline Adulto indeterminado & 1 & - & 1 & - \\
\hline Senil (+60 años) & 0 & - & - & - \\
\hline Total individuos & 6 & 2 & 1 & 3 \\
\hline
\end{tabular}

11. http://www.puente-genil.es/Ftealamo/Falamo04.htm (consultado el 18/07/2017). 
culada López Flores, encargada de la coordinación de los trabajos de excavación arqueológica de las estructuras funerarias y responsable de los análisis antropológicos posteriores.

En relación a la información antropológica de los enterramientos altomedievales o fase I, se han documentado un total de 6 individuos distribuidos según se indica en la Tabla 3.

Aunque los datos son muy escasos para realizar valoraciones generales, y teniendo en cuenta que, a excepción de la tumba 2595, el resto aún no ha sido estudiado en laboratorio, podemos decir que los adultos registrados no pasan la madurez (40 años). El estudio de laboratorio del individuo adulto joven masculino de la tumba 2595, evidencia algunos aspectos morfológicos hereditarios localizados en los pies: presencia de huesos sesamoideos y doble faceta calcáneo astragalina; así como el hecho de una actividad repetitiva ejercida con las manos y que implica la flexión y extensión de los dedos (flexor común de los dedos). Esos mismos rasgos morfológicos se combinan con una patología articular bastante importante (teniendo en cuenta la edad) en codo y en la columna vertebral, así como signos de estrés nutricional desarrollado en la infancia (y reflejado en los dientes) y una salud dental deficiente.
Por otro lado, debemos destacar en este grupo la posible fractura de tibia y peroné de un individuo de entre 5 y 7 años, que sería necesario comprobar con un estudio más en detalle.

A pesar de la muestra reducida, se puede avanzar que la estatura media masculina ronda $1,65 \mathrm{~m}$, mientras que el único individuo femenino tiene una talla ligeramente inferior: $1,63 \mathrm{~m}$

En lo que se refiere a la fase II de la necrópolis, la población inhumada se compone de 26 individuos, de ambos sexos y de edades muy diversas, cuya distribución y relación porcentual se presentan en la Tabla 4.

La distribución por categorías etarias (desde individuos infantiles hasta adultos maduros) refleja una dinámica demográfica que perfectamente podría asociarse a una población o comunidad estable, con una presencia importante del sector infantil $(19,23 \%)$ y de población adulta madura. La madurez es alcanzada ya por un grupo más numeroso (11 individuos mueren con más de 40 años, lo que supone el 42,30\% del total de la población), siendo característico en este tramo de edad el predominio de la población femenina. Si atendemos a la distribución de la población según sexo se

Tabla 4. Distribución paleodemográfica por categorías de edad de la necrópolis islámica fase II

\begin{tabular}{|l|c|c|c|c|c|c|c|c|}
\hline \multicolumn{1}{|c|}{$\begin{array}{c}\text { LA ORDEN- } \\
\text { SEMINARIO } \\
\text { ISLÁMICO FASE II }\end{array}$} & \multicolumn{2}{|c|}{ Total } & \multicolumn{2}{c|}{ Masculino } & \multicolumn{2}{c|}{ Femenino } & \multicolumn{2}{c|}{ Alofiso } \\
\hline Neonato & 0 & 0 & - & 0 & - & 0 & - & 0 \\
\hline Infantil I (0-6 años) & 2 & 7,69 & - & 0 & - & 0 & 2 & 7,69 \\
\hline Infantil II (7-12 años) & 3 & 11,53 & - & 0 & - & 0 & 3 & 11,53 \\
\hline Juvenil (13-20 años) & 1 & 3,84 & 1 & 3,84 & - & 0 & - & 0 \\
\hline $\begin{array}{l}\text { Adulto joven (21-40 } \\
\text { años) }\end{array}$ & 8 & 30,80 & 5 & 19,23 & 3 & 11,53 & - & 0 \\
\hline $\begin{array}{l}\text { Adulto maduro } \\
\text { (41-60 años) }\end{array}$ & 11 & 42,30 & 3 & 11,53 & 8 & 30,80 & - & 0 \\
\hline $\begin{array}{l}\text { Adulto } \\
\text { indeterminado }\end{array}$ & 1 & 3,84 & 1 & 3,84 & - & 0 & - & 0 \\
\hline Senil (+60 años) & 0 & 0 & - & 0 & - & 0 & - & 0 \\
\hline Total individuos & 26 & 100 & 10 & 38,46 & 11 & 42,30 & 5 & 19,23 \\
\hline
\end{tabular}


comprueba que los porcentajes dan una ligera prevalencia de individuos femeninos en el total de la población. De esta manera, la población sexada femenina alcanza el 42,30\%, frente al 38,46\% de individuos masculinos. Es significativa la reducción del grupo adulto maduro masculino con un porcentaje del $11,53 \%$, mientras que las mujeres están representadas en este tramo de edad por un elevado $30,80 \%$.

Con respecto a los aspectos morfológicos y patológicos de la población inhumada en la fase II, los resultados se multiplican gracias al número de inhumaciones registradas y al buen estado de conservación de los esqueletos, además de que el estudio de laboratorio pudo realizarse sobre 16 individuos.

El análisis antropológico ha revelado variantes anatómicas no métricas o de carácter epigenético presentes en la población, a partir de las cuales es posible sugerir vínculos de parentesco entre los individuos inhumados. Dichos rasgos no métricos se han conservado en 14 individuos, siendo los que más incidencia tienen, observados tanto en hombres como en mujeres, los siguientes: huesos sesamoideos en pies (9 casos), huesos wormianos lambdoideos (4 casos), perforación olecraniana bilateral (3 casos) y doble faceta calcáneo astragalina (2 casos). En una sola ocasión se constatan otras variantes como son la patella bipartita, la sacralización lumbar o la presencia de huesos sesamoideos en manos. Destacamos entre todos, los tres casos de perforación olecraniana del húmero que, siendo una característica casi exclusiva femenina, en esta ocasión se documenta en tres individuos masculinos, pudiendo estar ante un rasgo caracterizador poblacional. En cualquier caso, la muestra es muy escasa, aunque el dato es bastante significativo.

El estudio realizado ha identificado rasgos funcionales, que podrían señalar signos de actividad, en 11 individuos, de los cuales 6 son masculinos y 5 femeninos. Los datos permiten reconocer un patrón de actividad que, junto con la presencia de determinadas patologías, sugieren situaciones de esfuerzo laboral. La diferenciación entre hombres y mujeres se evidencia quizás en una mayor incidencia de los indicadores de estrés en el esqueleto apendicular superior masculino, lo cual implicaría una mayor actividad con los brazos, y en que la distribución anatómica de los marcadores es mucho más variada que en los individuos femeninos.

Como dato morfológico relevante comentaremos que el índice de aplanamiento del fémur o platimeria se distribuye tanto en individuos femeninos como en masculinos, así como las facetas de acuclillamiento (uno femenino y dos masculinos). También interesante a título individual es el desgaste anómalo de los incisivos del joven masculino del enterramiento 1280-0.

En lo que se refiere a las patologías documentadas, el gran número de individuos que presentan alteraciones odontológicas (23), osteoarticulares (16), traumáticas (10) y carenciales (6), está en relación directa, tanto con el grado de madurez de la misma, como con el grado de estudio de la muestra. En cualquier caso, es significativa la abundancia en lesiones en relación al número de individuos analizados.

Entre las patologías más frecuentes en la comunidad islámica de La Orden-Seminario se encuentran las buco-dentales, con una presencia mayoritaria de caries, cálculos y pérdidas dentarias ante mortem que son exponentes de la mala situación higiénico-bucal de la población; en el caso de las lesiones cariosas, presentes incluso en individuos infantiles, estas se asocian al excesivo contenido en carbohidratos de la dieta alimenticia, que estaría basada fundamentalmente en el consumo de alimentos vegetales cocidos, ricos en azúcares e hidratos de carbono (ARAN, 2012: p. 79), aspecto este que sugiere un limitado acceso a los recursos alimenticios.

En un segundo lugar de prevalencia se encuentran las lesiones osteoarticulares, de nuevo en directa relación con la edad de los individuos estudiados; si bien hay segmentos comunes a los dos sexos (columna lumbar, cadera, pies y manos), entre los individuos fe- 
meninos hay más zonas anatómicas afectadas. Por otro lado, hemos de tener en cuenta que la actividad física, los movimientos repetitivos (como algunos de tipo laboral) o posturas forzadas provocan este tipo de patologías como compensatorias o secundarias al requerimiento muscular de los individuos.

Los procesos traumáticos afectan en mayor medida a la población masculina (7 individuos masculinos frente a 3 femeninos). Existe una mayor incidencia de hernias discales e intracorporales en hombres, algunos de ellos muy jóvenes, mientras que las fracturas en clavícula, costillas y esqueleto apendicular superior quedan más igualadas. Este tipo de lesiones (hernias, osteocondritis o microtraumas e incluso fracturas de costillas) están muy relacionadas con las condiciones de vida cotidiana, siendo realmente abundantes para la población que manejamos. Denotan unas duras condiciones de vida, dado que, por lo general, se asocian a sobrecarga de tipo muscular. Por otra parte, la prevalencia de estos procesos traumáticos en hombres redunda en la idea de un componente funcional diferencial.

Otro tipo de traumas, los directos como las fracturas, también están presentes, indicando hechos particulares, como la fractura de cúbito de un individuo femenino (Tumba 1802) relacionada con una reacción de tipo reflejo a la autodefensa, o la de radio de un individuo joven masculino (Tumba 1283) que puede deberse a una caída.

Entre las enfermedades metabólicas se documenta la hipoplasia del esmalte, constatada en dos individuos, uno de ellos alofiso de 10-12 años, y otro masculino de 25-30 años, la cual está muy relacionada con periodos críticos de malnutrición y es un claro indicador de la calidad de vida del individuo. Dos individuos femeninos presentan evidentes signos de osteoporosis, claramente relacionado con la edad y el proceso menopáusico.

Como patología de origen tumoral aislada se ha diagnosticado un encondroma en la IV falange proximal de la mano izquierda de un individuo masculino con una edad entre 36 y 40 años, caso que fue expuesto en un foro específico de ámbito nacional (POLO y LÓPEZ, 2009).

Se realizó también el estudio métrico y descriptivo de un total de 9 cráneos con el objeto de determinar las variantes morfológicas de la población inhumada. Aunque en la mayoría de los casos analizados se detectan características del tipo mediterráneo grácil, no obstante, la mayor aportación del estudio radica en la identificación de fenotipos diferentes de la población mayoritaria. Se trata de los cuerpos inhumados en los enterramientos 1280-0 y 1282-0, cuyas características craneales presentan un cierto componente negroide, hecho que vendría a testimoniar la presencia aparente de individuos de origen africano en la población islámica de La Orden-Seminario ${ }^{12}$. No se constata, sin embargo, ninguna relación entre el origen poblacional y el ritual de inhumación; tampoco la información sobre patologías y estrés músculo-esquelético de estos dos individuos masculinos parecen indicar unas condiciones de vida diferentes a las del resto, con lo que no podemos citar indicadores de diferenciación social motivados por el origen étnico.

Finalmente, la estimación de la talla de esta población establece valores medios de 1,64 m para el sexo masculino y de $1,55 \mathrm{~m}$ para el grupo de individuos femeninos.

12. Existen otros casos que certifican la presencia de grupos poblacionales de origen africano en la Península Ibérica. Uno de los más reveladores, por tratarse de un momento tan temprano como es la fase de conquista, lo encontramos en la maqbara de Pamplona, donde se han identificado manipulaciones intencionales en los dientes de un número importante de individuos, las cuales se han relacionado con prácticas culturales propias de poblaciones africanas (DE MIGUEL et alii, 2016). Para un momento más avanzado de la presencia islámica, se cita otro caso de manipulación dental en la necrópolis de Puerta Elvira (Granada); a tenor de las características antropológicas del individuo en cuestión, se ha propuesto un origen subsahariano (GONZALO et alii, 2003: p. 363). Igualmente, a partir de la información antropométrica se ha detectado la presencia de individuos negroides en diversos yacimientos andalusíes, tales como Medina Ilvira (ROMÁN, 2013: p. 156), poblado de La Torrecilla (Arenas del Rey, Granada) (DU SOUICH y RUIZ, 1996) y Marroquíes Bajos (ARAN, 2012: p. 79), entre otros. 


\section{CONSIDERACIONES FINALES}

Los datos y la información expuestos en los apartados anteriores nos permiten establecer una serie de consideraciones finales que, a modo de esbozo general, pretenden ser una aportación al conocimiento de un periodo escasamente tratado por la investigación arqueológica onubense. Sin duda, los restos arqueológicos estudiados en el yacimiento de La Orden-Seminario se convierten en un valioso instrumento para la caracterización material y cultural de la sociedad islámica y posibilitan el reconocimiento de determinados elementos que son indicadores del proceso de islamización experimentado por las poblaciones tardoantiguas afincadas en el hinterland de la ciudad de Huelva.

Como hemos ido viendo a lo largo de este trabajo, los testimonios materiales de las épocas tardorromana y visigoda, aun cuando escasos en sus momentos iniciales, constituyen el punto de partida a partir del cual podemos explicar la posterior evolución histórica acontecida en el ámbito extraurbano y agrícola de La Orden-Seminario. Gracias a las últimas investigaciones realizadas especialmente en la periferia del casco urbano de Huelva, es posible admitir la existencia de un cierto decaimiento de la vieja ciudad romana a partir del siglo IV, al tiempo que queda evidenciado un considerable florecimiento de los asentamientos rurales en la zona de campiña contigua al núcleo urbano, dedicados a la explotación de los recursos marítimos y agrícolas, cuya actividad se mantiene, en algunos casos, hasta bien entrado el siglo VI (BERMEJO y CAMPOS, 2014: p. 289). Enclaves con contextos tardíos, comprendidos todos en el arco norte de la ciudad actual, tales como La Orden (O ' KELLY, 2012), El Cabezo de la Almagra (VIDAL et alii, 2013), Peguerillas II (CAMPOS, 2009: p. 149), El Torre- jón (CARRIAZO, 2006), finca Nuestra Señora del Rocío (AMO, 1976, pp. 110-112) y el propio yacimiento de La Orden-Seminario, compendian una realidad socio-económica -afianzamiento de los centros de producción y explotación agropecuarios al amparo de una próspera nobleza rural, proliferación de los cementerios extraurbanos, drástica disminución de la dinámica comercial- (O ' KELLY, 2012: p. 293; BERMEJO y CAMPOS, 2014: p. 290) que, en consonancia con la evolución histórica reconocida en otras zonas de la Tierra Llana onubense (villa de Cantarranas y Los Bojeos en Niebla) (PÉREZ, 2004a), constituyen la expresión de un proceso de regresión urbana y sugieren una aparente decadencia de la vida municipal ${ }^{13}$. Esta ruptura se deja sentir en el propio núcleo urbano con la desaparición de toda huella de actividad constructiva o de ocupación efectiva más allá del siglo $V$, una pauta que, en base a los registros arqueológicos y a las fuentes textuales disponibles, se mantiene casi inalterable durante toda la Alta Edad Media (GARCÍA, 2002: p. 39; CAMPOS, 2005: p. 68; DELGADO, 2016: pp. 769, 935).

Tomando como punto de partida dicho contexto histórico-arqueológico y para explicar la presencia de los cementerios medievales en este sector del yacimiento, hemos ya planteado, tanto en este como en un trabajo anterior (BATANERO, BELTRÁN y VERA, 2016: p. 123), la hipótesis de la existencia de una posible villa rustica romana en el origen de la ocupación de la zona. Asumiendo el paralelismo con el modelo de evolución constatado en el sitio del Cabezo de la Almagra (VIDAL, GÓMEZ y CAMPOS, 2003), la instalación romana podría haber evolucionado con el tiempo hasta su transformación en alquería islámica, quedando finalmente fosilizadas ambas construcciones en el recientemente demolido cortijo de Nuestra Señora del Rocío, situado en el entorno inmediato

13. En otros contextos de la provincia de Huelva, concretamente en el territorio de la antigua Ilipla romana (Niebla), los datos aportados por la investigación arqueológica ponen de manifiesto igualmente la pérdida de importancia del espacio urbano en contraposición con el nuevo impulso que adopta el mundo rural, ámbito desde el cual las élites tardoantiguas parecen asumir las funciones administrativas y religiosas desempeñadas anteriormente por las instituciones municipales (CAMPOS, GÓMEZ y PÉREZ, 2006: p. 356). Como ejemplo paradigmático de este proceso de ruralización y florecimiento de la nobleza rural se cita el mencionado asentamiento de Los Bojeos (Bonares), que, asumiendo las funciones de culto, enterramiento y producción, refleja las nuevas dinámicas de articulación del territorio que caracterizarán la Tardoantigüedad (PÉREZ, 2004a; BERMEJO y CAMPOS, 2014, 290). 
a las necrópolis tardoantigua e islámicas. Esta propuesta se apoya también en la ubicación estratégica de la villa-alquería-cortijo en una de las principales vías de acceso a la ciudad, siguiendo un patrón de poblamiento rural articulado originalmente en torno a las calzadas que discurrían por el territorio agrícola de Onoba en dirección a su núcleo urbano, una red viaria que en parte ha quedado retratada en la caminería reciente (DELGADO, 2016: p. 846, f. 590).

Hasta el momento no tenemos constancia física y tangible de dicho establecimiento rural de época romana, salvo el material constructivo secundario contenido principalmente en estructuras negativas de adscripción islámica, si bien se han documentado numerosas zanjas de demarcación o de irrigación, silos de almacenamiento de grano y piedras de molino de tipo rotatorio (catillus y meta), que evidencian, al menos desde época bajoimperial, la intensa explotación agrícola de este espacio, configurado sin lugar a dudas como un paisaje agrario estructurado, presumiblemente delimitado y parcelado, que albergaría también en un momento tardío su propia área funeraria. La necrópolis hispano-visigoda de La Orden-Seminario (2a mitad s. VI-s. VII) confirma por tanto la vigencia de este esquema de poblamiento rural heredado de siglos anteriores y ejemplifica la consolidación y extensión de una clase productora campesina como base poblacional de un sistema socio-económico cuya cúspide política está ocupada por una poderosa nobleza relacionada con importantes posesiones rurales y estrechamente ligada a la jerarquía eclesiástica. Frente a las humildes tumbas de La Orden-Seminario, donde si acaso destaca algún individuo relacionado con actividades artesanales (BATANERO, BELTRÁN y VERA, 2016: f. 3), encontramos que los miembros de estas élites hispano-romanas utilizan suntuosos sarcófagos para su enterramiento, como es el caso del obispo iliplense Vincomalos y de otro destacado personaje llamado Murensis, ambos inhumados en lo que pudo ser una villa aulica o basílica rural dependiente del episcopado de Niebla (PÉREZ, 2004a: pp. 35-36; GONZÁLEZ, 2004: pp. 59-60; BERMEJO y CAMPOS, 2014: p. 288).
Al margen de la práctica cementerial normalizada que representa la necrópolis para la comunidad rural de época visigoda, los registros funerarios altomedievales de La Orden-Seminario constatan, por otra parte, el único caso de inhumación anómala en el interior de silo atestiguado por el momento en la provincia Bética, el cual adquiere una especial importancia dado el significado social que, a la luz de otras investigaciones, puede inferirse de su estudio. Como hemos señalado líneas atrás, la estructura 2222/E-1 certifica el final del periodo visigodo e inaugura la transición al mundo islámico. Su importancia arqueológica reside en que, por un lado, nos permite reconocer los repertorios ergológicos que estaban vigentes en la fase tardovisigoda, a partir de los cuales resultaría factible definir y delimitar a nivel material el momento de tránsito a la etapa andalusí; de otro lado, nos ofrece un caso excepcional de inhumación extracementerial cuya interpretación, no solo desde el punto de vista de su significación ritual o funeraria, sino también en términos sociales, permitiría otorgar cierta continuidad a la configuración social de los grupos inferiores de la sociedad hispano-visigoda, así como a concretar los posibles indicadores arqueológicos para su identificación.

Atendiendo a los primeros, el análisis de los contextos cerámicos estratificados de esta y otras estructuras siliformes relacionadas pone de manifiesto el absoluto dominio de las cerámicas elaboradas a mano o a torneta de marcada tradición hispano-visigoda. Habida cuenta de la excepcionalidad que suponen los escasos materiales importados desde ámbitos lejanos, estas producciones apuntarían hacia una manifiesta simplificación de los ciclos de fabricación artesanales y de las redes de distribución, haciéndose patente la tendencia a la autosuficiencia económica en un entorno estrictamente aldeano y agrario.

Con respecto al depósito humano localizado en el interior del silo, cabe decir que constituye una práctica de enterramiento producida en silos y pozos de desechos al margen de la norma ritual cementerial, que ha suscitado recientemente un intenso debate acerca de la 
posibilidad de reconocer arqueológicamente a individuos marginados de la sociedad hispano-visigoda. La mayoría de los casos que se han documentado en cuanto a estas prácticas poco convencionales y que no son atribuibles a rito funerario alguno, se localizan en asentamientos rurales y poblados agrícolas de la Meseta Central y Cataluña con fechas de los siglos VI a VIII, y engloban a individuos adultos e infantiles de ambos sexos, tanto de manera individual, como colectiva. Los depósitos presentan conexiones anatómicas forzadas y peculiares, probablemente como consecuencia del arrojamiento indiscriminado de los cuerpos al interior de las estructuras, careciendo aparentemente de cualquier tipo de tratamiento o ritual funerario explícito. En atención a las características de estos depósitos humanos anómalos y de su contexto, algunos investigadores consideran que estos casos se asocian a prácticas de exclusión social que conllevan un trato diferencial y discriminatorio de determinados individuos con respecto al resto de la comunidad, llegando a plantear que podrían constituir un indicio arqueológico de la presencia de esclavos y siervos (ROIG, 2015; VIGIL-ESCALERA, 2013). También se ha relacionado este tipo de inhumaciones con los contextos de abandono de dichos asentamientos, o bien se ha atribuido a acontecimientos excepcionales o traumáticos que implicarían la deposición apresurada de los cadáveres en determinadas estructuras de almacenamiento o de captación ya abandonadas, en un contexto temporal -finales del siglo VII e inicios del siglo VIII- en el que se están produciendo importantes cambios y transformaciones en el conjunto de Hispania (LÓPEZ, 2010: pp. 295296; GUTIÉRREZ, 2013: pp. 241-242).

Los registros de las estructuras tardovisigodas o de transición excavadas ofrecen otro dato de interés. La importante presencia de elementos constructivos de filiación romana en sus conjuntos materiales podría considerarse como un indicio del paulatino deterioro y desmantelamiento que habrían sufrido a lo largo del tiempo los espacios construidos de lo que pudo ser el núcleo habitado de la villa rustica, sin descartar que, aun con anterioridad, estos mismos espacios, ya abandonados, ya reorganizados, hubieran servido puntualmente como cantera para la formalización de algunas de las tumbas comprendidas en la necrópolis, teniendo en cuenta que los ladrillos utilizados en las mismas presentan idéntica modulación que los que se localizan en estructuras posteriores como material de desecho. De todos modos y como hemos dicho anteriormente, son los silos amortizados en la fase califal los que albergan la mayor parte de los restos constructivos secundarios que habrían sido utilizados en los alzados estructurales, cubiertas, pavimentaciones y revestimientos del hipotético núcleo residencial y administrativo del fundus agrícola ${ }^{14}$. Al no contar por el momento, y hasta que no se emprenda la correspondiente intervención de excavación, con ningún tipo de restos de las estructuras de hábitat asociadas a los espacios funerarios, es difícil establecer con exactitud el proceso que ha seguido el núcleo poblacional romano a lo largo de las diversas fases históricas estableciendo una conexión con los materiales constructivos desechados. No es descartable la posibilidad de que estos materiales constructivos hallados en los silos de almacenamiento posteriores al primigenio hábitat romano fueran reutilizados en las estructuras que formaban parte del asentamiento rural de época visigoda, un fenómeno que detectamos en la necrópolis, y que, de la misma manera que ocurre con el hábitat romano, aquél hubiese sufrido modificaciones y adaptaciones con la llegada de los nuevos pobladores musulmanes hasta quedar plenamente desmantelado y transformado en un nuevo núcleo habitacional de carácter islámico ${ }^{15}$.

La débil incorporación de elementos cerámicos islámicos en los contextos productivos tardovisigodos representados por el silo 2222/

14. El material constructivo romano consiste en material latericio diverso - ladrillos rectangulares de c. $29 \times 22 \times 7 \mathrm{~cm}$, laterculi, cuadrante de círculo-, tegulae e imbrices, en menor proporción placas de mármol, así como también un capitel realizado en calcarenita y el fuste de una columna de mármol.

15. Como testimonio del expolio al que habrían sido sometidos los restos del antiguo establecimiento romano, se ha localizado una estructura de cronología islámica con una acumulación o acopio intencional de ladrillos dispuestos de manera organizada, a modo 
E-1 nos lleva a intuir que, si bien la influencia de la presencia islámica se deja sentir desde momentos tempranos de la conquista $\left(1^{\mathrm{a}} \mathrm{mi}-\right.$ tad del siglo VIII), la implantación en el territorio de contingentes o grupos de pobladores musulmanes, al menos en nuestro marco de referencia espacial y así parece constatarse a nivel comarcal, ni fue mayoritaria, ni supuso importantes cambios en la estructura de poblamiento, siendo patente el predominio de la población autóctona frente al elemento minoritario árabe o bereber, este último prácticamente inexistente (GARCÍA, 2003: pp. 58-60, 164-166). La perduración de estas mismas unidades poblacionales hispano-visigodas durante la segunda mitad del siglo VIII y el siglo IX queda atestiguada en La Orden-Seminario gracias a la identificación de una fase de enterramientos emirales, entre los que aún se comprueba, en un conjunto con signos inequívocos de islamización religiosa, la pervivencia del rito cristiano. El bajo número de sepulturas de la fase emiral, así como su indefinición en términos espaciales, son asimismo características que comparte con la anterior necrópolis hispano-visigoda, lo que nos induce a pensar en un sistema social y productivo análogo, del que formarían parte un número muy reducido de grupos domésticos, quizás pertenecientes a un mismo grupo familiar, que podrían estar asociadas a formas de asentamiento del mismo rango.

Si la fase I de la necrópolis musulmana sugiere la posible extensión de la dinámica de ocupación tardoantigua en los inicios del dominio musulmán, con mayor seguridad se puede afirmar que constituye una prueba fehaciente de la temprana y rápida islamización de la población autóctona rural establecida en la zona onubense $\mathrm{e}^{16}$, lo que nos permite valorar positivamente la importancia del elemento muladí en el seno de la sociedad local ${ }^{17}$. El proceso de conversión al Islam queda reflejado en la adopción del rito funerario propiamente musulmán, y sobre todo en la casi generalización de una nueva posición de inhumación: el decúbito lateral derecho con la cara vuelta a la Meca, que se observa en cinco de las tumbas que componen la primera fase de la necrópolis. Sin embargo, como demuestra la sepultura 2566, nos encontramos aún en una etapa de transición ritual en la que coexisten en el mismo espacio funerario los ritos cristiano e islámico e, incluso, se mantiene la orientación visigoda de Este a Oeste, por otra parte, muy común en las primeras necrópolis andalusíes. Se ha sugerido que la convivencia de ritos en necrópolis de época islámica temprana obedece, al menos en los contextos rurales, a un fenómeno de conversión generacional, vinculado al ámbito familiar, en el que individuos emparentados no tienen problemas en compartir el espacio funerario con sus ascendientes consanguíneos, aun después de su conversión (GUTIÉRREZ, 2012: p. 197) ${ }^{18}$, siendo entendible, desde este punto de vista, el escaso peso otorgado a la segregación funeraria.

La idea de un rápido desarrollo de los procesos de islamización en el territorio de la Cora

de depósito-almacén, posiblemente para su reutilización posterior.

16. Desafortunadamente, no contamos con información suficiente procedente de otras necrópolis excavadas en el ámbito comarcal o provincial que permita extrapolar dichas apreciaciones. La necrópolis islámica denominada de "El Camino del Chorrito", localizada en el término municipal de Paterna del Campo, junto al castillo de Alpízar, es de las pocas que se conocen hasta la fecha en la provincia de Huelva, pero se corresponde con una población prealmohade, posiblemente del siglo XI, enterrada según el ritual coránico (MERCADO et alii, 2001). En el entorno del castillo se han documentado además los restos de una villa rustica romana que perduró como alquería en época islámica, habiéndose hallado en el mismo lugar una lápida funeraria del siglo VI (PÉREZ, 2004b: p. 95). Igual de interesante resulta la zona conocida con el nombre de "El Perú" en Bollullos par del Condado, donde las evidencias arqueológicas describen una amplia secuencia cultural que abarca desde el siglo IV hasta la Edad Media, comprendiendo un área de hábitat tardorromano asociada a una necrópolis del siglo VII (GARCÍA, 1997), y una posterior fase islámica almohade constituida por una alquería y su área funeraria (PÉREZ, 2003: p. 172; MALALANA, MORÍN y BARROSO, 2013: p. 343). En ambos casos, la secuencia observada a grandes rasgos bien podría reproducir el modelo que barajamos para contextualizar los restos de La Orden-Seminario.

17. En el ámbito periurbano de Huelva y siguiendo la propuesta de M. Acién que relaciona los topónimos de origen latino con compuestos en Munt con el poblamiento muladí, se ha mencionado como indicio de este tipo de poblamiento el topónimo Munt Lišam, qarya de la que procedía la familia del polígrafo cordobés Ibn Hazm, identificado con el cortijo de Montija próximo a La Orden-Seminario (PÉREZ, 2004c: p. 275).

18. Dicha aseveración se basa en los resultados de los análisis de ADN mitocondrial antiguo, efectuados sobre una amplia muestra de individuos de la necrópolis del yacimiento de Encadenado/El Soto (Madrid), donde se comprueba la existencia de lazos de paren- 
de Niebla, unidad administrativa a la que pertenecía el sector del núcleo onubense, se ve de entrada respaldada por el asentamiento de elementos y contingentes árabes-yemeníes en su demarcación desde el momento de la conquista, lo que, siendo estos los principales agentes sociales de la ideología dominante, debió favorecer la introducción de factores propicios a la aceleración del proceso (GARCÍA, 2003: p. 66; CAMPOS, GÓMEZ y PÉREZ, 2006: p. 359) 19 . Asimismo, la inhumación de rito cristiano documentada en esta primera fase de la necrópolis nos informa sobre la presencia en la etapa transicional del emirato de grupos mozárabes que conviven, como elementos sociales minoritarios del paisaje humano, en unos contextos de avanzada islamización, constituyendo uno de los pocos testimonios materiales hallados en la provincia de Huelva que avalan y complementan las diversas referencias textuales sobre la permanencia de comunidades cristianas en el territorio onubense con posterioridad a la conquista y hasta fechas tan avanzadas como mediados del siglo XII (GARCÍA, 2003: pp. 68-71) $)^{20}$.

Tras la fase funeraria emiral, se documenta una intensa fase agrícola en este sector del yacimiento que pone de manifiesto la existencia de un cambio en la forma en que se produce la explotación del espacio rural. La unidad estructural documentada con mayor profusión obedece a procesos finales de gestión y control de la producción agraria y consiste en silos excavados directamente en el terreno, con relación de superposición respecto a las tumbas, cuya cronología situamos en los siglos X y XI en atención a los materiales recuperados en sus rellenos de amortización ${ }^{21}$. El hecho de producirse esta reocupación de la zona sin respetar la integridad del área cementerial parece estar indicándonos que, presumiblemente, existió entre ambos momentos de ocupación un breve paréntesis o episodio de abandono, durante el cual es probable que la necrópolis hubiese perdido cualquier indicio de referencia visual o espacial, quedando finalmente enmascarada en un espacio desarticulado desde el punto de vista de su organización física y funcional.

La ruptura con la forma de poblamiento desarrollada en la fase emiral en La Orden-Seminario debió de producirse como consecuencia del proceso de centralización operado desde el poder omeya para la implantación del Estado califal andalusí en las primeras décadas del siglo $X$, uno de cuyos efectos fue la pérdida de poder de las élites muladíes locales, que controlaban el medio rural, y la desaparición de los elementos feudales heredados del mundo visigodo que caracterizaban el poblamiento en este medio. Este proceso, que M. Acién Almansa describe como el fracaso del "incastellamento" en su estudio sobre los rebeldes muladíes de Andalucía oriental (ACIÉN, 1998), permitió la emancipación del campesinado dependiente y condujo a la consolidación de la sociedad islámica en la que se impondrán nuevas formas de relaciones productivas en el ámbito de los contextos agrarios²2 (GARCÍA, 2003: pp. 84 y 165; PÉREZ, 2004c: p. 280). El hiato de poblamiento que proponemos, y que

tesco entre inhumados de distinto rito, cristiano e islámico (VIGIL-ESCALERA, 2009: p. 99; GUTIÉRREZ, 2012: pp. 196-197).

19. Planteamientos similares han sido valorados para determinar el favorecimiento de la islamización en las poblaciones locales de la Cora de Tudmir, en el sureste de al-Andalus (GUTIÉRREZ, 2007: p. 298).

20. Un testimonio excepcional de la pervivencia del culto cristiano durante el periodo andalusí es la campana mozárabe de bronce con inscripción cúfica hallada en Los Ronzones (Aljaraque) y depositada en el Museo Provincial de Huelva, que evidencia el mantenimiento de los espacios litúrgicos en el medio rural y la presencia de grupos cristianos arabizados hasta el siglo XI (BEDIA, BELTRÁN y LÓPEZ, 1992; MARTíNEZ, 2014: p. 70). Según el autor árabe al-Himyarī, que maneja fuentes de los siglos XI-XII, existía también en la ciudad de Huelva una gran iglesia muy venerada por sus habitantes debido a que supuestamente albergaba los restos de un apóstol (GARCÍA, 2002: p. 56).

21. En la documentación árabe el concepto de silo corresponde a los vocablos mațūra y hufra y se refieren a estructuras de tipo subterráneo. El geópono andalusí Ibn Bașsāa especifica que la huufra debía de ser profunda y alargada para el almacenamiento de cereales (MEOUAK, 2001: pp. 445-446), una morfología que no se observa en La Orden-Seminario.

22. Entre las modalidades contractuales por las que se rige la sociedad agrícola andalusí está el contrato de aparcería o mugārasa, del que tenemos constancia documental referida a la ciudad de Saltés, situada en la confluencia de los ríos Tinto y Odiel, para la época almorávide, referencia que demuestra la expansión de las formas de producción propiamente musulmanas en el espacio rural onubense (GARCÍA, 2001) 
parece detectarse en la secuencia estudiada, habría que relacionarlo por tanto con la caída del modelo hispano-visigodo de explotación del territorio y situarlo en el periodo de las revueltas que derivaron en la primera fitna en el Occidente de al-Andalus a finales del siglo IX, que supuso una seria amenaza para la estabilidad y continuidad del Estado omeya de Córdo$b^{23}$. La implantación definitiva en al-Andalus durante el califato de un modelo socio-económico estrictamente islámico y urbano derivó hacia una coyuntura de intensificación agrícola, cuyo pilar fundamental se apoyaba en una agricultura extensiva de base cerealista y con gran importancia del olivar. Para algunos investigadores, la continuidad de este contexto, unido a las mejoras en las técnicas de producción y al uso intensivo y racional de la tierra, supuso una verdadera revolución agrícola en el periodo de las taifas (MALALANA, MORÍN y BARROSO, 2013: pp. 337-339).

Si en otras regiones andalusíes se ha valorado la aparición del arcaduz como una manifestación de la adaptación a conjuntos tecnológicos vinculados con agrosistemas de regadío (GUTIÉRREZ, 1996), la ausencia de este particular elemento en La Orden-Seminario podría ofrecernos una lectura en positivo sobre las estrategias de explotación agraria desarrolladas en el ámbito territorial del yacimiento durante los siglos X-XI, las cuales tendrían su expresión más elemental en una agricultura extensiva de secano ${ }^{24}$. Pese a no contar con la presencia del arcaduz en nuestros registros, el resto de los repertorios cerámicos constituyen valiosos indicadores del amplio grado de asimilación de la cultura islámica por parte de la población indígena, y en definitiva de su completa islamización social. Las nuevas formas culinarias y de servicio de mesa, ya plenamente generalizadas e incorporadas como objetos de uso cotidiano, expresan la asunción de unos nuevos hábitos alimenticios y la extensión de unos procedimientos artesanales en el tratamiento cerámico (pintura, vidriado) perfectamente instalados en la vida material de las poblaciones califales del entorno rural onubense, un espacio que se nos muestra ya íntimamente interconectado con sistemas de producción y distribución de carácter urbano.

Tras la amortización de los silos y con posterioridad al siglo XI -fecha en la que nos sitúan los materiales más recientes recuperados en algunas de las subestructuras estudiadas- se constituye en las áreas contiguas al conjunto emiral un nuevo espacio funerario, cuyo momento de uso debemos situar en el periodo de dominio de las dinastías norteafricanas en al-Andalus, una etapa caracterizada a nivel ideológico por el rigorismo religioso y por la presión de las autoridades musulmanas sobre las minorías cristiana y judía (GARCÍA, 2004: pp. 40-41). En este sentido, uno de los aspectos relevantes que encontramos en los enterramientos de la fase II es la generalización del ritual funerario de acuerdo con la estricta aplicación de las normas y preceptos coránicos, lo que refleja, en términos de asimilación cultural, la plena islamización religiosa de la población inhumada. La ausencia de superposiciones entre las sepulturas de la última fase con respecto a la anterior, a pesar de la proximidad entre ambas áreas cementeriales, nos hace pensar que la localización del antiguo núcleo funerario habría sido reconocida durante esta fase final y consecuentemente respetada, de ahí que las nuevas sepulturas se instalaran y organizaran en ambas zonas adyacentes a aquél, preservándose incluso la continuidad espacial del conjunto.

El mayor número de sepulturas de la necrópolis de la fase II con respecto a la anterior nos informa, teniendo en cuenta el posible pe-

23. Las fuentes árabes ratifican la importancia y el protagonismo que adquirieron ciertos linajes muladíes onubenses en las sublevaciones contra el Emirato cordobés, los cuales acabaron todos sometidos a la autoridad de Abderramán III (GARCíA, 2003: pp. 73-82).

24. No es descartable, sin embargo, la existencia de terrenos de huerta y regadío en zonas de vaguada o cursos de agua cercanos, que por el momento no han sido documentados; así lo demuestran los registros palinológicos del horizonte islámico del citado Cabezo de la Almagra, donde los cultivos predominantes del olivo, de la vid y del trigo, éste último en retroceso en relación con la etapa romana, se compaginan con cierta horticultura de ribera (VIDAL et alii, 2008: p. 95). Por lo que respecta a la documentación escrita, los textos árabes se hacen eco de la abundancia del olivo y de la vid en el territorio de la Cora de Niebla, al tiempo que señalan la presencia de explotaciones hortícolas en los núcleos urbanos de Huelva y Saltés (GARCÍA,2002: p. 106; GARCÍA, 2003: pp. 183-184). 
riodo de uso de ambas, sobre un presumible incremento demográfico, indicativo de cambios en las estructuras social y productiva, que estaría asociado a la fundación de un núcleo rural de mayor entidad que el heredado de la antigua villa o pagus hispano-visigodo, el cual se correspondería con una alquería (qarya) o aldea, entendida esta como una entidad de poblamiento y de explotación dependiente de un centro urbano o núcleo castrense y base de la fiscalidad del Estado (GUICHARD, 1990-1991: pp. 197, 235). Las fuentes textuales dan cuenta de la abundancia y la importancia de los asentamientos rurales en el contexto de la Tierra Llana onubense y nos muestran una estructura de poblamiento fragmentada y dispersa, cuya expansión y definitiva consolidación parece haberse fraguado entre los siglos XII-XIII según algunas referencias tardías (GARCÍA, 2004: p. 45), un fenómeno que parece confirmarse, pese al estado incipiente de las investigaciones arqueológicas, a partir de los testimonios materiales (PÉREZ, 2013). Esta particularidad del poblamiento rural es extensible a todo el ámbito andalusí y se ha atribuido a la propia estructura clánica o tribal de las comunidades rurales que en momentos de crecimiento demográfico se verían obligadas a segmentarse con el objeto de optimizar los recursos económicos disponibles (GARCÍA, 2004: p. 45).

De otra parte, el estudio antropológico sugiere, al margen de la continuidad del sustrato poblacional autóctono, la existencia de elementos humanos foráneos en los que se observa una cierta influencia de población de origen africano, concretamente negroide o subsahariano, y nos plantea la posibilidad de valorar relaciones de mestizaje entre dichos elementos y el grupo autóctono mayoritario. Todo parece indicar que los individuos detectados se encontraban plenamente integrados en el tejido social de la comunidad, ya en cierto modo diversa, compartiendo el espacio funerario y coexistiendo bajo las mismas con- diciones de vida, sin que podamos determinar diferencias sociales por cuestiones étnicas ${ }^{25}$. Los rasgos no métricos observados en un número elevado de individuos testimonian, no obstante, que entre ellos debieron de existir vínculos de parentesco, por lo que podría tratarse de una comunidad en la que un gran número de personas compartían lazos familiares.

Las patologías reconocidas evidencian que la población estudiada pudo dedicarse a una actividad laboral que suponía importantes esfuerzos físicos, siendo compatible con una actividad agrícola continuada o, en cualquier caso, con hábitos posturales relacionados con movimientos forzados y reiterativos. Estas mismas patologías reflejarían asimismo una cierta diferenciación sexual del trabajo, teniendo en cuenta que son los hombres quienes presentan mayores indicadores de sobrecarga de tipo muscular. Otros datos obtenidos del estudio antropológico redundan en la idea de unas condiciones de vida adversas, o relativamente precarias: en algunos casos ponen en evidencia episodios de malnutrición para ciertos individuos, o de manera generalizada, nos informan sobre la dificultad de la población para acceder a una alimentación variada, aspectos ambos que son susceptibles de valorar en términos de desigualdad social. Aun así, se observa cierta evolución positiva con respecto a la fase anterior, dado que existe un mayor número de individuos que alcanzan la madurez.

En resumen, la información obtenida a través del estudio de los vestigios funerarios islámicos y otras estructuras de la fase medieval de la Orden-Seminario pone de manifiesto la continuidad del patrón de asentamiento rural disperso iniciado en época bajoimperial tras el declive de las zonas urbanas, constatado de forma generalizada en la denominada Tierra Llana de Huelva, al tiempo que ofrece datos precisos para el estudio de la evolución de estas poblaciones agrícolas durante el periodo

25. Según las fuentes jurídicas y formularios notariales, la mayor parte de la población negra andalusí (al-sudan) era de condición servil. Sin embargo, el derecho mālikí, preeminente en al-Andalus, favoreció la manumisión de los esclavos negros y la constitución de matrimonios mixtos, llegando a ejercer éstos, según la documentación escrita, diversas profesiones artesanales en las ciudades de Córdoba y Sevilla. En las cercanías de esta última ciudad, se localizaba una alquería cuyo nombre, qaryat al-sudan, revela la importancia de este grupo poblacional en el lugar (TAHIRI, 2003: pp. 47-48). 
de dominación musulmana, las cuales experimentan un proceso de islamización religiosa relativamente temprano y poco traumático, similar al que parece deducirse de los registros de algunas de las primeras maqbaras peninsulares (SERRANO et alii, 2016: p. 307). Dichas manifestaciones suponen un avance sustancial en el conocimiento arqueológico de este período, no solo por lo escaso de las evidencias materiales a nivel provincial, sino por la posibilidad que estas ofrecen para el análisis, en un mismo enclave, de los procesos socioeconómicos y culturales y su evolución en un momento de transición entre el mundo tardorromano y la incipiente ocupación musulmana y posterior islamización del territorio.

Quisiéramos concluir diciendo que el presente trabajo no pretende ser más que una pequeña aportación al conocimiento histórico-arqueológico del periodo medieval en la provincia de Huelva, cuya investigación es por el momento incipiente y fragmentaria. Teniendo en cuenta que algo más de la mitad del yacimiento de La Orden-Seminario se encuentra aún por intervenir, esperamos que futuras investigaciones aporten información suficiente para resolver algunas de las dudas y planteamientos aquí expuestos.

\section{BIBLIOGRAFÍA}

Acién Almansa, Manuel (1995): "Materiales e hipótesis para una interpretación del salón de Abd 'al-Rahman al-Nasir", Madinat al-Zahra. El Salón de Abd al-Rahman III. Córdoba, Junta de Andalucía, Consejería de Cultura y Medio Ambiente, 177-195.

Acién Almansa, Manuel (1998): "El final de los elementos feudales de al-Andalus: fracaso del <|ncastellamento $>$ e imposición de la sociedad islámica", L'Incastellamento: actas de las reuniones de Girona (26-27 noviembre 1992) y de Roma (5-7 mayo 1994). Roma, CSIC, Escuela Española de Historia y Arqueología en Roma, 291-305.

Acién Almansa, Manuel; Castaño Aguilar, José Manuel; Navarro Luengo, Ildefonso; Salado Escaño, Juan Bautista; Vera Reina, Manuel (2003): "Cerámicas tardorromanas y altomedievales en Málaga, Ronda y Morón", Cerámicas tardorromanas y altomedievales en la Península Ibérica. Ruptura y continuidad, Anejos de Archivo Español de Arqueología. XXVIII. Madrid, CSIC, 411-454.

Aguilar Moya, Laureano; González Rodríguez, Rosalía; Barrionuevo Contreras, Francisco José (1998): "El asen- tamiento islámico prealmohade de Jerez de la Frontera (Cádiz)", Spal. 7. Sevilla, Universidad, 163-173.

Alba CALZADO, Miguel A.; Feijoo martínez, Santiago (2003): "Pautas evolutivas de la cerámica común de Mérida en épocas visigoda y emiral", Cerámicas tardorromanas y altomedievales en la Península Ibérica. Ruptura y continuidad, Anejos de Archivo Español de Arqueología. XXVIII. Madrid, CSIC, 483-504.

Alba Calzado, Miguel A.; Gutiérrez Lloret, Sonia (2008): "Las producciones de transición al Mundo Islámico: el problema de la cerámica paleoandalusí (siglos VIII-IX)", Cerámicas hispanorromanas. Un estado de la cuestión. Cádiz, Universidad, 585-613.

Alba Calzado, Miguel A. (2005): "Dos áreas funerarias superpuestas, pagana e islámica, en la zona sur de Mérida", Mérida. Excavaciones Arqueológicas 2002. 8. Mérida, Consorcio Ciudad Monumental de Mérida, 309-342.

AMO, Mariano del (1976): Restos materiales de la población romana de Onuba, Huelva Arqueológica II. Huelva, Diputación Provincial.

Aran Herrera, Alba (2012): "La población de Marroquíes Bajos: reconstrucción de la vida biológica, social y cultural de la necrópolis musulmana de Jaén", Estrat Crític. 6. Bellaterra, Universidad Autónoma de Barcelona, 68-84.

Azuar Ruiz, Rafael, coord. (1989): La Rábita califal de las Dunas de Guardamar (Alicante): cerámica, epigrafía, fauna, malacofauna. Alicante, Museo Arqueológico.

Batanero Martín, Cristóbal Ignacio; Beltrán Pinzón, José Manuel; Vera Rodríguez, Juan Carlos (2016): "La necrópolis tardoantigua de La Orden-Seminario (Huelva): Rituales funerarios y aspectos antropológicos", Onoba: revista de Arqueología y Antigüedad. 4. Huelva, Universidad, 105126.

Bedia García, Juana; Beltrán Pinzón, José Manuel; López Domínguez, Miguel Ángel (1992): "La campana mozárabe del Museo Provincial de Huelva”, Cuadernos del Suroeste. 3. Huelva, Museo Provincial, 175-181.

Beltrán Pinzón, José Manuel (2005): "Registros cerámicos de época Taifa en madina labla (Niebla, Huelva): un acercamiento tipológico", Huelva en su Historia. 12. Huelva, Universidad, 53-76.

Benabat Hierro, Yolanda; Pérez Macías, Juan Aurelio (2003): "Apuntes sobre el ajuar cerámico del siglo XII en Niebla”, Arqueologia Medieval. 8. Porto, Ediçôes Afrontamento, 119-127.

Bermejo Meléndez, Javier; Campos Carrasco, Juan Manuel (2014): "El mundo tardorromano al occidente del Conventus Hispalensis. La transformación y ruptura del modelo clásico", Ciudad y territorio: transformaciones materiales e ideológicas entre la época clásica y el Altomedioevo, Monografías de Arqueología Cordobesa. 20. Córdoba, Universidad, 283-292.

Bernardes, Joâo Pedro; Viegas, Catarina (2016): "Roman amphora production in the Algarve (Southern Portugal)", Lusitanian Amphorae: production and distribution. Oxford, Archaeopress Archaeology, 81-92. 
Cano Piedra, Carlos (1996): La cerámica verde-manganeso de Madinat al-Zahra. Granada, Sierra Nevada 95.

CAMPOS CARRASCO, Juan Manuel (2005): Niebla, ciudad tartésica, romana y medieval. Huelva, Academia de Ciencias, Artes y Letras de Huelva.

Campos Carrasco, Juan Manuel (2009): Onoba Aestuaria. Una ciudad portuaria en los confines de la Baetica. Huelva, Ayuntamiento, Concejalía de Cultura.

CAMPOS CARRASCO, J. M.; GÓMEZ TOSCANO, F.; PÉREZ MACÍAS, J. A. (2006): Ilipla - Niebla. Evolución urbana y ocupación del territorio. Huelva, Universidad.

Carriazo Rubio, Juan Luis (2006): "Noticia decimonónica sobre una necrópolis romana y un tesorillo islámico en el Torrejón (Huelva)", Aestuaria: revista de investigación. 9. Huelva, Diputación Provincial, 207-216.

Casal, Ma . Teresa (2003): Los cementerios musulmanes de Qurtuba. Córdoba, Universidad.

Casal GARCíA, Ma Teresa; LEÓN MUÑOZ, Alberto; López, Rosa; Valdivieso Ramos, Ana; Soriano Castro, Patricio José (2006): "Espacio y usos funerarios en la Qurtuba islámica”, Anales de arqueología cordobesa. 17, 2. Córdoba, Universidad, 257-290.

Castillo Armenteros, Juan Carlos; Navarro Pérez, Mercedes; Serrano Peña, José Luis (2011): "Las Maqbaras de Marroquíes Bajos (Jaén) en torno al 711”, Zona Arqueológica: 711 Arqueología e Historia entre dos mundos. 15, I. Alcalá de Henares, Museo Arqueológico Regional, 273291.

Castillo Galdeano, Francisco; Martínez Madrid, Rafael (1993): “Producciones cerámicas en Bayyana”, La cerámica altomedieval en el sur de al-Andalus. Granada, Universidad, 67-116.

C.A.T.H.M.A. (1991): “ Importations de céramiques comunes méditerranéennes dans le midi de la Gaule (Ve-VIle s.)", A Cerâmica medieval no Mediterrâneo occidental. Mértola, Campo Arqueológico de Mértola, 27-47.

Cau Ontiveros, Miguel Ángel (2007): "Mediterranean late roman cooking wares: evidence from the Balearic Islands", LRCW 2. Late Roman Coarse Wares, Cooking Wares and Amphorae in the Mediterranean. Archaeology and Archaeometry, BAR International Series. 1662, I. Oxford, Archaeopres, 219-246.

CUESTA-GÓMEZ, J. Fabián; RAMOS, Tiago; PRATA, Sara (2018): "Empezar la casa por el tejado: las cerámicas de cobertura en los contextos altomedievales del territorio de Castelo de Vide (Portugal)", Cerámicas altomedievales en Hispania y su entorno (s. V-VIII D.C.). Valladolid, Glyphos, 137-158.

DE MIGUEL IBÁNEZ, María Paz; FONTECHA MARTíNEZ, Lara; IZAGIRRE ARRIBALZAGA, Neskuts; RÚA VACA, Concepción de la (2016): "Paleopatología, ADN y diferenciación social en la maqbara de Pamplona: límites y posibilidades", Demografía, paleopatologías y desigualdad social en el noroeste peninsular en época medieval. Bilbao, Universidad del País Vasco, 163-181.
Delgado Aguilar, Salvador (2016): Onoba Aestuaria, Memoria para optar al grado de doctor, bajo la dirección de los doctores Juan Manuel Campos Carrasco y Nuria de la O Vidal Teruel. Huelva, Universidad, Departamento de Historia I.

Delgado Molina, Pedro Ángel (2006): "Excavación de un área funeraria cristiana en época andalusí, Mérida. Excavaciones Arqueológicas 2003. 9. Mérida, Consorcio Ciudad Monumental de Mérida, 285-312.

Díaz, Eduardo (1921): "Herba, ciudad de Tartesos", Vell i Nou: revista d' art. 18. Barcelona, 194-199.

DU SOUICH, Philippe; RUIZ, Luis (1996): “'Había negroides en La Torrecilla?", Acta Historica et Archaeologica Mediaevalia. 16-17. Barcelona, Universidad, Facultad de Geografía e Historia, 295-297.

Fernández Guirado, Mª . Inés (1995): “La necrópolis musulmana de Yabal Faruh (Málaga)”, Estudios sobre cementerios islámicos andalusies. Málaga, Universidad, 37-69.

Fernández Rodríguez, Luis-Efrén; Salado Escaño, Juan Bautista; Suárez Padilla, José (2001): "Una nueva necrópolis hispanomusulmana de ámbito rural en el entorno de la Sierra de la Utrera (Málaga)", Cilniana. Revista de la Asociación Cilniana para la Defensa y Difusión del Patrimonio Cultural. 14. Marbella, Asociación Cilniana para la Defensa y Difusión del Patrimonio Cultural, 73-86.

Foy, D.; Picon, M.; Vichy, M.; Thirion-Merle, V. (2003): "Caractérisation des verres de la fin de l'Antiquité en Méditerranée occidentale: I'émergence de nouveux courants commerciaux", Échanges et commerce du verre dans le monde antique: Actes du colloque de l'Association Française pour I'Archéologie du Verre, Aix-en-Provence et Marseille, 7-9 juin 2001. Montagnac, Monique Mergoil, 41-78.

Fuertes Santos, Ma del Camino (2000): "La evolución de la cerámica medieval de Cercadilla, Córdoba. Estado de la cuestión", Anales de Arqueología Cordobesa. 11. Córdoba, Universidad, 217-232.

Fuertes Santos, Ma del Camino; González Virseda, Marina Leonor (1996): "Materiales de época emiral”, El criptopórtico de Cercadilla. Análisis arquitectónico y secuencia estratigráfica. Sevilla, Junta de Andalucía, 119-185.

Fuertes Santos, Ma . del Camino; Hidalgo Prieto, Rafael (2003): "Cerámicas tardorromanas y altomedievales de Córdoba", Cerámicas tardorromanas y altomedievales en la Península Ibérica. Ruptura y continuidad, Anejos de Archivo Español de Arqueología. XXVIII. Madrid, CSIC, 505540.

Fulford, Michael Gordon; Peacock, David P. S. (1984): Excavations at Carthage: The Bristih Mission I.2, The Avenue du President Habib Bourguiba, Salammbo. The pottery and other ceramic objects from the site. Sheffield, The British Academy.

García González, Francisco Manuel (1997): "Intervención arqueológica de urgencia en la necrópolis de El Lomo. Bollullos Par del Condado (Huelva)", Anuario Arqueológico de Andalucía / 1993, III Actividades de Urgencia. Sevilla, Junta de Andalucía, Consejería de Cultura, Dirección General de Bienes Culturales, 290-296. 
GARCíA SANJUÁN, Alejandro (2001): "Una fetua de época Almorávide sobre un pleito surgido en Saltés", Huelva en su Historia. 8. Huelva, Universidad, 391-401.

García Sanjuán, Alejandro (2002): La Huelva islámica, una ciudad del occidente de Al-Andalus (siglos VIII-XIII). Sevilla, Universidad, Ateneo de Sevilla.

García Sanjuán, Alejandro (2003): Evolución histórica y poblamiento del territorio onubense durante la época andaIusí (siglos VIII-XIII). Huelva, Universidad.

García Sanjuán, Alejandro (2004): "Huelva almohade en las fuentes escritas", Los Almohades: su patrimonio arquitectónico y arqueológico en el sur de al-Andalus. Sevilla, Junta de Andalucía, Consejería de Relaciones Institucionales, 35-55.

Gómez de la Torre-Verdejo, Amaya (2011): "La producción de vidrio en época visigoda: el taller de Recópolis”, Zona Arqueológica: 711 Arqueología e Historia entre dos mundos. 15, I. Alcalá de Henares, Museo Arqueológico Regional, 257-280.

Gómez Toscano, Francisco; Campos Carrasco, Juan Manuel (2001): Arqueología en la ciudad de Huelva (19962000). Huelva, Universidad.

González Fernández, Julián (2004): "Inscripciones cristianas de Bonares", Los Bojeos de Bonares y el Obispado visigodo de Niebla. Huelva, Diputación Provincial, 59-71.

González González, Borja; Linares Catela, José Antonio; Vera Rodríguez, Juan Carlos; González Batanero, Diego (2008): "Depotfund Zylinderförmigerldole des 3 jts. v. chr aus La Orden-Seminario (prov. Huelva)", Madrider Mitteilungen. 49. Madrid, Deutsches Archäologisches Institut, $1-28$.

GONZALO, J.; TRANCHO, G. J.; ROBLEDO, B. (2003): "Modificaciones intencionales de la corona dental: la mutilación dentaria”, ¿Dónde estamos? Pasado, presente y futuro de la paleopatología. Actas del VI Congreso Nacional de Paleopatología, (Madrid 13 al 16 de septiembre de 2001). Madrid, Universidad Autónoma de Madrid, Asociación Española de Paleopatología, 359-366.

Grilo, Carolina; Gómez Martínez, Susana; Marques, Joâo Antonio (2015): "Alqueva entre Roma e o Islâo: o povoamento rural na Antiguidade Tardia e no início da Época Islâmica", O sudoeste peninsular entre Roma e o Islâo. Southwestern iberian península between Rome and Islam. Mértola, Campo Arqueológico de Mértola, 188-243.

Guichard, Pierre (1990-1991): Les Musulmans de Valence et la Reconquête (XIe-XIIle siècles). Damasco, Institut Français, 2 vols.

Gutiérrez Lloret, Sonia (1986): "Cerámicas comunes altomedievales: contribución al estudio del tránsito de la antigüedad al mundo paleoislámico en las comarcas meridionales del País Valenciano", Lucentum. 5. Alicante, Universidad, 147-167.

Gutiérrez Lloret, Sonia (1993): "La cerámica paleoandalusí del sureste peninsular (Tudmir): producción y distri- bución (siglos VII al X)", La cerámica altomedieval en el sur de al-Andalus: primer encuentro de Arqueología y Patrimonio. Granada, Universidad, 37-65.

Gutiérrez Lloret, Sonia (1996): "El aprovechamiento agrícola de las zonas húmedas: la introducción del arcaduz en el sureste de al-Andalus (siglos VIII y IX)", Arqueología y territorio medieval. 3. Jaén, Universidad, 7-19.

Gutiérrez Lloret, Sonia (2007): "La islamización de Tudmir: balances y perspectivas", Villes et campagnes de Tarraconaise et d'al-Andalus (Vle-Xlesiècles): la transition. París, Centre National de la Recherche Scientifique, 275-318.

Gutiérrez Lloret, Sonia (2012): "El reconocimiento arqueológico de la islamización. Una mirada desde al-Andalus", Zona Arqueológica: 711 Arqueología e Historia entre dos mundos. 15, I. Alcalá de Henares, Museo Arqueológico Regional, 190-210.

GUTIÉRREZ LLORET, Sonia (2013): "De Teodomiro a Tudmir. Los primeros tiempos desde la arqueología (s. VIIIX)", De Mahoma a Carlomagno: los primeros tiempos (siglos VII-IX), XXXIX Semana de Estudios Medievales, Estella, 17-20 de julio de 2012. Pamplona, Gobierno de Navarra, 229-283.

Jiménez Martín, Alfonso (1991): "La qibla extraviada", Cuadernos de Madinat al-Zahra: Revista de difusión científica del Conjunto Arqueológico Madinat al-Zahra. 3. Córdoba, Junta de Andalucía, Conserjería de Cultura, 189-209.

López Flores, Inmaculada (2006): Informe Antropológico de los restos procedentes de la Intervención Arqueológica Sector 8 (Seminario) de Huelva 2005. Huelva. Inédito.

López Flores, Inmaculada (2009): Base de datos antropológica PP8 "Seminario" Huelva. Huelva. Inédito.

López Quiroga, Jorge (2010): Arqueología del mundo funerario en la Península Ibérica (siglos V-X). Madrid, Ergástula.

Macias I Solé, Josep María (2003): "Cerámicas tardorromanas de Tarragona: economía de mercado versus autarquía", Cerámicas tardorromanas y altomedievales en la Península Ibérica. Ruptura y continuidad. Anejos de Archivo Español de Arqueología. XXVIII. Madrid, CSIC, 21-39.

Maestre Borge, Cinta (2012): "La cerámica común tardía en Sevilla (siglos IV-VI)", Cerámicas hispanorromanas II: producciones regionales. Cádiz, Universidad, 487-510.

Maestre Borge, Cinta; García Vargas, Enrique; Vázquez Paz, Jacobo; García García, Miguel Ángel (2010): "Contextos de mediados del siglo VI d.C procedentes de la colmatación de una cisterna romana de Hispalis (Sevilla, España)", LRCW3. Late Roman coarse wares, cooking wares and amphorae in the Mediterranean. Archaeology and archaeometry. Comparison between western and eastern Mediterranean, BAR International Series. 2185, I. Oxford, Archaeopress, 183-192.

Malalana Ureña, Antonio; Morín de Pablos, Jorge; Barroso Cabrera, Rafael (2013): "Acerca de la funcionalidad de los denominados silos-basureros: una propuesta metodológica para el estudio de la agricultura andalusí en época califal y taifa", Archeologia Medievale. XL. All'Insegna del Giglio, 337-352. 
Martínez Núñez, Mª Antonia (2014). “Las fuentes epigráficas. Siglos IX-X”, Jábega. 105. Málaga, Diputación Provincial, 59-73.

Mattei, Luca (2014): "Poblado y necrópolis mozárabe del conjunto arqueológico de Tózar. Un proyecto de investigación y puesta en valor", Debates de Arqueología Medieval. 4. Granada, Universidad, 181-196.

Mayet, Françoise; Tavares da Silva, Carlos (2016): "Roman amphora in the lower Sado region", Lusitanian amphorae: production and distribution. Oxford, Archaeopress Archaeology, 59-71.

Meouak, Mohamed (2001): "Graneros y silos en las fuentes árabes del occidente islámico medieval", Anaquel de estudios árabes. 12. Madrid, Universidad Complutense, 443-448.

Mercado Hervás, Laura; Caravaca Rodríguez, Carmen; Paz Jorva, Manuel Jesús; Gasent Ramírez, Rosario (2001): "La necrópolis hispano-musulmana de El Camino del Chorrito, Paterna del Campo, Huelva", Anuario Arqueológico de Andalucía / 1998, III Actividades de Urgencia, vol. 1. Sevilla, Junta de Andalucía, Consejería de Cultura, 388-393.

Moreno Garrido, Ma . Jesús (1987): "La cerámica de cuerda seca peninsular: origen y dispersión”, // Congreso de Arqueología Medieval Española. III. Madrid, Comunidad de Madrid, Dirección General de Patrimonio Cultural, 33-42.

Motos Guirao, Encarnación (1993): "La cerámica altomedieval de El Castillón (Montefrío, Granada)”, La cerámica altomedieval en el sur de al-Andalus. Granada, Universidad, 207-237.

O 'Kelly Sendrós, Jessica (2012): "Las ánforas onubenses de época tardorromana", Cerámicas hispanorromanas II: producciones regionales. Cádiz, Universidad, 279-295.

Olmo Enciso, Lauro (1986a): "Cerámica común de época hispanomusulmana en Niebla", I/ Coloquio Internacional de Cerámica Medieval en el Mediterráneo Occidental. Madrid, Ministerio de Cultura, Subdirección General de Arqueología y Etnología, 135-139.

Olmo Enciso, Lauro (1986b): "Nuevos datos para el estudio del asentamiento hispanomusulmán de Mesas de Asta (Jerez de la Frontera. Cádiz)", Actas del I Congreso de Arqueología Medieval Española. IV. Zaragoza, Asociación Española de Arqueología Medieval, 229-242.

Pérez Alvarado, Sonia (2003): Las Cerámicas omeyas de Marroquíes Bajos (Jaén): un indicador arqueológico del proceso de islamización. Jaén, Universidad.

Pérez Macías, Juan Aurelio (2003): "La alquería de Los Parrales (San Juan del Puerto, Huelva)", Huelva en su Historia. 10. Huelva, Universidad, 169.176.

Pérez Macías, Juan Aurelio (2004a): "Los Bojeos", Los Bojeos de Bonares y el Obispado visigodo de Niebla. Huelva, Diputación Provincial, 11-58.

Pérez Macías, Juan Aurelio (2004b): "Arqueología del Cristianismo primitivo en Huelva”, Ave verum corpus. Cristo eucaristía en el arte onubense. Córdoba, Cajasur, 79-107.

Pérez Macías, Juan Aurelio (2004c): "Poblamiento y explotación en el Suroeste de al-Andalus", Paisaje y naturaleza en al-Andalus. Granada, Fundación El Legado Andalusí, 269-290.
Pérez Macías, Juan Aurelio (2013): “El asentamiento rural almohade de la Alquería (Hinojos, Huelva)", VI Encuentro de Arqueología del Suroeste Peninsular. Villafranca de los Barros, Ayuntamiento, 2053-2072

Pérez Macías, Juan Aurelio; Vidal Teruel, Nuria de la O; De Haro Ordónez, Jesús (2001): "Intervención arqueológica de urgencia en la barriada de La Orden (Huelva)", Anuario Arqueológico de Andalucía / 1998, III Actividades de Urgencia, vol. 1. Sevilla, Junta de Andalucía, Consejería de Cultura, 377-380.

Polo Cerdá, Manuel; López Florez, Inmaculada (2009): "Encondromas en tres necrópolis del Levante y Sur peninsular", Investigaciones Histórico-Médicas sobre salud y enfermedad en el pasado, Actas del IX Congreso Nacional de Paleopatología Morella (Castelló), 26-29 septiembre de 2007. Valencia, Grupo Paleolab \& Sociedad Española de Paleopatología, 319-324.

Poveda Navarro, Antonio M.; Peidro Blances, Jesús (2007): "Cerámicas tardorromanas y altomedievales en el Monastil (Ello), Elda, Alicante", Estudios de cerámica tardorromana y altomedieval. Salobreña, Alhulia, 319-355.

Pozo Martínez, Indalecio; Hernández Carrión, Emiliano (1999): "El conjunto arqueológico de la Rinconada de Olivares, Jumilla", Memorias de Arqueología 1994. 9. Murcia, Instituto de Patrimonio Histórico, Editora regional de Murcia, 416-429.

Ramos, Ana Cristina; Laço, Teresa.; Almeida, Rui; Viegas, Catarina (2007): "Les céramiques communes du Vie siécle du complexe industriel de salaisons de poissons de Lagos (Portugal)", LRCW 2. Late Roman Coarse Wares, Cooking Wares and Amphorae in the Mediterranean. Archaeology and Archaeometry, BAR International Series. 1662, I. Oxford, Archaeopres, 85-97.

Retuerce Velasco, Manuel (1998): La cerámica andalusí de la Meseta. Madrid, Marcial Pons, 2 vols.

Reynolds, Paul (1985): "Cerámica tardorromana modelada a mano de carácter local, regional y de importación en la provincia de Alicante", Lucentum. IV. Alicante, Universidad, 245-267.

Rius, Monica (2000): La Alquibla en al-Andalus y al-Magrib al-Aqsà. Anuari de Filologia (Universitat de Barcelona) XXI (1998-99) B-3. Barcelona, Institut "Millás Vallicrosa" d'Historia de la Ciencia Arab.

Roig Buxó, Jordi (2011): "Formas de poblamiento rural y producciones cerámicas en torno al 711: documentación arqueológica del área catalana", Zona Arqueológica: 711 Arqueología e Historia entre dos mundos. 15, II. Alcalá de Henares, Museo Arqueológico Regional, 119-144.

Roig Buxó, Jordi (2015): "Necrópolis de época visigoda, ajuares funerarios y depósitos humanos anómalos de los s. V-VIII en la Tarraconense oriental (Cataluña): ¿indicadores de "etnicidad" y/o nivel económico? e indicios arqueológicos de desigualdad y exclusión social", Identidad y etnicidad en Hispania. Propuestas teóricas y cultura material en los siglos V-VIII. Bilbao, Universidad del País Vasco, pp. 334-393.

ROMÁN MUÑOZ, Carmen María (2013): "Análisis antropológico de un grupo poblacional que vivió en Madinat 
Ilbira", Arqueología y Territorio. 10. Granada, Universidad, 141-159.

Rosselló Bordoy, Guillermo (1978): Ensayo de sistematización de la cerámica árabe en Mallorca. Palma de Mallorca, Diputación Provincial de Baleares.

Ruiz Acevedo, Juan Manuel (1998): Las vías romanas en la provincia de Huelva. Huelva, Diputación Provincial.

Ruiz Nieto, Eduardo (2001): "Representaciones antropomórficas hispanomusulmanas sobre hueso", Anales de Arqueología Cordobesa. 12. Córdoba, Universidad, 385-396.

Sánchez Pravia, José; Gallego Gallardo, Juana; Bernal Pascual, Francisca (1987): "Una necrópolis musulmana en el Cabezo del Aljezar (Ricote, Murcia)", Il Congreso de Arqueología Medieval Española. III. Madrid, Comunidad de Madrid, Consejería de Cultura, 149-156.

Sánchez Sánchez-moreno, Vicente M.; Galindo San José, Lorenzo (2006): "Cabañas con cubierta de teja en el yacimiento arqueológico de Frontera de Portugal", Zona Arqueológica: La investigación arqueológica de la época visigoda en la Comunidad de Madrid. La ciudad y el campo. 8, I. Alcalá de Henares, Museo Arqueológico Regional, 471-478.

SERRANO HERRERO, Elena; TORRA PÉREZ, Mar; CATALÁN RAMOS, Raúl; VIGIL-ESCALERA GUIRADO, Alfonso (2016): "La cerámica de los siglos VIII-IX en Madrid, Toledo y Guadalajara", La cerámica de la Alta Edad Media en el cuadrante noroeste de la Península Ibérica (siglos V-X). Sistemas de producción, mecanismos de distribución y patrones de consumo, Bilbao, Universidad del País Vasco, 279-313.

Serrano Peña, José Luis; Castillo Armenteros, Juan Carlos (2000): "Las necrópolis medievales de Marroquíes Bajos (Jaén). Avance de las investigaciones arqueológicas", Arqueología y territorio medieval. 7. Jaén, Universidad, 93120

Suárez Padilla, José; Navarro Luengo, Ildefonso; Soto Iborra, Antonio; Fernández Rodríguez, Luis Efién; Santamaría García, José Antonio; Sánchez Herrera, José Manue (1999): "La excavación arqueológica de urgencia en el yacimiento de La Caserona. Cortijo de San Eugenio (Teba, Málaga). C-341, Ardales-Campillos. PK 11,680", Anuario Arqueológico de Andalucía / 1995, III Actividades de Urgencia. Sevilla, Junta de Andalucía, Consejería de Cultura, 430-438

TAHIRI, Ahmed (2003): Las clases populares en al-Andalus. Málaga, Editorial Sarriá.

TEJERIZO GARCíA, Carlos (2016): "Construyendo la casa por los cimientos: consideraciones acerca de la cerámica de la primera Alta Edad Media en la parte central de la cuenca del Duero", La cerámica de la Alta Edad Media en el cuadrante noroeste de la Península Ibérica (siglos V-X). Sistemas de producción, mecanismos de distribución y patrones de consumo, Bilbao, Universidad del País Vasco, 229-254.

Tendero Porras, Eva; Gilabert Mas, Antonio; Olcina Doménech, Manuel (2007): La maqbara del Tossal de Manises (Alicante). Alicante, Museo Arqueológico Provincial, 2 Vols.
TENTE, Catarina; DE MAN, Adriaan (2016): "Um rio, dois territórios no centro de Portugal. A produçao cerámica no vale do Mondego - os casos do espaço rural do Alto Mondego e de Conimbriga", La cerámica de la Alta Edad Media en el cuadrante noroeste de la Península Ibérica (siglos V-X). Sistemas de producción, mecanismos de distribución y patrones de consumo, Bilbao, Universidad del País Vasco, 43-68.

Vallejo Triano, Antonio; Escudero Aranda, José (1999): "Aportaciones para una tipología de la cerámica común califal de Madinat al-Zahra", Arqueología y Territorio Medieval. 6. Jaén, Universidad, 133-176.

Vera Rodríguez, Juan Carlos; Linares Catela, José Antonio; Armenteros Lojo, Ma ${ }^{a}$. José; González Batanero, Diego (2010): "Depósitos de ídolos en el poblado de La Orden-Seminario de Huelva: Espacios rituales en contexto habitacional", Ojos que nunca se cierran. Ídolos en las primeras sociedades campesinas. Madrid, Ministerio de Cultura, 199-242.

Vidal TERUEL, Nuria de la O; Gómez RODRÍGUEZ, Águeda; Campos CARRASCO, Juan Manuel (2003): "El entorno rural del núcleo urbano de Huelva en la Antigüedad y la Edad Media: la villa de La Almagra", Bolskan: Revista de arqueología del Instituto de Estudios Altoaragoneses. 20. Huesca, Instituto de Estudios Altoaragoneses, 325333.

Vidal Teruel, Nuria de la O; Campos Carrasco, Juan Manuel; Gómez Rodríguez, Águeda; Sánchez Hernando, Luis Javier (2008): "Arqueología rural islámica en Huelva: la alquería de la Almagra”, Arqueologia medieval. 10. Mértola, Campo Arqueológico de Mértola, 65-104.

Vidal Teruel, Nuria de la O; Campos Carrasco, Juan Manuel; Gómez Rodríguez, Águeda; Sánchez Hernando, Luis Javier (2013): "El mundo rural en el entorno de Huelva desde la Antigüedad hasta el mundo contemporáneo: el cabezo de la Almagra", Arqueología en la provincia de Huelva: homenaje a Francisco Javier Rastrojo Lunar. Huelva, Universidad, 176-205.

Vigil-Escalera Guirado, Alfonso (2003): "Cerámicas tardorromanas y altomedievales de Madrid", Cerámicas tardorromanas y altomedievales en la Península Ibérica. Ruptura y continuidad, Anejos de Archivo Español de Arqueología. XXVIII. Madrid, CSIC, 371-387.

Vigil-Escalera Guirado, Alfonso (2013): "Comunidad política aldeana y exclusión. Una revisión de las formas de inhumación altomedievales (ss. V-VIII d.C.)", Retti Medievali Rivista. 14, 1. Firenze, Firenze University Press, 3-42.

Vigil-Escalera Guirado, Alfonso (2009): "Sepulturas, huertos y radiocarbono (siglos VIII-XIII D.C.). El proceso de islamización en el medio rural del centro peninsular y otras cuestiones", Studia historica. Historia medieval. 27. Salamanca, Universidad, 97-118.

Vigil-Escalera Guirado, Alfonso (2015): "La identidad de la comunidad local y las afiliaciones individuales en necrópolis de la Alta Edad Media (400-900 AD)", Identidad y etnicidad en Hispania: propuestas teóricas y cultura material en los siglos V-VIII. Bilbao, Universidad del País Vasco, 249-274. 
